\title{
A LUTA PELA IMPLANTAÇÃO DE UMA ÁREA VERDE URBANA DENTRO DE UMA PROPOSTA DE EDUCAÇÃO AMBIENTAL: ESTUDO DE CASO NO MUNICÍPIO DE VOTORANTIM (SP)
}

ADRIANO LOPES PEREIRA DE MELO

Engenheiro Florestal

Orientador: Prof. Dr. MARCOS SORRENTINO

Dissertação apresentada à Escola Superior de Agricultura "Luiz de Queiroz", Universidade de São Paulo, para obtenção do título de Mestre em Ciências, Área de concentração: Ciências Florestais.

P I R A C I C A B A

Estado de São Paulo - Brasil

Fevereiro - 2000 


\title{
Dados Internacionais de Catalogação na Publicação (CIP) DIVISÃO DE BIBLIOTECA E DOCUMENTAÇÃO - Campus "Luiz de Queiroz"/USP
}

Melo, Adriano Lopes Pereira de

A luta pela implantação de uma área verde urbana dentro de uma proposta de educação ambiental: estudo de caso no municipio de Votorantim (SP) / Adriano Lopes Pereira de Melo. - - Piracicaba, 2000.

$198 \mathrm{p}$.

Dissertação (mestrado) - - Escola Superior de Agricultura Luiz de Queiroz, 2000. Bibliografia.

1. Ambiente urbano 2. Área urbana 3. Cidadania 4. Educaçāo ambiental 5. Movimento ecológico 6. Política pública 1. Titulo

\author{
CDD 333.707
}


- PAG.I -20 PARÁGRAFO-3゚ LINHA - code lè-se tên" leia-se tem"

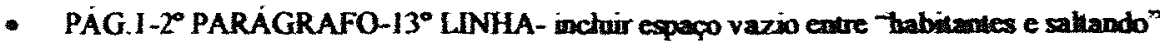

- PÁG.2-20 PARÁGRAFO:-2 LINHA-alterar para "na época desse estudo" (realicado pela 1993 pela Prefeitura Municipal de Votoramim)

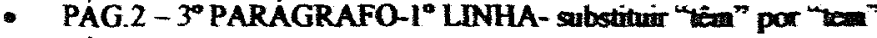

- PÁG.5 - 8. LNHA - suprivuir una vígula depois da palavra -ivea"

- PÁG9-7 LINHA - soprisiir a letra "e" após o parèntese

- PAG.9 - hem Objetivo Geral: grafia incorrela - sobstituir "participativos" per "participativos"

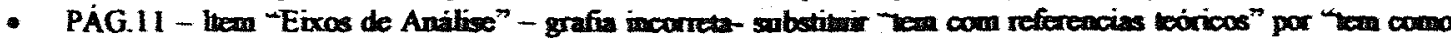
referenciais teóricos"

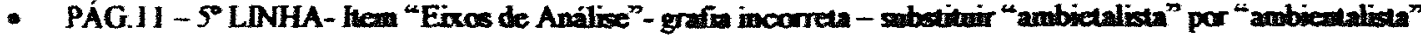

- PÁG.12 - 2 LINHA - grafa incorreta - substitair - molhidensicmalidade" par "maltidimensionalidade"

- PÁG.12-4" LINHA - grafía incarreta - substitur "usulirren fexctidade" par "moltirreferencialidade"

- PAG.14 - 10 LINHA - substitur "cita do" por cita o"

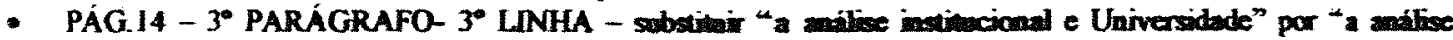
institucional da Universidade"

- PÁG.17 - 1' PARÁGRAFO - T LINHA - inchair (1971) após Fraror

- PÁG.17 - Z PARÁGRAFO- Akerar para Fistead (1971)

- PÁG.17 - $3^{\circ}$ PARÁGRAFO - betuir (1974) após Mbrray et a

- PAG.19-1०LNHA - sabetituir o ponto por vígnila após o parizase

- PÁG.19-2 LINHA - grafia incometa - sobstituir "experencinf por "experiencial"

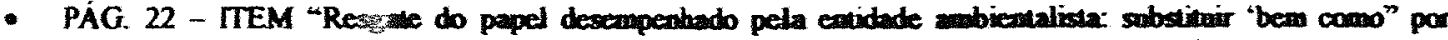

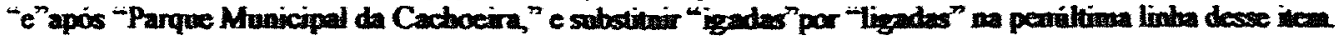

- PÁG. 28 - 20 PARÁGRAFO - 6 LINHA - suprimir "como" e inchir vingula após "considerado"

- PÁG. 32 - 10 LINHA - grafia incorreta-substituir "us"por "mapós a palavra "alleraçöes"

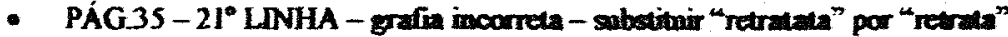

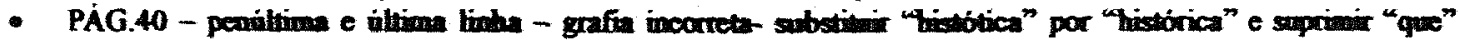
após "cilada"ma nitima linha.

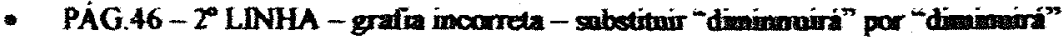

- PÁG.49 - 30 PARÁGRAFO - 80 LNHA - soprienir uma virgala após "projedo"

- PÁG 51 - 4' PARAGRAFO - T LINHA - suprimir "anexo" após -301290"

- PÁG.53 - 3० PARAGRAFO - 70 LINHA - data correta é "27/2/25"

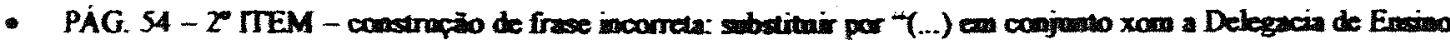

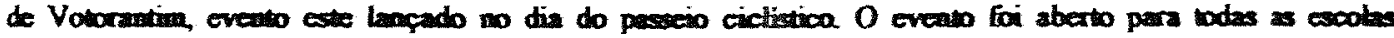

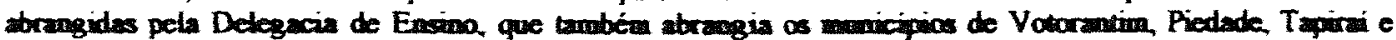
Sallo de Pirapara. com cerca de 15.000 alunos."

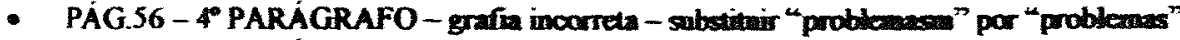

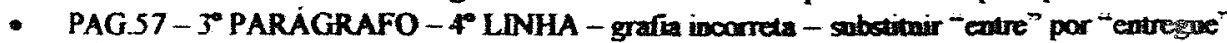

- PAG.64 - TEM 33 - Inclurir. As entrevistas com os ex-integrates faran feitas no final de 97 e durante 0 ano de 94. expanto pae com os ex-prefeitos no fenal do ano de 1999 (moveabro e dezembro).

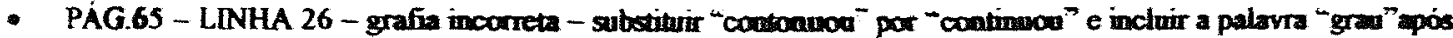
$-1^{\text {on }}$

- PÁG.69 - LINHA 14 - substibuir o entrevistado "L " por - L.J."

- PÁG.69-LINHA 19 - grafía incurreta - substituir "por por -pós-

- PÁG.71 - LINHA 20 - grafia incarreta - sabstituir "apb" por "sob"

- PAG.73 - LINHA 8 - substituir o entrevistado - L." por -LJ."

- PAG.73 - LINHA 13 - grafia incorreta - substimir "apresentacican" por "apresentaçä"

- PÁG.73 - LINHA 25 - grafia incorreta - substituir "puxão d crel "por "puxão de orella"

- PAG.8I - LDNHA 2 - grafia incorrea - substituir -fáceia por - faces

- PAG.81 - LINHA 12 - grafia incorrea - substituir fala"por "faha"

- PAG.83 - LINHA 4 - substituir-1993"por-1983"

- PÁG.84 - LINHA 1 - suprimir -Anexo 2"

- PAG.87- 20 PARAGRAFO - LNHA 5 - substiúr " na qual por - no qual

- PAG. 87 -2 PARAGRAFO - LINHA 8 - grafia incortea - sabstituir -enpresa"por "empresa

- PAG. 87 - 4'PARAGRAFO - LINHA 2-grafa incorrela - sobetituir -relativos" por "rebativas"

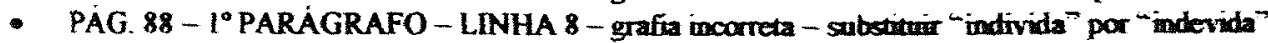




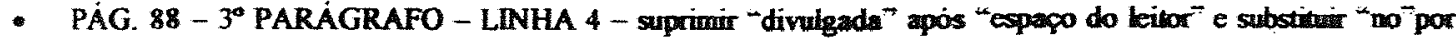
nos"

- PAG. 90-LINHA 5-substitui "pode" por "podexa"

- PÁG.90-2 PARÁGRAFO - substivirir "destaca-se" por "aponta-se"

- PÁG.92 - 30 PARAGRAFO - LINHA 7 - incluir a palavra "ärea após sem formaçä

- PAG.93 - ITEM 6 - LINHA 2 - colocar no phural: "en relacão problomas existcales"

- PÁG. 98 - PENÚLTTMA LINHA - grafia incorreta - sabstituir "laze” por "laner"

- PÁG. 102 - LINHA I-grafia incorreta - substituir" "ar" por "a"

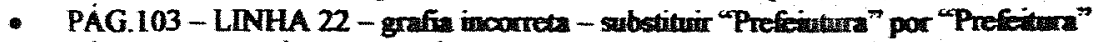

- PÁG.105 - PENÚL TMMA E ÚLTMA LINHA - substituir "os mesmos "por "o mosmo"

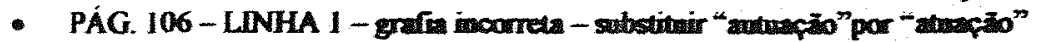

- PÁG. 106-1" PARÁ GRAFO - LNHA 5-grafi incorret - sabstidsir "comodata" por "conodato"

- PAG.108 - 2" PARÁGRAFO - LINHA 3 - substituir "polipubileno" por "potipropileno"

- PÁG. 109 -LINHA 16 - grafí incorreta-sabstituir "vsetigio" por "vestigios"

- PAG. 110-LNNHA 11 - grafi incorrea - sabstuir "fizess" por "fizesse"

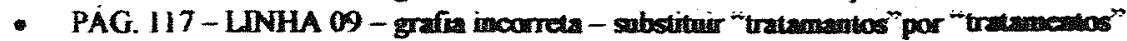

- PÁG. 118 - LINHA 3-grafm imcorreta - sabstivir "que” por "quea"

- PÁG.119 - LINHA 3 - grafia incorreba - substituir "dabia" par "sabia"

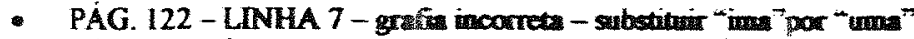

- PÁ.124 - ULTIMA LINHA- substituir "e situacido" por -e cita"

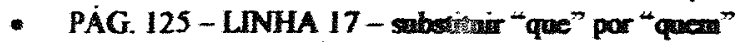

- PÁG.125 - 4" PARAGRAFO - allerar a colocacão do "a" para depois da palavra "proceder"; inserir was espaco

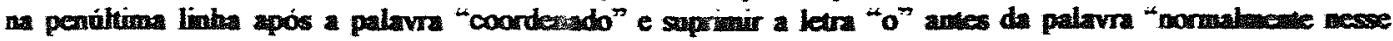
mesina linka.

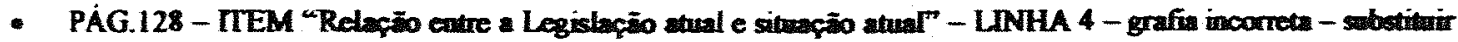
"pobre" por "pobres".

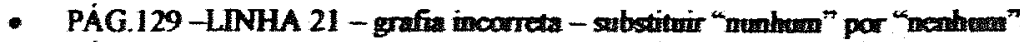

- PÁ. 130 - LINHA 26 - grafia incorreta - substituir "Lutzem Berger" por -Lutzemberger"

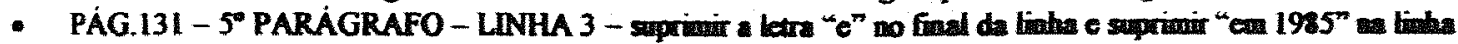
4.

- PÁG. 133 - LINHA 2 - grafia incorreta - substituri "fasean" por "frase"

- PÁG.133 - LINHA 8 - grafia incarreda - substituir "process" por "processo"

- PAG.134 - 20 PARÁGRAFO - LINHA 6 - sabstituir "inseridos" por -inserido"

- PÁG.134 - 30 PARÁGRAFO - LINHA 2 - grafin incorret - substiturir "eatidadades" por "extidades"

- PAG. $134-5^{\circ}$ PARAGRAFO - LINHA 2-surimin -

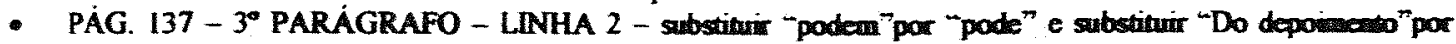
-Das depoinemas"

- PÁ. 138-1" PARÁGRAFO - LINHA 4-grafia incorrct - substituir "sócias" por “sociais"

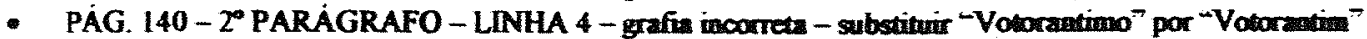

- PAG.140 - 3० PARÁGRAFO - rearranjar parte do paragrafo como: -Ferreira (1998) citou com base em

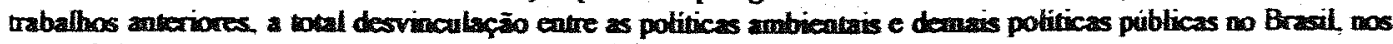
miveis federal e estadud"

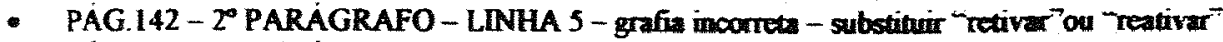

- PÁG.142 - 5 PARÁRAFO-LINHA I - saprimir a palavra -de”

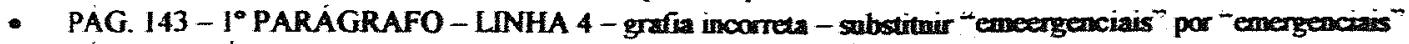

- PÁ. 143 - ÚLTTMA LINHA - grafia incorreta - substituir -equaibrio por "equilibrio"

- PAG. 144 - inserir parágrafo no final: -Por vuntade potitica o autor entende como sendo a iniciativa do poder publico capitaneada peto Prefeito em implencatar medidas e projetos de interesse social ou ambiental com base en compronissos assumidos e con atendimento as demandas (sociais, ambientais) de grupos organizados e da sociedade en geral. criando condicöes en termos de recursos materiais e humanos para a efetivacäo dessas medidas e propostas

- PAG. 145 - 2 PARAGRAFO - LINHA 6 - substiturir "a por "as"

- PÁ. 145 - ÚLTIMA LINHA - substituir as necessarias por -os nocessarios

- PAG. 146 - LINHA 8 - grafia incorreta - sabstituir -aprefeipaado"por-aperfeicoado"

- PAG. 146-2 PARÁGRAFO - LINHA 5 - saprimir -for

- PÁG. 170 - LINHA 1 - suprimir espaco incxistente dentro da palavra teatratizaçá-

- PAG. 176-PENÚLTIMA LINHA - supriarir -já houve-

- PÁG. 177 - LINHA 1 - substituir -a" por hà

- PAG. 177 - LINHA 5 - sabstituir -a" por thá 
- PAG. 177 - LINHA 9- substituir "a" por "ha"

- PÁG. 177 - ULTIMA LNHA - supvimir - na forma de painées"

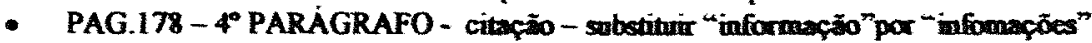

- PÁ. 178 - $5^{\circ}$ PARAGRAFO - LINHA 2 - substituir "lem sendo" por vên sendo"

- PAG. $179-3^{\circ}$ IEM - substituir entorno" por -em torno"

- PÁG. 180-TEM 1-LNHA 2-grafa incurrela-substitair "inclusivem" por "inchesive"

- PÁG. 180-ITEM 1 - LINHA 4-substituir "entomo" por "em tromo"

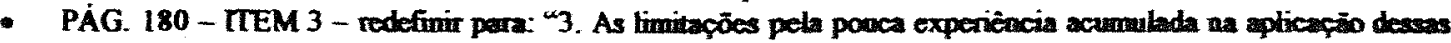
tecricas em nosso meia, longe de serem enxergadas como obsticulos, devem servir como estirnib para o aprofandamento no estudo e aplicapäo das mesmas."

- PAG. 181 - Redigir o primeiro parágrafo: uPor um percurso tortuoso, procaramos buscar respostas aos questionamentos a respeito do papel das pequenas entidades ambicatalistas e à possibilidade da implantacio de espapos hives de uso público como um instrumento de educação ambiental e ao papel do poder público mesce contexto." 


\section{SUMÁRIO}

Página

RESUMO

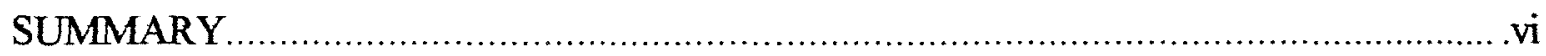

1 INTRODUÇÃO

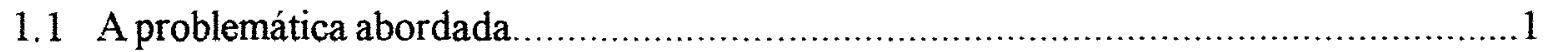

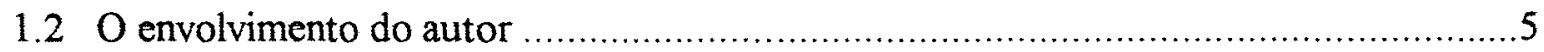

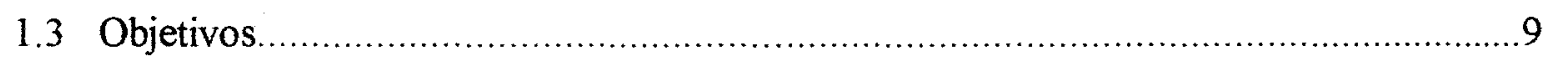

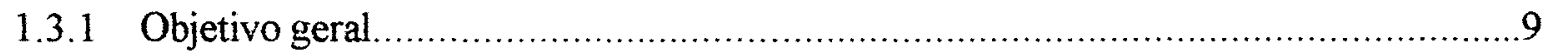

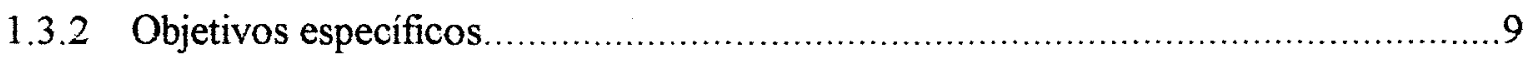

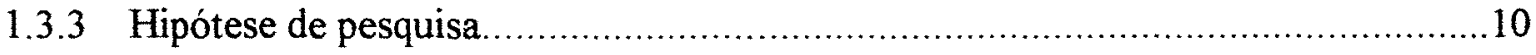

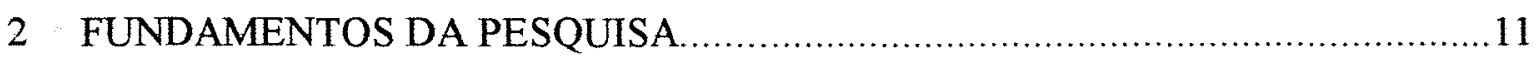

2.1 A ciência e a complexidade da questão ambiental ........................................... 11

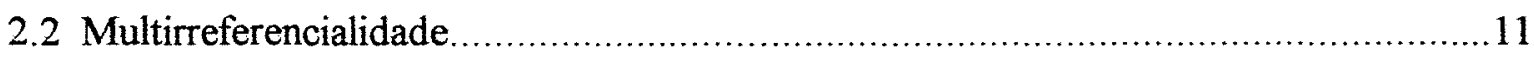

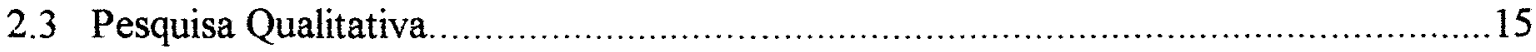

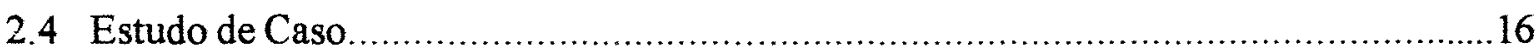

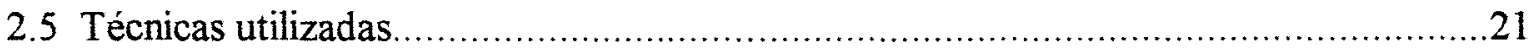

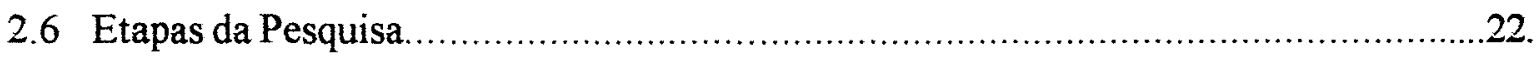

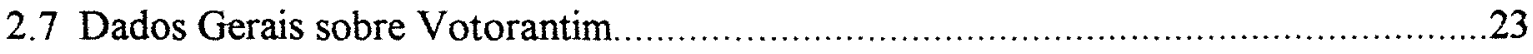

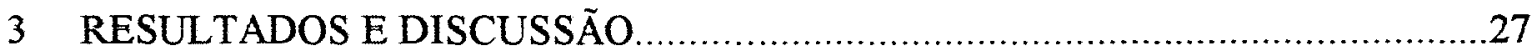

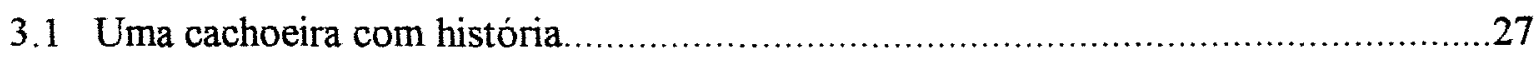

3.2 Resgate da história do Grupo Ecológico Cascata Branca........................................ 43

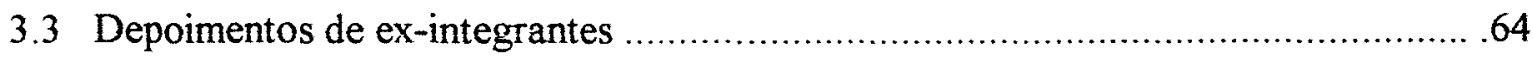

3.4 Outras iniciativas de intervenção na área da cachoeira.................................... 83

3.5 A fase Institucional (1993/2000) - Encontros e Desencontros............................. 85

3.6 Depoimentos de ex-prefeitos: a visão do poder público local .............................. 101

3.7 Ambientalismo, poder local e a questão Ambiental.......................................... 128 
3.8 O curso de extensão cultural "Áreas verdes urbanas, Educação Ambiental e

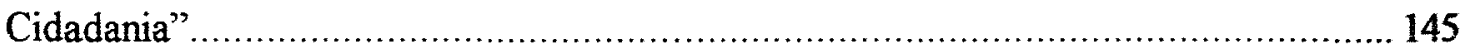

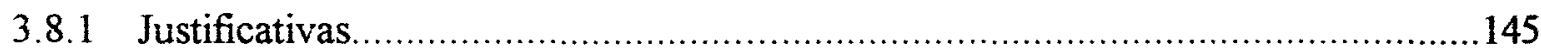

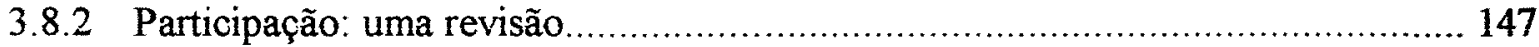

3.8.2.1 Participação: conceitos, maneiras, princípios........................................ 148

3.8.2.2 Participação e Construção do Conhecimento.............................................154

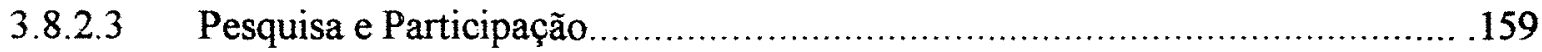

3.8.2.4 Pesquisas participantes: onde se aplicam? ........................................ 162

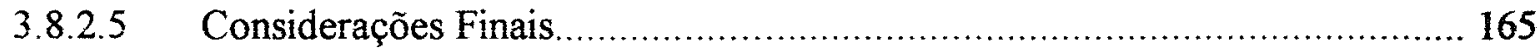

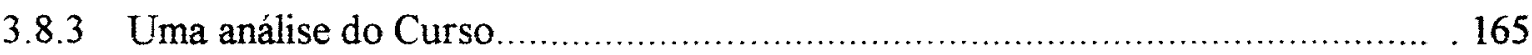

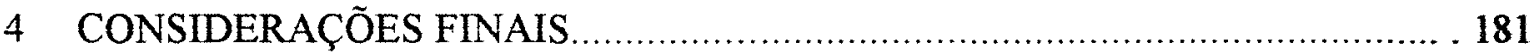

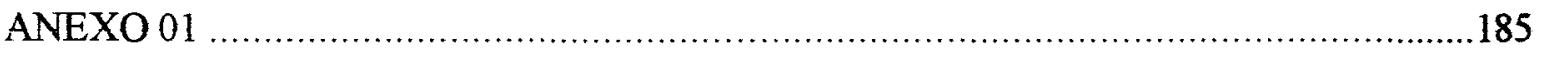

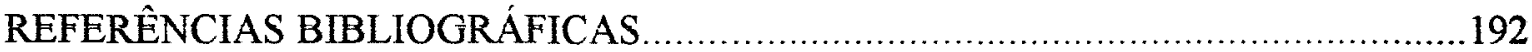




\title{
A LUTA PELA IMPLANTAÇÃO DE UMA ÁREA VERDE URBANA DENTRO DE UMA PROPOSTA DE EDUCAÇÃO AMBIENTAL: ESTUDO DE CASO NO MUNICÍPIO DE VOTORANTIM (SP)
}

\author{
Autor: ADRIANO LOPES PEREIRA DE MELO \\ Orientador: Prof. Dr. MARCOS SORRENTINO
}

\section{RESUMO}

O presente estudo aborda a questão da luta pela implantação de uma área verde urbana ocorrida no município de Votorantim, Estado de São Paulo, por parte de uma entidade ambientalista formada por estudantes de uma escola pública de primeiro grau e estudantes universitários.

Tendo como referencial teórico a multireferencialidade, por meio de pesquisa qualitativa (Estudo de Caso) e técnicas como entrevistas, pesquisa documental e intervenção através da realização de um curso de extensão universitária, foi feita uma análise e discussão dos avanços e problemas enfrentados na interação com o poder público local, do papel das pequenas entidades ambientalistas e da questão dos espaços livres de uso público urbanos.

As conclusões apontaram para a complexidade da inserção da questão ambiental local, da importância educativa das pequenas entidades ambientalistas enquanto espaço para o desenvolvimento da cidadania e da potencialidade do desenvolvimento de metodologias participativas de discussão de problemas ambientais urbanos e implantação de espaços livres de uso público urbanos. 


\title{
THE FIGHT FOR THE IMPLANTATION OF A URBAN GREEN SPACE INSIDE A ENVIRONMENTAL EDUCATION PROPOSAL: A CASE STUDY IN VOTORANTIM CITY, SAO PAUlo STATE
}

\author{
Author: ADRIANO LOPES PEREIRA DE MELO \\ Adviser: Prof. Dr. MARCOS SORRENTINO
}

\section{SUMMARY}

This study approaches the subject involved in the fight for the implantantion of na urban green space occured in Votorantim city, São Paulo State, promoted by a environmental entity formed by students of a public school of first degree and universitary students.

Tends as theoretical base the multirefenciality, by means of Qualitative Research (Study Case) and techniques as interviews, documental research and intervention though the accomplishment of a cultural extension course was made an analysis and discussion

about progress and problems faced in the interaction with local government, the role of the small environmental entities and the subject of urban green spaces.

The conclusions pointed for the complexity of the insertion of environmental question at local level government, the small environmental entities educational importance while space for the development of the citizenship and the potenciality of development of participatory methodologies for the discussion of urban environmental problems and implantantion on urban green open spaces. 


\section{INTRODUÇÃO}

\subsection{A problemática abordada}

Perto do ano 2.000, mais da metade dos habitantes do Planeta estarão vivendo em áreas urbanas. Essa urbanização é mais dramática e intensa em países ditos "em desenvolvimento", onde o número de habitantes na cidade teve um incremento de mais de 04 vezes desde 1950. Dois terços do incremento populacional nos países "em desenvolvimento" vêm sendo absorvido pelas cidades. Das 66 cidades que se esperam ter mais de 04 milhões de habitantes por volta do ano 2.000, 50 se localizam nesses paises (Kuchelmeister \& Braatz, 1993). Essa taxa de crescimento populacional sobrepujou a capacidade de planejamento de muitos governos municipais. Com isso, uma série de problemas de degradação sócio-ambiental surgiu nas áreas urbanas e peri-urbanas.

O município de Votorantim, localizado a $100 \mathrm{~km}$ da cidade de São Paulo, retrata com fidelidade todo esse processo de rápido crescimento urbano e degradação sócioambiental típico de nosso país. Com uma economia centrada na indústria, têm sua história intimamente ligada ao pioneirismo industrial brasileiro, sendo o berço do maior conglomerado industrial nacional, o Grupo Votorantim. Tornando-se autônomo em 1963 (era um distrito do vizinho município de Sorocaba), viveu com intensidade na década de 70 o "milagre brasileiro", tendo exercido (e ainda exercendo) uma forte atração em função dos empregos gerados pelas indústrias, e como consequência o crescimento populacional sofreu uma explosão provocada pela migração. O primeiro Plano Diretor, elaborado em 1967, constatou uma população de 20.000 habitantes, e baseado nas taxas de crescimento popucacional da época, estimou-se que em 1990 a população seria de 45.000 habitantes. As previsões ficaram muito aquém da realidade, uma vez que já segundo o censo do IBGE de 1980 , a população era de 50.454 habitantessaltando para 80.728 habitantes segundo o censo de 1991 (Prefeitura Municipal de Votorantim, 1986).

Tal crescimento populacional sem precedentes obviamente não foi acompanhado na mesma proporção de um planejamento e ação do poder público articulado no sentido de propiciar condições de vida adequadas à população, tendo surgido uma série de 
problemas, entre os quais destacamos a transformação de córregos e do rio Sorocaba em depositários de esgoto doméstico sem tratamento, grandes erosões dentro da área urbana, e talvez um dos problemas mais graves, que surgiu em função da atratividade da cidade como fonte de emprego (o que já não acontece): a ocupação de áreas públicas (áreas institucionais e áreas verdes) pela população de baixa renda como alternativa de moradia.

A proliferação de favelas é um fenômeno recente, $78.23 \%$ dos moradores tem até 05 anos de residência (Prefeitura Municipal de Votorantim, 1993). Existiam na época de estudo 29 núcleos de favelas com um total de 1187 barracos, abrigando uma população estimada de 4.900 pessoas. Tais áreas ocupadas com fins estranhos ao que originalmente se destinavam acabaram também por privar os demais moradores de espaços potenciais para o desenvolvimento de atividades de lazer, recreação e amenização ambiental, fundamentais para o bem-estar e qualidade de vida dentro do sítio urbano. $\mathrm{O}$ município conta com poucas áreas para tal, sendo que segundo dados do Plano Diretor de 1986, existiam apenas 08 praças na cidade, totalizando uma área de $54.914 .84 \mathrm{~m} 2$, resultando em $0,78 \mathrm{~m} 2$ de praça por habitante. Tal deficiência não se devia à inexistência de áreas verdes, pelo contrário, o mapa cadastral mostrava que era grande o número de áreas públicas não tratadas, espalhadas pela cidade. Seu conjunto totalizava $881.672,61 \mathrm{~m} 2 \mathrm{o}$ que dava uma quota de $12,60 \mathrm{~m} 2$ de área verde por habitante (Prefeitura Municipal de Votorantim, 1986). Devemos notar que de 1986 até os dias atuais o aumento populacional não foi proporcional ao aumento no oferecimento de espaços livres de uso público, pelo contrário, intensificou-se a problemática do favelamento como visto. Outro fator a considerar é como tem se dado o relacionamento da população com a cidade.

Em função da conjunção de uma série de fatores, têm se observado que o vandalismo contra o patrimônio público assume proporções assustadoras no município, envolvendo a destruição da vegetação plantada em praças e vias públicas, invasão e destruição de escolas públicas, sistema de sinalização e iluminação entre outros. A deposição de lixo e entulho em áreas inadequadas também é um grave problema, causando sérios transtornos à população, ao ambiente e ao poder público.

Assim como é no município que vivemos e sentimos os problemas ambientais/sociais/econômicos de forma direta dentro do cotidiano, é dentro do 
município que deve começar a busca concreta e a atuação para a solução desses problemas. Sendo a instância de poder mais próxima dos cidadãos, o poder público local tem importância fundamental nesse processo, assim como a população local através de suas organizações.

A nível planetário, observamos o crescimento da preocupação com a questão ambiental. Na Conferência da Organização das Nações Unidas sobre o Meio Ambiente Urbano, realizada em 1972, definiram-se os princípios do direito ao meio ambiente ecologicamente equilibrado para as atuais e futuras gerações. Vinte anos depois presenciamos em nosso país a CNUMAD-92, Conferência sobre o Meio Ambiente e Desenvolvimento, a maior Conferência organizada pela Organização das Nações Unidas, com a participação de quase todos os Chefes de Estado do mundo. Paralela à mesma, 1.300 organizações não-governamentais com atuação em 108 países de todo o mundo realizaram o "Fórum Internacional de ONGs e Movimentos Sociais", produzindo 36 planos de ação aprovados e reunidos sob a forma de Tratados, resultados do maior consenso jamais alcançado pela sociedade civil planetária.

Dentre esses tratados, destacamos o "Tratado sobre a Questão Urbana", com uma análise do processo de urbanização e seus problemas, onde colocou-se em seu preâmbulo:

"A ativa participação da sociedade civil, especialmente dos movimentos sociais, das entidades e associações populares, introduz novos atores como agentes decisivos na construção de um novo modelo de desenvolvimento e requer dos organismos internacionais e dos governos que estes o aceitem como interlocutores e se abram à participação democrática." (FORUM, 1992, p. 208).

Entre as propostas apresentadas pelo Fórum de ONGs frente a essa questão, destacamos:

"A articulação dos poderes públicos, dos agentes privados e atores sociais, criando mecanismos participativos para a formulação de políticas públicas, aproveitando tecnologias e processos 
alternativos que possibilitem o máximo aproveitamento dos recursos naturais e materiais, dentro da perspectiva social e de sustentabilidade" (FÓRUM,1992, p. 209-210).

Como produto da CNUMAD-92 (Conferência "oficial"), tivemos a Agenda 21, conjunto de compromissos assinados pelos governantes dos 179 países participantes e representantes das Organizações Não-Governamentais (ONGs), bem como membros da Comunidade Científica. Tal Documento contém 27 princípios gerais e declarações reunidos em 40 capítulos, divididos em 04 seções: Dimensão Social e Econômica, Gerenciamento e Conservação dos Recursos Naturais, Intensificação das Funções dos Grupos Majoritários e Significado das Implementações. O Capítulo 28 da Agenda 21 aborda a questão das Autoridades Regionais, constatando que muito dos problemas e soluções listados na Agenda 21 têm sua origem nas situações regionais e as autoridades locais têm importantes funções na melhoria da educação e na mobilização da sociedade para o Desenvolvimento Sustentável. As autoridades devem buscar informações e construir as estratégias consensuais junto às populações para buscar tal Modelo de Desenvolvimento (Sato \& Santos, 1996). A partir da divulgação da Agenda 21, teve início a discussão e implementação das "Agendas 21 Locais", através das quais Estados e Municípios, em parceria com entidades da sociedade civil, buscam tornar realidade as deliberações e decisões que compõem a Agenda.

A participação dos cidadãos nas questões que afetam o bem-estar e a qualidade de vida torna-se então uma necessidade reconhecida e defendida por todos. As Organizações Não-Governamentais surgiram e proliferaram como alternativa para a reflexão e ação concreta dos diversos setores sociais frente à realidade sócio-ambiental. Segundo levantamento realizado em dezembro de 1993, existiam na época por volta de 5.000 ONGs no país (Bernardes \& Nanne,1994), atuando em áreas como Defesa do Meio Ambiente, Movimentos Populares, Direitos da Mulher, Crianças Carentes, Prevenção e Tratamento da Aids entre outras questões.

No município de Votorantim, tivemos durante os anos de 90, 91, 92 e 93 a atuação de uma entidade ambientalista - o Grupo Ecológico Cascata Branca-tendo como bandeira principal a recuperação de uma patrimônio histórico, cultural e natural do 
município, Votu-raty, que em tupi-guarani significa Cascata Branca, notável paisagem natural situada em uma área de aproximadamente 10 hectares localizada próxima à região central do município. Essa cachoeira inspirou a denominação do então distrito e atual cidade assim como do maior conglomerado industrial nacional. Tal área também sintetiza com fidelidade as contradições e contrastes advindos de um crescimento urbano ambientalmente danoso e socialmente excludente: a despeito de sua importância histórico-cultural e das iniciativas de indivíduos e grupos para recuperar e revitalizar a área, a mesma permanece abandonada e com uma série de problemas não resolvidos: lançamento de esgoto doméstico sem tratamento, surgimento e proliferação de voçorocas e deslizamentos, ausência de cobertura florestal nativa em parte das encostas, deposição de entulho e lixo, ocupação irregular para fins de moradia, dentre outros.

Pretende-se, tendo como referencial teórico e metodológico a multireferencialidade e baseado em pesquisa qualitativa, estudar as relações entre diversos setores da sociedade local e a área onde se situa a cachoeira Votorantim, com ênfase às ações/omissões do Poder Público local e em especial analisar o papel desempenhado pelo Grupo Ecológico Cascata Branca durante seu período de maior atividade (90/91/92/93).

\section{$1.2 \mathbf{O}$ envolvimento do autor}

O presente trabalho resulta do envolvimento histórico do autor com a questão das áreas verdes urbanas e ambientalismo, iniciado durante a graduação em Engenharia Florestal na Escola Superior de Agricultura "Luiz de Queiroz" (1986/junho 1991).

O ponto de partida desse envolvimento foi o surgimento do Grupo de Educação Ambiental "Metamorfose", formado por acadêmicos de Engenharia Agronômica e Florestal no início de 1988, que tinha como um dos objetivos a utilização do potencial do Parque da ESALQ como instrumento para a sensibilização e educação ambiental, através da elaboração de programas de interpretação ambiental e atividades lúdico-educativas com estudantes de primeiro grau e visitantes do Parque. Foi uma primeira oportunidade de envolvimento com a temática da Educação Ambiental para a maior parte dos 
integrantes do Grupo, que de forma ainda pouco aprofundada procuravam conciliar a busca de maiores conhecimentos na temática com o desenvolvimento de atividades práticas. Os resultados desse trabalho foram apresentados no I Congresso Brasileiro de Educação Ambiental (1988), ocorrido em Ibirubá (R.S.), intitulado Programa "Seja o Verde" (Melo et al., 1988) e também no IV Simpósio Estadual de Educação Ambiental (1988), ocorrido em Santos, em novembro de 1988.

Após a desestruturação desse primeiro Grupo, alguns de seus participantes passaram a desenvolver projetos de pesquisa individuais ligados à questão da Educação Ambiental, enquanto outros passaram a se envolver com outras áreas dentro das Ciências Florestais. O autor passou então a se envolver com a temática das Áreas Verdes Urbanas, elaborando e desenvolvendo o Projeto de Pesquisa "Levantamento das Áreas Verdes de Piracicaba e Proposta de Implantação com Participação Comunitária", com orientação do Prof. Marcos Sorrentino, de 1988 até 1990. Esse Projeto de Pesquisa tinha como objetivos principais a realização de um diagnóstico da situação dos Espaços Livres de Uso Público tratados (praças implantadas) e não tratados (Sistemas de Lazer de loteamentos), tanto em relação a situação física existente ,através de fichas descritivas, como também das percepções da população do entorno em relação a esses espaços. Propôs-se a definir uma área verde especifica para desencadear um processo de implantação com Participação Comunitária (Melo \& Meira, 1989).

Uma estratégia utilizada para a difusão da questão das áreas verdes e seu potencial de uso educativo junto aos professores da rede pública foi a realização do Curso de Difusão Cultural "As Áreas Verdes na Educação Ambiental", promovido pela CENP (Coordenadoria de Estudos e Norma Pedagógicas da Secretaria de Estado da Educação), CECAE (Comissão Especial de Coordenação de Atividades de Extensão Universitária da USP), Secretaria de Serviços Públicos de Piracicaba e Departamento de Ciências Florestais da ESALQ/USP. Com carga horária de 40 horas, foi feito um embasamento teórico sobre a questão dos Espaços Livres de Uso Público e temas correlatos (Paisagismo, Áreas Verdes Urbanas, Recuperação de Áreas Degradadas, Arborização Urbana) e atividades práticas, no caso um levantamento geral sobre várias situações de áreas destinadas a sistema de lazer bem como a intervenção em uma área 
verde específica (entrevistas com moradores do entorno, propostas de ocupação da área).

Esse trabalho foi apresentado na I Reunião Paulista de Iniciação Científica em Ciências Agrárias e IV Congresso de Iniciação Científica da ESALQ, ocorrida em 1989 (Melo et al., 1989).

No início de 1989, o autor foi selecionado para compor, juntamente com mais três alunos, a primeira turma do PET - Programa Especial de Treinamento da CAPES (Coordenadoria de Aperfeiçoamento de Pessoal de Nível Superior) na área de Ecologia de Sistemas Agroflorestais, inicialmente com a orientação do Prof. Dr. Walter de Paula Lima (1989) e depois com o Prof. Dr. Virgílio Maurício Viana (1990/junho 1991). Além da continuidade do desenvolvimento dos projetos de Pesquisa individuais, os membros do PET desenvolviam atividades de interação com a comunidade esalqueana (Organização do Forum de Debates, Elaboração do Jornal "Novos Ecos") e também atividades de interação com o município de Piracicaba (concepção e desenvolvimento inicial do Projeto "Subsídios para a Elaboração do Plano Diretor do Engenho Central"), em conjunto com a Prefeitura Municipal. A oportunidade de participar do programa contribuiu para o aprimoramento da formação crítica e científica, tendo em vista a proposta ampla do Programa.

Destaca-se também nesse periodo o desenvolvimento de uma atividade dentro da Disciplina optativa "Educação Ambiental", ministrada pelo Prof. Marcos Sorrentino, onde o autor dentro de um grupo de intervenção desenvolveu a pesquisa "Extensão Universitária - Experiência com Educação Ambiental em Escola Pública de 1o. Grau", apresentado no VI Congresso Florestal Brasileiro, ocorrido em Campos do Jordão (S.P.) em 1990 (Sorrentino et al., 1990).

Em 1990, o autor iniciou, juntamente com uma colega acadêmica de Engenharia Florestal da Escola Superior de Agricultura de Lavras (MG) e também moradora de Votorantim, uma movimentação para a viabilização da implantação de um Parque Urbano Municipal na área do maior patrimônio histórico, paisagísitico e ambiental de sua cidade natal, Votorantim (S.P.) : a área da Cachoeira situada no bairro da Chave, junto a região central, Cachoeira esta que inclusive inspirou a denominação da cidade e de um dos maiores grupos industriais do pais, o Grupo Votorantim, cujo surgimento confunde- 
se com o próprio surgimento daquela então vila industrial, no início do século. 0 envolvimento nessa questão seria então uma continuidade do envolvimento com a temática das Áreas Verdes Urbanas associado com a disposição de contribuir, dentro da área de formação técnica, para a melhoria das condições ambientais de um patrimônio de sua cidade.

Essa movimentação, iniciado com uma vistoria na área com a cobertura da imprensa local em agosto de 1990, desencadeou uma série de ações que levaram a formação da entidade ambientalista "Grupo Ecológico Cascata Branca", que atuou intensamente durante os anos 90,91 e 92. A riqueza do material gerado e das ações que foram efetuadas e a necessidade de uma reflexão mais aprofundada sobre as questões relativas à temática das Áreas Verdes Urbanas, Ambientalismo e Poder Público Municipal motivaram a elaboração da presente Dissertação. Portanto, o tema passa por uma ligação histórica e profunda do autor com a temática, ligação esta que de certa forma teve continuidade mesmo após a o término da graduação e vai até a atualidade.

Em 1992, o autor foi contratado para trabalhar no Departamento Estadual de Proteção de Recursos Naturais (DEPRN), Equipe Técnica de Registro (Vale do Ribeira), dificultando a continuidade da atuação no município, sendo que na época o Grupo já se encontrava em processo de desestruturação. De janeiro a setembro de 1993 o autor trabalhou com Pesquisador Científico I do Instituto de Botânica da Secretaria de Estado de Meio Ambiente (Área de Educação Ambiental), desenvolvendo suas atividades no Jardim Botânico (capital), onde tentou uma aproximação junto à Prefeitura Municipal no sentido de desenvolver algum trabalho conjunto da Instituição com a Prefeitura na área da Cachoeira. Em setembro de 1993, o autor, recebendo convite da administração municipal assumiu um cargo na Prefeitura, desvinculando-se no Instituto de Botânica, onde então buscou estruturar um Setor de Meio Ambiente e retomar a discussão sobre a questão do Parque da Cachoeira, porém sem sucesso devida a uma série de fatores que serão apresentados e discutidos. Atualmente, continua desenvolvendo suas atividades dentro da Prefeitura, vinculado a Secretaria de Serviços Públicos/Setor de Parques e Jardins. 
Essa fase em que o autor passa a fazer parte do corpo técnico da administração municipal será objeto de uma análise, também enfoncando a questão do Parque Municipal da Cachoeira, o que propiciará subsídios para uma discussão bastante rica sobre o Poder Público e a questão ambiental, dentro das limitações colocadas por um Estudo de Caso. O fato do município de Votorantim, um dos berços da industrialização brasileira, ter uma importância como exemplo do processo de industrialização (seguido de crescimento urbano desordenado e degradação ambiental)e aumenta a riqueza dessa discussão, podendo colaborar para um melhor entendimento das complexas e multifacetadas relações entre Poder Público, a questão ambiental expressa na temática das áreas verdes urbanas e o movimento ambientalista.

\subsection{Objetivos}

\subsubsection{Objetivo geral}

Contribuir para a análise e aprimoramento de processos paarticipativos de educação ambiental e de melhorias do ambiente e da qualidade de vida, através de um estudo de caso voltado à conquista e implantação de uma área verde municipal.

\subsubsection{Objetivos específicos}

Refletir e analisar o papel desempenhado pela entidade ambientalista "Grupo Ecológico Cascata Branca" durante seu período de maior atividade, sob a ótica de seus participantes e de administradores locais (ex-prefeitos) e assim fornecer subsídios para uma melhor compreensão sobre a participação dos cidadãos em questões públicas e sobre o funcionamento e importância das pequenas entidades ambientalistas;

Realizar um levantamento dos materiais históricos - relatos, expressões artísticas, fotografias - e de iniciativas de projetos e propostas de uso público para a área da 
cachoeira, elaboradas pelo Poder Público, entidades e iniciativas individuais, de forma a fornecer subsídios para a discussão e definição de uma proposta de projeto participativo;

Discutir a questão da implantação de políticas públicas locais de meio ambiente a partir da experiência ocorrida no município de Votorantim, S.P.

\subsubsection{Hipótese de pesquisa}

$\mathrm{O}$ conceito de hipótese aqui empregado tem mais a função de nortear a concepção e o desenvolvimento da pesquisa, uma vez que os fenômenos sociais são complexos e multifacetados. A pesquisa não se desenvolveu no sentido de corroborar ou negar uma hipótese pré-formulada

A idéia geral que orienta a concepção e desenvolvimento do presente projeto pode ser sintetizada na percepção de que o envolvimento efetivo da população nos projetos do Poder Público, em especial os relativos à implantação de espaços livres de uso público é elemento fundamental para o sucesso desses projetos, de forma a atender os anseios e aspirações da população e obter apoio para o correto uso, conservação e manutenção desses espaços. A "falta de sintonia" do poder público com as demandas populares por melhorias ambientais e de qualidade de vida (expressa nesse caso pela reivindicação pela implantação de uma área verde e por uma política municipal de meio ambiente) provoca prejuizos de "legitimidade" dos poderes constituidos e de distancimento do indivíduo em relação a coisa pública. Essa situação contraria as

tendências de incorporação da questão ambiental na sociedade em geral, empresas e governos que vem ocorrido nos últimos anos. 


\section{FUNDAMENTOS DA PESQUISA}

\subsection{Eixos de análise}

A presente Dissertação tem com referencias teóricos de análise dois eixos principais.

O primeiro se insere na área das Ciências Sociais, relativo aos trabalhos realizados no campo dos novos movimentos sociais e especificamente o movimento ambietalista, com ênfase na incorporação da temática ambiental (incluindo a urbana), com trabalhos de autores como Eduardo Viola (1992, 1995), principalmente na abordagem do ambientalismo multisetorial deste último, bem como nos trabalhos relativos ao histórico e análise do ambientalismo mundial e nacional, como John McCormick (1992) "Rumo ao Paraíso: a história do movimento ambientalista", Marcos Sorrentino (1988, 1995), Samyra Crespo \&Pedro Leitão (1993), dentre outros.

O segundo eixo de análise refere-se a área de Políticas Públicas de Meio Ambiente, com referências principalmente nos trabalhos de Leila da Costa Ferreira (1998), Menezes (1997), Vieira \& Bredariol (1998) e outros trabalhos na área de política ambiental urbana, inclusive municipal.

\subsection{Multirreferencialidade}

O conceito de multireferencialidade vem sendo trabalhado há aproximadamente trinta anos por pesquisadores da área de educação como Jacques Ardoino (Ardoino, 1988). Essa perspectiva procurou desde o início da sua concepção se diferenciar da idéia de multidimensionalidade, pois segundo Ardoino essa noção seria pensada em termos de diferenças não suficientes para excluir a esperança de um retorno ulterior a uma homogeneidade, enquanto que a multireferencialidade postularia uma heterogeneidade inerente (não redutíveis) de perspectivas colocadas em contribuição. Segundo Ardoino,

“...a multireferencialidade tenta contribuir com uma resposta

à complexidade fornecida por certos objetos dos quais não se 
poderia, de outra forma, permitir a inteligibilidade, ainda que a multidensionalidade permaneça uma leitura do complicado (definido pelo número e intensidade de suas variáveis), objeto sempre suposto decomponivel, redutível ao estado de elementos mais simples, mais puros, segundo o processo científico canônico" (Ardoino, 1998, p.201).

Ardoino (1988) coloca que a multireferencialidade propõe uma leitura plural de seus objetos, a partir da assunção da hipótese da complexidade e até mesmo da hipercomplexidade. Outras colocações auxiliam a compreensão do conceito e abrangência da multirrenfencilidade:

"Multirreferencialidade, na sua origem, é um assunto de pesquisadores e de práticos também. É uma resposta à constatação da complexidade das práticas sociais e, num segundo tempo, o esforço para dar conta, de um modo um pouco mais rigoroso, desta mesma complexidade, diversidade e pluralidade.

Multirreferencialidade é uma pluralidade de olhares dirigido à uma realidade e, em segundo lugar, uma pluralidade de linguagens para traduzir essa mesma realidade e os olhares dirigidos a ela. $\mathrm{O}$ que sublinha a necessidade da linguagem correspondente para dar conta da especificidades desses olhares"(Ardoino, 1998, p.205).

Essas colocações indicam a multirreferencialidade como instrumental tanto para a pesquisa científica quanto para as práticas sociais.

Abordando a forma atual da ciência, atomizada e sem visão do todo e na busca do desenvolvimento do paradigma de complexidade, Morin (87) colocou que

"É precisamente esta renúncia que a universidade nos ensina. A escola da informação é uma escola de luto. Todo neófito que entra na investigação vê que lhe impõem a maior renúncia do conhecimento (...) Demonstram-lhe que o crescimento informacional e a heterogeneização do saber ultrapassam toda a possibilidade de engramação e do tratamento do cérebro humano. 
Garantem-lhe que não deve lamentar mas felicitar-se com este facto. Deveria pois consagrar a sua inteligência inteira a aumentar este saber. Integram-no numa equipa especializada, e nesta expressão o termo forte é "especializada"e não "equipa" (Morin, 1987, p.16).

A abordagem de Morin tem como um dos princípios a crise da sociedade e a necessidade de investigar ao nível radical da teoria, baseada numa rearticulação entre as ciências da natureza e da antropossociologia, e que essa rearticulação requer uma reorganização da estrutura do saber.

Morin (1987) na introdução do paradigma da complexidade com uma crítica a estrutura da ciência, cita ainda a indissociabilidade do pesquisador e seus valores com seu objeto de estudo:

"Porquê falar de mim? Não é decente, normal e sério que, quando se tratando de ciência, de conhecimento e de pensamento, o autor se apague atrás da sua obra e se desvaneça num discurso tornado impessoal? Devemos, pelo contrário, saber que é ai que a comédia triunfa. O sujeito desaparece do seu discurso instala-se, de facto, na torre de controlo. Fingindo deixar lugar ao sol copernicano, reconstitui um sistema de Ptolomeu cujo centro é o seu espirito" (Morin, 1987, p.26).

Esta questão do isolamento e neutralidade do pesquisador com seu objeto de estudo se encontra representada neste trabalho pelo fato do autor, longe de estar analisando um problema de pesquisa com seus limites definidos e metodologia préestabelecida fora de sua realidade de trabalho cotidiano, foi e continua sendo protagonista desses eventos analisados.

Outro conceito inserido na multireferencialidade é a bricolagem, que segundo Lapassade (1998), citando Karl Popper, seria a regra fudamental e incontornável das ciências sociais, que estariam de certa forma condenadas a trabalhar dessa forma porque seu objeto de estudo é infinitamente complexo. 
Barbosa (1998), abordando esse conceito colocado por Ardoino cita do preconceito que a princípio esse termo traria em sua própria etimologia, como "conserto realizado de qualquer maneira" e "trabalho de amador pouco apurado". Cita que sendo outrora teriam havido sentidos mais técnicos, para além de "trabalhos manuais pouco remunerados", como para designar jogos que exigiam habilidade. Barbosa (1998) ainda cita que segundo Ardoino (1998) há uma tendência de reabilitalo "ao nivel da ciência e da técnica"(Barbosa, 1998, p.203).

Segundo Barbosa (1998), citando a afirmação de Ardoino de que a bricolagem sempre teve associada a idéia de improvisação hábil e de astúcia, colocou que um conceito de bricolage seria a de "ir aqui e lá, eventualmente procurar obter, pelo desvio, indiretamente, aquilo que não se pode alcançar de forma direta" (Barbosa, 1988, p,203). Barbosa (1998) conclui sua colocação sobre o conceito de bricolagem que uma opção seria aportuguesar a forma francesa, adotando a palavra bricolagem , de forma a minimizar o caráter pejorativo das possiveis traduções do francês.

Tendo como pano de fundo sua pesquisa sobre a cultura hip hop francesa, Lapassade (1998) cita as diferentes referências que buscou ao longo do desenvolvimento do seu trabalho, como a etnografia, a análise institucional e Universidade como dispositivo institucional de pesquisa-ação para a intervenção social e a psicologia social experimental. Essa busca de referências foi feita conforme o desenvolvimento da pesquisa, tendo a bricolagem como elemento essencial:

“(...) é preciso considerar que a bricolagem, longe de constituir a "parte feia" da ciência social, deve ser considerada, pelo contrário, como uma parte social e incontornável do seu procedimento. A abordagem multirreferencial não escapa dela, mesmo se ela não se reduza a isto. Parece-me, em todo caso, que deveríamos consideralá pelo menos como um primeiro nível de uma abordagem de perspectivas múltiplas; para aprender a praticá-la, o aprendizpesquisador deve também aprender a "bricolar"'(Lapassade, 1998, p.136). 
Essa introdução buscou dar corpo a multirreferencialidade de teorias, interpretações e procedimentos metodológicos feitas pelo autor ao longo de seu trabalho de pesquisa, com a identificação dos dois conjuntos de referências de áreas distintas do conhecimento que auxiliaram no entendimento e análise dos problemas estudados, detalhados no item 2.1 .

\subsection{Pesquisa Qualitativa}

Este trabalho insere-se dentro da área da Ciência Social como uma Pesquisa Qualitativa.

"Por Pesquisa Qualitativa entende-se qualquer tipo de pesquisa que gera constatações não obtidas por meio de procedimentos estatísticos ou outros meios quantitativos. Ela se refere às pesquisas sobre vidas das pessoas, histórias, comportamentos como também funcionamento de organizações, movimentos sociais ou relações internacionais. Alguns dados podem ser quantitativos, mas são analisados qualitativamente" (Strauss \& Corbin, citados por Alencar,1996, p.2).

Os pesquisadores qualitativos enfatizam a natureza social da construção da realidade, a intima relação entre o pesquisador e o que é estudado e as limitações situacionais que moldam a investigação. Tais pesquisadores realçam a natureza repleta de valores que envolvem a investigação. Eles buscam respostas para questões que colocam em relevo como a experiência social surge e adquire significado. Em contraste, os estudos quantitativos enfatizam a mensuração e a análise das relações causais entre variáveis, não processos. É dado a entender que a investigação se dá dentro de uma estrutura livre de valores (Denzin \& Lincoln, citados por Alencar, 1996).

Os métodos qualitativos são interativos. Existem, durante o processo de pesquisa, oportunidades para se revisar entrevistas, roteiros, anotações de observações à luz de novos fatos que vão emergindo. Até mesmo o projeto de pesquisa pode ser alvo de 
modificações durante o estágio de coleta de dados. Tal interação não é comum na coleta de dados de uma pesquisa quantitativa (Alencar ,1996).

\subsection{Estudo de Caso}

O presente trabalho é um Estudo de Caso. Segundo Stake, citado por Alencar (1996), o Estudo de Caso não é, em si, uma escolha metodológica, mas a escolha de um objeto a ser estudado.

Segundo Worsley, citado por Alencar (1996), existem dois procedimentos diferentes por meio dos quais os princípios teóricos, desenvolvidos nas ciências sociais, podem retornar à realidade que thes deu origem:

a) pelo uso de modelos - estabelecimento de conexões (hipóteses), admitidamente simplificadas, entre fenômenos em termos de princípios teóricos abstratos empregados pelos cientistas sociais;

b) pelo estudo de caso - exame de um conjunto de ações em desenvolvimento e mostrar como os princípios teóricos se manifestam nessas ações.

Os mesmos autores colocam que o estudo de caso é o estudo de um caso, seja ele simples e específico ou complexo e abstrato. $\mathrm{O}$ caso é sempre bem delimitado, devendo ter seus contornos claramente definidos no desenrolar do estudo. $\mathrm{O}$ caso pode ser similar a outros, mas é ao mesmo tempo distinto, pois tem interesse próprio, singular. Segundo Goode \& Hatt citados por Alencar (1986), o caso se destaca por se constituir uma unidade dentro de um sistema mais amplo. $\mathrm{O}$ interesse, portanto, incide naquilo que ele tem de único, de particular, mesmo que posteriormente venham a ficar evidentes certas semelhanças com outros casos ou situações. Quando queremos estudar algo singular, que tenha um valor em si mesmo, devemos escolher o estudo de caso (Lüdke \& André, 1986).

Alencar (1996) coloca, porém, que nem todos os pesquisadores reconhecem o estudo de caso como uma forma "legítima" de investigação social, argumentando esse posicionamento metodológico com base nos seguintes fatores:

a) pequena abrangência do estudo de caso em contraste com "survey" de ampla amostra. 
b) a natureza "menos formalizada" das técnicas de coleta de informações usualmente empregada no estudo de caso, em contraste com técnicas mais estruturadas de "survey".

Segundo esse mesmo autor, a critica mais comum, fundamentada no primeiro argumento é de que o estudo de caso não permite generalizações, devido a sua pouca representatividade e conseqüente incapacidade de se encontrar todas as dimensões de um fenômeno em um único contexto, e em relação ao segundo argumento a principal crítica é de que o estudo de caso não permite um controle rigoroso das informações coletadas, relacionada ao conceito de confiabilidade. Tais argumentos resultam de idéias positivistas a respeito das ciências sociais. Filstead, citado por Alencar (1996), coloca que foi a determinação de tornar as ciências sociais "tão científicas" quanto às ciências naturais levou a este estado de inquietação com a abordagem qualitativa e motivou uma preocupação exagerada com a confiabilidade mas não com necessariamente com a validade.

Filstead, citado por Alencar (1996), observou que embora os problemas relacionados com a validade têm recebido pouca atenção na abordagem positivista, este não é o caso na abordagem qualitativa.

Murray et. al., citados por Alencar (1986), consideram que os estudo de caso têm um papel importante nas ciências sociais como iniciador de teorias, além de que a análise de diferentes casos pode proporcionar generalizações. Murray (1971), citado por Alencar (1996), expôs as razões metodológicas pelas quais os estudos de caso são uma forma legítima de pesquisa assentam-se nas seguintes considerações:

"1. Os estudos de caso podem ilustrar generalizações que foram estabelecidas e aceitas. Ainda que eles sejam pouco abrangentes, as generalizações podem ganhar novos significados sendo ilustradas em diferentes contextos;

2. O estudo de caso pode se constituir em um teste de uma teoria que, embora aceita como uma "verdade universal" necessita ser comprovada em todas as instâncias. Ao estudar uma situação específica por meio de uma hipótese derivada de uma teoria, os 
resultados obtidos podem invalidá-las, ainda que em uma instância particular;

3. Relações entre circunstâncias particulares, observadas a partir de um único estudo de caso, podem sugerir conexões que necessitam ser exploradas em outras instâncias. Assim, os resultados de um único estudo de caso pode estimular a formulação de hipóteses que orientarão novas pesquisas, cujos resultados poderão conduzir a generalizações" (Murray, citado por Alencar, 1996, p.93).

Além dessas considerações, Murray, citado por Alencar (1996), também considera que os estudos de caso adicionam dimensões totalmente diferentes aos fundamentos do conhecimento:

"'Ao mostrarem que as "coisas" podem ter grandes variações em diferentes circunstâncias, bem como complexidades múltiplas, os estudos de casos ilustram o quanto as variáveis manipuladas em modelos e teorias abstratas são, na prática, envolvidas pela ação humana. Dessa forma, ainda que não fosse possível o estabelecimento de generalizações a partir dos estudos de casos, eles podem estimular a busca de situações mais tangiveis do que as oferecidas pelos modelos e teorias, mostrando como as situações são compreendidas, avaliadas e manipuladas pelos seres humanos"'”'(Murray, citado por Alencar,1996, p.94)

Lüdke \& André (1986) colocam entre as características fundamentais do estudo de caso as seguintes:

"1. Os estudos de caso visam à descoberta Mesmo que o investigador parta de alguns pressupotos teóricos iniciais, ele procurará se manter constantemente atento a novos elementos que podem emergir como importante durante o estudo. O quadro teórico inicial servirá como um esqueleto, de estrutura básica a partir do qual novos aspectos poderão ser detectados, novos elementos ou dimensões poderão ser arrescentados, na medida que 
o estudo avance (...) Essa característica se fundamenta no pressuposto de que o conhecimento não é algo acabado, mas uma construção que se faz e refaz constantemente. Assim sendo, o pesquisador estará sempre buscando novas respostas e novas indagações no desenvolvimento do seu trabalho.

2. Os estudos de caso enfatizam a "interpretação em contexto". Um princípio básico desse tipo de estudo é que, para uma apreensão mais completa do objeto, é preciso levar em conta o contexto em que ele se situa"( Lüdke \& André, 1986, p.18).

No caso em tela, surge a importância de realizar todo um histórico do município e suas características como parte do contexto no qual a pesquisa se insere.

“3. Os estudos de caso buscam retratar a realidade de forma complexa e profunda. $\mathrm{O}$ pesquisador procura revelar a multiplicidade de dimensões presentes numa determinada situação ou problema, focalizando-o como um todo.

4. Os estudos de caso usam uma variedade de fontes de informação. Ao desenvolver o estudo de caso, o pesquisador recorre a uma variedade de dados, coletados em diferentes momentos, em situações variadas e com uma variedade de tipos de informantes"( Lüdke \& André, 1986, p.19).

No caso específico, entre as técnicas utilizadas estão a entrevista, a análise documental e a intervenção prática através da realização de um Curso de Extensão Universitária.

"5. Os estudos de caso revelam experiência vicária e permitem generalizações naturalísticas. $O$ pesquisador procura relatar as suas experiências durante o estudo de modo ao leitor ou usuário possa fazer as suas "generalizações naturalísticas". Em lugar da pergunda: esse caso é representativo do quê?, o leitor vai indagar: o que eu posso (ou não) aplicar deste caso em minha situação?"(Lüdke \& André, 1986, p.19). 
Segundo Stake, citado por Lüdke \& André, (1986, p.19).essa generalização naturalística ocorre em função do conhecimento experencial do sujeito, no momento em que este tenta associar dados encontrados no estudo com dados que são frutos das suas experiências pessoais.

“6. Estudos de caso procuram representar os diferentes e às vezes conflitantes pontos de vista presentes numa situação social" (Lüdke \& André, 1986, p.20).

Isso ocorre quando o objeto ou situação estudados podem suscitar opiniões divergentes, então o pesquisador vai procurar trazer para seu estudo essa divergência de opiniões, revelando ainda o seu próprio ponto de vista sobre a questão, sendo deixado ao usuário do estudo que tirem suas conclusões sobre esses aspectos contraditórios. No caso estudado, o autor está inteiramente envolvido com o objeto de estudo, sendo um dos protagonistas, estando o conflito presente em várias etapas do processo em função dos princípios de trabalho e atuação postos em prática. Ainda segundo Lüdke \& André (1986),

" o pressuposto que fundamenta essa orientação é o de que a realidade pode ser vista sob diferentes perspectivas, não havendo uma única que seja a verdadeira. Assim, são dados vários elementos para que o leitor possa chegar às suas próprias conclusões e decisões, além de, evidentemente, das conclusões do próprio investigador"(Lüdke \& André, 1986, p.20).

“7. Os relatos do estudo de caso utilizam uma linguagem e uma forma mais acessivel do que os outros relatórios de pesquisa" (Lüdke \& André, 1986, p.20).

Geralmente os relatórios e dados dos estudos de caso podem ser apresentados numa variedade de formas (desenhos, fotografias, slides, discussões, mesasredondas), apresentado geralmente um estilo de escrita informal, narrativo. É possível também que um mesmo caso tenha diferentes formas de relato, em função do tipo de usuário a que se destina, devendo existir uma preocupação com uma transmissão clara, direta e bem articulada do caso e um estilo que se aproxime da experiência pessoal do leitor. 


\subsection{Técnicas utilizadas}

Pesquisa documental

Consistiu no resgate de materiais bibliográficos e artísticos sobre a área de estudo, a Cachoeira Votorantim. Envolveu a pesquisa em relatos de naturalistas do século XIX, historiadores locais e artigos na imprensa em geral.

Em relação ao histórico do Grupo Ecológico, procedeu-se a pesquisa sobre os materiais gerados (relatos de reuniões, atas, materiais produzidos, série de artigos na imprensa local e regional), que se encontravam dispersos tanto na Escola que sediou o Grupo quanto como em poder de alguns de seus ex-integrantes.

Foi utilizado também o arquivo pessoal do autor, com muitos materiais e anotações feitos ao longo dos anos de envolvimento com a entidade ambientalista como participante.

Entrevistas

Foram realizadas uma série de entrevistas com ex-integrantes do Grupo Ecológico Cascata Branca, colaboradores diretos e indiretos e outras pessoas relacionadas em iniciativas individuais de intervenção/propostas de uso para a área, com destaque para os ex-prefeitos José de Oliveira Souza ("Zeca Padeiro"), que administrou a cidade de Votorantim na época de atuação mais intensa do Grupo Ecológico e o exprefeito Erinaldo Alves da Silva, que foi prefeito por três vezes (31/01/73 a 31/01/77, 01/02/83 a 31/12/88 e 01/01/93 a 31/12/96) e foi o responsável pela vinda do autor ao corpo de funcionários da Prefeitura.

Optou-se por não realizar as entrevistas à partir de roteiros pré-estabelecidos, em função de não limitar os depoimentos e permitir explorar ao máximo o relato da vivência dos entrevistados. Seguiram-se as orientações básicas de publicações como Lodi (1971), Garret (1967) e Alencar (1986). 
Intervenção: Realização e Avaliação do Curso de Difusão Cultural "Áreas Verdes Urbanas, Educação Ambiental e Cidadania"

O curso foi realizado em setembro/outubro de 1997, sendo destinado ao público em geral e entidades da sociedade civil local do município de Votorantim interessados na questão das áreas verdes urbanas, como associações de moradores, grupo escoteiro, clubes de serviço e outros. O programa incluiu uma parte teórico/expositiva, com subsídios sobre a questão ambiental e áreas verdes urbanas e atividades práticas, entre as quais o diagnóstico da situação geral das áreas verdes do município e de uma área específica: a cachoeira Votorantim.

\subsection{Etapas da Pesquisa}

A Pesquisa teve três partes distintas e bem definidas, a saber:

Resgate do papel desempenhado pela entidade ambientalista "Grupo Ecológico Cascata Branca" e histórico sobre a área da Cachoeira e sua importância

Por meio de análise documental e entrevistas, procurou-se resgatar todo o processo de surgimento e atuação intensa do Grupo Ecológico Cascata Branca, com ênfase na movimentação em prol da implantação do Parque Municipal da Cachoeira, bem como de outras iniciativas de individuos e grupos organizados bem como da administração pública municipal em relação àquela área. Manifestações individuais registradas na imprensa igadas direta ou indiretamente ao tema também foram incorporadas nessa fase.

Realização do Curso de Difusão Cultural "Áreas Verdes Urbanas, Educação Ambiental e Cidadania"

O curso teve como um dos objetivos a tentativa de envolvimento de diferentes setores da sociedade civil local e indíviduos interessados na questão das áreas verdes urbanas, de forma a fornecer subsidios e estimular a iniciativa para a intervenção nessas áreas. Foi realizado um "diagnóstico participativo" da situação da área destinada ao Parque da Cachoeira, com o uso de princípios de DRP - Diagnóstico Rápido 
Participativo. Tal curso propiciou uma série de reflexões em relação à temática das áreas verdes urbanas e participação.

\section{Análise das Ações e Omissões do Poder Público em relação à implantação do Parque Municipal da Cachoeira e a questão ambiental local}

Por meio de análise documental, serão apresentadas as iniciativas e atitudes do Poder Público local em relação à proposta de implantação do Parque Municipal da cachoeira, com o objetivo de expandir a discussão para a própria incorporação da questão ambiental como um todo na administração municipal, principalmente após o ingresso do autor no quadro de servidores municipais (setembro/1993). Propiciará uma reflexão sobre o papel das entidades ambientalistas e do poder público em relação a complexidade das questões ambientais. A realização de duas entrevistas com ex-prefeitos forneceu rico material analítico nessa etapa.

\subsection{Dados Gerais sobre Votorantim}

\section{Dados Gerais}

\section{Localização}

O município de Votorantim localiza-se na zona fisiográfica de Sorocaba, em região de relevo montanhoso, dotado de aclives e declives acentuados e vales profundos. Suas coordenadas geográficas, segundo o I.G.C. são 23o. 33' de latitude e 17 o e $27^{\prime}$ de longitude. A sede municipal fica a cerca de $80 \mathrm{~km}$. da capital do Estado (Prefeitura Municipal de Votorantim, 1986).

Limites

O município confronta ao Norte com o de Sorocaba, ao Sul com os de Ibiúna e Piedade, a Leste com os de Sorocaba, Aluminio e Mairinque e a oeste com os de Sorocaba e Salto de Pirapora. A sede do município localiza-se nas proximidades da 
Rodovia Raposo Tavares, ao Sul da cidade de Sorocaba, estendendo-se pelo Vale do Rio Sorocaba e suas encostas adjacentes (Prefeitura Municipal de Votorantim, 1986).

Superficie

A superficie do Município, segundo dados do I.G.C., é de $177 \mathrm{~km} 2$ (Prefeitura Municipal de Votorantim, 1986).

Clima

O clima de Votorantim, conforme José Setzer em "Contribuição para o estudo do clima no Estado de São Paulo", é quente e úmido (Prefeitura Municipal de Votorantim,1986). A temperatura média anual aumenta de leste para oeste e varia de 17

$\mathrm{C}$ a $20 \mathrm{C}$. A temperatura média de janeiro é de $21 \mathrm{C}$ a $24 \mathrm{C}$, e de julho varia de $10 \mathrm{C}$ a 12 C. A ocorrência de geadas é de até cinco dias no ano.

As precipitações médias anuais totais são maiores a Leste e estão entre $1200 \mathrm{~mm}$ a $1500 \mathrm{~mm}$ e deste total em média $45 \%$ estão concentradas no trimestre mais chuvoso (novembro-dezembro-janeiro). A duração do periodo seco é de até um mês.

Hidrografia

O principal rio que banha o município é o rio Sorocaba, sendo seus principais afluentes o rio Cubatão e o Ipaneminha.

População

A população atual e taxa de crescimento médio nos anos censitários de 1960 , 1970,1980 e 1991 e estimativa de população para 1998 constam na tabela a seguir: 
Tabela 1. Evolução populacional e taxa de crescimento do município de Votorantim, SP.

\begin{tabular}{|l|l|l|}
\hline ANO & População Total & Taxa crescimento \\
\hline 1960 & 17.347 & - \\
\hline 1970 & 26.937 & 0,96 \\
\hline 1980 & 53.147 & 2,62 \\
\hline 1991 & 80.728 & 2,50 \\
\hline 1998 & 98.277 & - \\
\hline
\end{tabular}

Fonte: Prefeitura Municipal de Votorantim (1996)

\section{Elementos de Formação Histórica}

Segundo a Prefeitura Municipal de Votorantim (1996), a ocupação européia teve início na Serra de São Francisco, contraforte ou sucessão de serras pertencentes à Paranapiacaba. Caminhos dos índios (oiabirú) ou "caminho do Sol", era a rota que demandava ao sul do pais, tornando-se rota do bandeirantismo. O primeiro habitante, Pascoal Moreira Cabral, genro de Baltazer Fernandes (fundador de Sorocaba), teria vindo antes deste, ao que consta, por volta de 1640. Na chamada Casa Grande (Fazenda São Francisco), no Itapeva (pedra chata em tupi-guarani), inicia a era rural (plantação da cana) e uma primeira moenda. Em 1645 nasceria seu filho homônimo que fundaria Cuiabá (18/04/1719). Com o ouro vindo dessa região, passariam a adquirir glebas de terra na região. Na sucessão de compras e vendas, essa fazenda passaria para o capitãomór Manoel Fabiano de Madureira e desde para sua descendência (Benjamim Madureira1830) que em 1884 vende para o Banco União. Este aproveitando o potencial hidroelétrico dá início a chamada fase industrial (advento da fábrica de chitas) .

Da fase artesanal (extração de calcáreo e mármore), no final do século passado, a tecnologia importada da Inglaterra substitui àquela. Tem início a era industrial (tingimento de tecidos), posteriormente alarga-se a empresa com fiação e tecelagem. Pode-se dizer que a partir da aquisição da massa falida do Banco União pelo então 
Comendador Antônio Pereira Inácio, teria início uma nova fase complementar, a tecnológica. A construção da via férrea alarga a abertura de um distrito totalmente industrial. Casando-se a filha de Pereira Inácio com um engenheiro pernambucano (José Ermírio de Moraes) em 1925, já começam os estudos para a exploração de pedreiras e a implantação de uma fábrica de cimento (Fábrica de Cimento Votoran, 1936). Daí para a frente têm-se a expansão do atual Grupo Votorantim (Prefeitura Municipal de Votorantim, 1996).

A partir de 1912, o vilarejo passa a distrito de Sorocaba. Na década de 40 começa a migração, fundindo-se com a imigração italiana cuja origem é de 1884 (construção da fábrica de chitas). Essa migração acelera-se à partir do término da 2. Grande Guerra. Nasce então a Fábrica de Celulose Votocel (1951) e com esta alargam-se os bairros periféricos. Dos bairros pioneiros maiores (Chave, Barra Funda - vilas industriais, Voçoroca, Itapeva e Rio Acima) a migração formaria mais de 30 núcleos originários destes. Na década de 60 já não há condições para Sorocaba cuidar de um distrito com mais de 30 bairros dispersos. Em 1963, no dia 01 de dezembro, um plebiscito marca o início de uma nova realidade, a emancipação. No dia 27 de março de 1965 é instalado oficialmente o novo município (Prefeitura Municipal de Votorantim, 1996). 


\section{RESULTADOS E DISCUSSÃo}

\subsection{Uma cachoeira com história}

A primeira referência histórica encontrada em relação à área é a descrição feita em 1819 pelo naturalista francês Auguste de Saint-Hilaire, contida no livro "Viagem à Província de São Paulo"

"Em companhia de Sellow e do Ouvidor de Itu, fiz um passeio bastante agradável, apesar da chuva que desabou sobre nós. Fomos visitar, a uma légua acima de Sorocaba, uma cascata formada pelo rio do mesmo nome, mais bonita ainda que a de Itu. Após descrever uma curva fechada, o rio se despeja de repente de uma altura considerável, caindo sobre um amontoado de rochas. As águas espirram, espumantes, e logo e, seguida escoam mansamente por entre as duas margens cobertas de matas virgens. Enormes árvores estendem seus ramos por sobre a cascata, abaixo dela há uma ilhota de vegetação onde se vêem alguns arbustos, percebendo-se por entre os ramos, em um dos lados, um pequeno filete de água, que se desvia do rio e faz girar a roda de um moinho." (Saint-Hilaire, 1976, p. 195):

Esta parte do texto termina com uma nota de rodapé, onde se colocou o seguinte:

""Existe a 1 légua da cidade de Sorocaba, no rio do mesmo nome", diz Varnhagem, "uma queda d'água de cerca de 300 pés ingleses, à qual é dado o nome de Salto de Vuturaty. O rio Sorocaba tem 200 pés de largura e é interrompido por várias outras cascatas menores; entretando, ele apresenta longos trechos onde suas águas fluem suavemente e ele se torna perfeitamente navegável. $\mathrm{Na}$ sua margem direita formou-se uma imensa furna cuja abóboda é ornada de estalactites, a qual é chamada de Palácio pelos moradores do lugar"(Beobachtungen, etc., in Eschwege, 
Journ., II). É possivel que Vuturary venha de itu, cascata, ra, coisa que parece, e ty, brancura (Ruiz de Montoya, Tes. guar., 164 bis, 385, nome sem dúvida dado a essa queda d'água devido à altura de sua espuma."'"(Saint-Hilaire,1976, p. 195).

Conforme foi observado, já nessa primeira referência consta a existência de uma roda d'água primitiva, indicando a ocupação da área e o início da exploração das força das águas como fonte de energia.

A primeira documentação iconográfica conhecida da cachoeira e do município de Votorantim é o quadro "Salto de Buturantim, Sorocaba", aquarela sobre papel medindo $17,5 \times 23,5 \mathrm{~cm}$, feita pelo pintor ituano Miguel Arcanjo Benício de Assunção Dutra, conhecido como Miguelzinho Dutra. O quadro faz parte do acervo do Museu Paulista da Universidade de São Paulo. Nascido em Itu no dia 15 de agosto de 1810, Miguelzinho é considerado como juntamente com Hércules Florence, Jean-Baptiste Debret e Adrien Taunay uma das fontes preciosas de documentação iconográfica paulista do século XIX e um dos precursores das artes plásticas no Brasil. Autodidata, foi o introdutor da pintura de cavalete no Brasil, enfocando cenas de rua, tipos e costumes populares, igrejas e paisagens naturais (MASP, 1981).

Artista de múltiplas facetas, um artigo de Aluísio de Almeida (Monsenhor Luis Castanho de Almeida, historiador de Sorocaba) publicado no "Correio Paulistano" de 09 de abril de 1954, fez um perfil de Miguelzinho, com base em um artigo do jornal "O Piracicabano" de 22 de setembro de 1896:

“...Está ainda na memória de todos o que foi Miguelzinho, e os relevantes serviços que durante 30 anos prestou a esta terra. Ativo, inteligente trabalhador, era versado em quase tudo: bom ourives, pintor, escultor, arquiteto, bom músico, excelente organista; bom latinista, versado em teologia, reunindo a todos estes dotes a mais fina educação. O seu culto, porém, mais fervoroso, o seu fanatismo, era a caridade. Que o digam os pobres, cujas lágrimas vivia a enxugar! Como político liberal extremado, era a imagem veneranda 
da virtude cívica! Ninguém como ele provou maior isenção, maior hombridade de princípios, maior elevação de caráter. Por isso, sem ódios e sem ambições, austero, quase magnânimo, logrou o grandioso intento de passar, como passou, íntegro e ileso, e o que é mais, adorado e respeitado por entre corrilhos dos pobres partidos da nação! A morte prostrou-o quando ele ia talvez a meio da sua gigantesca obra de sacrificios e de sagrado entusiasmo - a sua querida Igreja da Boa Morte, hoje abandonada pela descrença dos homens, alterando o olvido do repúdio..."(MASP,1981, p.20-22).

É citado também que o primeiro museu do Estado de São Paulo foi organizado por Miguelzinho em sua casa de Piracicaba, contendo no acervo objetos raros, amostras de minerais, armaduras, animais empalhados, esqueletos montados, armas e utensílios indigenas, selos, pinturas e desenhos. Após a morte de Miguelzinho, o museu foi disperso pela família, vendido a particulares, restando apenas o núcleo de desenhos e aquarelas que pertencem às coleções iconográficas do Museu Paulista. Maiores detalhes sobre a vida e obra de Miguelzinho encontram-se na tese de doutorado de Arquimedes Dutra (bisneto do mesmo) intitulada "A Contribuição de Piracicaba na arte nacional", defendida na Escola Superior de Agricultura Luiz de Queiroz da Universidade de São Paulo em 1972 (MASP, 1981). Miguelzinho faleceu em Piracicaba a 22 de abril de 1875.

O quadro "Santo de Buturantim, Sorocaba" foi pintado provavelmente entre 1835 e 1845, mostrando uma vista da cachoeira e seu entorno, onde se destaca uma vegetação exuberante nas encostas (hoje em sua maior parte desmatadas) e a ocupação humana já existente, como uma casa grande e duas menores próximas, bem como área cercadas (piquetes). Destaca-se junto as casas a presença de três pinheiros-do-paraná (사aucaria angustifolia), espécie que a princípio não ocorre nos remanescentes florestais da região. Mostra-se também a ocorrência de desmatamento em morro situado no lado esquerdo do quadro, hoje conhecido como "Morro do Macuco" onde se situa a estação de tratamento de água central (ETA) do Serviço Autônomo de Água e Esgoto de Votorantim. Também em primeiro plano, no canto direito inferior, observa-se a presença de tocos de árvores, devendo a área ter sido recentemente desmatada. 
Segundo uma reportagem do jornal local "Folha de Votorantim" de 18/03/78, p. 03, intitulada "Votorantim se interessa pela sua história e vai preservar a paineira", onde foi citado pela primeira vez ao público local a existência do quadro de Miguelzinho Dutra, onde o então presidente da Câmara, José Moacir Abbad e o diretor da Câmara, Edson Veronese, estiveram em São Paulo junto à Fundação de Pesquisa do Museu Paulista onde fotografaram o referido quadro, citando-se que a casa retratada seria do primeiro morador de Votorantim, Porfirio Machado. A paineira citada na reportagem seria a retratada no quadro e que ainda existiria no bairro da Chave, porém cabe destacar que as árvores isoladas retratadas, pelo tipo de arquitetura de copa são sem dúvida araucárias e não paineiras.

Caberia destacar que nessa reportagem foi colocado ao público a primeira iniciativa oficial relativa a área da Cachoeira e seu potencial: o então prefeito, Luiz do Patrocínio Fernandes nomeou uma comissão composta pelo presidente da Câmara, José Moacir Abad, pelo Diretor de Contabilidade da Prefeitura, Wilson Menna e pelo diretor de Promoção Social, Cândido dos Santos. Os objetivos dessa comissão eram realizar estudos para valorizar e recuperar uma velha paineira existente nas proximidades da Cachoeira, prevendo-se o cercamento do local e implantação de um pequeno jardim com uma placa e busto do primeiro morador da cidade, Porfirio Machado, assim como "deverá ainda estender seus estudos sobre a viabilidade de aproveitar como área de lazer e de turismo a Cachoeirinha, também localizada no bairro da Chave" (Folha de Votorantim, 18/03/78, p.3). Não temos conhecimento dos resultados dessa primeira tentativa conhecida de estudo para utilização da área da cachoeira, assim como não foi protegida a paineira histórica citada.

Essa movimentação feita pela imprensa local foi motivada pelo corte pela Prefeitura de uma paineira histórica existente nas proximidades da Cachoeira, que estaria oferecendo risco ao escritório da empresa de ônibus urbanos Votur, que se instalou no local (ao lado da Cachoeira, pátio, garagens e escritório), conforme reportagem publicada na Folha de Votorantim em 11/03/78 em primeira página: "Morre parte da nossa história. Cortada uma das esquecidas paineiras". Finalmente, em 21/10/78, na mesma Folha de 
Votorantim, p.01, reportagem destaca: "O triste fim da última das paineiras", que vale uma citação integral:

"A forte chuva com vento que caiu sobre a cidade terça-feira à tarde, além de causar muita erosão pelas ruas de terra fez uma vítima histórica: derrubou a última das três paineiras do bairro da Chave, remanescente dos primórdios da povoação de Votorantim, no século passado, ao tempo em que Porfirio José Machado ali morava e mantinha uma beneficiadora de algodão.

Esquecida por todos em vida, a derradeira árvore, monumento de uma época, também foi ignorada na hora da morte. $\mathrm{E}$ tombou sete meses após sua companheira histórica ter sido cortada, sob alegação de que poderia cair sobre o escritório da Votur ali instalado, nas proximidades da cachoeirinha. A última paineira, já carcomida pela idade pelo descuido, mas ainda bastante verde, não resistiu ao vento, rachando-se na bifurcação do tronco. A perda passou ignorada pela população e autoridades, ficando os galhos caídos à beira da estrada, ao final da rua Asdrúbal Nascimento, ponte de acesso à garagem da Votur e à Estação de Tratamento de Água.

Agora só resta o tronco despido, condenado, com uma fenda central, como último marco vivo de toda uma época. Quando foi derrubada a outra paineira, em março deste ano, a Prefeitura chegou a nomear uma comissão que cuidaria da preservação da outra árvore e do melhor aproveitamento do local. Mas nada foi feito de concreto" (Folha de Votorantim, 21/01/78, p.01)

A primeira referência sobre a denominação dada pelos indígenas àquela queda d'água foi nos dado por Saint-Hilaire (1976, p. 195):

"é possivel que "Buturaty" venha de Itu (cascata), ra ( coisa que parece) e ty (brancura), pela decomposição da palavra a mesma 
feita, nome que certamente foi dado a essa queda de água, por causa da alvura de suas espumas".

Fontes (1997), memorialista local, fez as seguintes observações em relação às variações que terminaram em "Votorantim":

""Em razão da variação dos dialetos indígenas (tupi-guarani) na mescla de tribos que usaram a Serra de São Francisco como "Piabirú" ou "caminho do sol", Buturaty, Botu-ra-ti, Ibitirantim, trazem a tradução para "águas de espuma que caem", que tal a própria defasagem provocada pelos caboclos no nome da cidade, o significado sofre alterações ns tradução: "Cascata Branca". O índio não conhecia a palavra "cascata", mas a expressão "cair". Pode até ser "espuma branca que cai", ou definições parecidas. No próprio dicionário tupi-guarani, cada pedaço de palavra de "Botu-rá-ti" tem um significado: "Botu"(água), Rá (do verbo "cair") e finalmente "Ti", que seria uma rocha jorrando água. Curiosamente uma rocha em forma de nariz. $\mathrm{O}$ índio usava muitas comparações com os órgãos humanos, como também nos atos naturais humanos. Assim é comum encontrar traduções, que colocamos "despejar, despencar, jorrar"quando seria "urinar, mijar",etc. Esta última expressão é a mais normal no linguajar indigena. Nós é que procuramos adaptar par não ficar uma tradução esquisita. Imagine uma tradução ao pé da letra de "Itupararanga" como "mijo grande e barulhento". Preferimos algo mais suave e poético: "águas barulhentas..."'(Fontes, 1997,Folha de Votorantim, 24/05/97, p.09).

Um outro artista plástico que retratou não só a Cachoeira como os primórdios da ocupação humana em Votorantim foi Ettore Marangoni. Nascido na Suiça, em Baar, Cantão de Zug em 29 de junho de 1907, chegou ao Brasil aos 08 anos de idade, em 1915, vindo residir no então distrito industrial de Votorantim, município de Sorocabana época. Aos 12 anos já pintava pequenos quadros. Em Votorantim fez seus estudos iniciais, desenhando rostos de amigos e de pessoas que conhecia. Aos 15 anos, como o pai já 
trabalhava na Votorantim S/A Indústria Têxtil, na seção de gravação. Ali, como continuava desenhando todos que conhecia, acabou despertando a atenção de um dos diretores, sendo levado para São Paulo para fazer curso de técnica de gravura de tecidos, aproveitando o tempo para estudar no período noturno da Escola de Belas Artes.

Marangoni ficou então 06 anos em São Paulo, indo trabalhar como mestre de gravação na América Fabril, no Rio de Janeiro, tendo a oportunidade de aperfeiçoar seus conhecimentos na Escola Nacional de Belas Artes. Voltou para Sorocaba em 1942, contratado pela Cianê-Companhia Nacional de Estamparia, já casado com dona Iria Picolloto Marangoni, produzindo belas telas porém ainda sem qualquer conotação histórica. No final dos anos 40 , começou a demonstrar interesse por conhecer mais a fundo a história de Sorocaba e também do então distrito de Votorantim, onde vivera parte da infância. Um vizinho fez cair em suas mãos alguns escritos assinados por Aluísio de Almeida, representando detalhes da fundação de Sorocaba e de outros aspectos da história de Sorocaba, acrescentando a informação de que Aluísio de Almeida era na verdade um sacerdote católico, o cônego Luiz Castanho de Almeida.

Alguns dias após Marangoni esteve na residência do padre-historiador, comunicando seu interesse pela história da cidade e a intenção de produzir algum quadro retratando aspectos da história de Sorocaba, no que foi bem recebido pelo mesmo. Em 1951, nas vésperas das comemorações dos 300 anos da fundação de Sorocaba (1954), Ettore Marangoni, orientado por padre Castanho, iniciava a produção da sua primeira tela histórica, a mais festejada e conhecida de sua vastíssima obra que viria pelas quatro décadas seguintes: "A Elevação de Sorocaba à Vila". Seguiram-se então uma seqüência de telas retratando aspectos curiosos e importantes da história de Sorocaba e Votorantim. Por ter passado parte de sua infầncia e adolescência em Votorantim, tinha pela cidade um carinho especial e uma preocupação expressa em uma reportagem do jornal "Cruzeiro do Sul" : de 03/10/89 intitulada "Ettore Marangoni, aos 82, decide deixar de pintar":

"A história de Votorantim está se perdendo. Votorantim foi uma vila muito interessante e folcloricamente tem uma história que deve ser preservada e registrada para a posteridade" (Jornal Cruzeiro do Sul, 03/10/89, Caderno Mais Cruzeiro, p.05). 
Em sua casa na época, Marangoni tinha em uma parede uma tela grande que mostrava parte de Votorantim nos tempos antigos, com os armazéns, a velha igreja e o cinema e o mesmo comentou:

"Quando olho para esse quadro, lembro a minha infầncia, de quando jogava bola na rua com meus amigos, da igreja onde fiz o catecismo" (Jornal Cruzeiro do Sul, 03/10/89, Caderno Mais Cruzeiro, p.05).

A obra que mais representou o carinho por Votorantim, devido às lembranças de sua infầncia, talvez seria a tela que retrata a centenária paineira que existiu até 1978 no bairro da Chave (próxima a Cachoeira), sendo representada no quadro em sua fase final de vida, abrigando galinhas e cabras no oco do seu tronco .

$\mathrm{Na}$ mesma reportagem, o artista demonstrou aborrecimento ao tentar visitar o museu de Votorantim num domingo e encontrá-lo fechado:

"Votorantim é uma cidade operária, o povo só tem tempo para passear aos domingos. O museu poderia ser uma atração". Recordou também: "Batalhei muito com o povo e Câmara de Votorantim para que o município tivesse um museu, porque uma cidade tem elementos históricos de suma importância e poderá perdê-los se não souber preservá-los (Jornal Cruzeiro do Sul, 03/10/89, Caderno Mais Cruzeiro, p.05).

A Prefeitura de Votorantim adquiriu as obras de Marangoni, que atualmente se encontram expostas no Museu Municipal, anexo ao Centro Cultural. Entre as cerca de 18 obras expostas, destaca-se a obra "Cachoeira de Votorantim", pintada em 1970, que mostra a queda d'água. A citada reportagem do jornal "Cruzeiro do Sul" de 03/10/89 cita também que a que seria a última obra de Marangoni, "A visita do Imperador Dom Pedro II e da Imperatriz dona Tereza Cristina à Cachoeira de Votorantim", também adquirida pela Prefeitura segundo a reportagem, seria incluída no acervo do museu. A mesma atualmente está em poder de um ex-assessor jurídico da Câmara, que alega ter adquirido a mesma em caráter particular. Essa tela seria também uma das últimas de que Aluísio de Almeida teria participado com Marangoni da concepção, o que potencializa seu valor histórico, tendo sido pintada no final da década de 70 (Aluísio de Almeida faleceu em 28 
de fevereiro de 1981), conforme reportagem publicada pelo jornal "Diário de Sorocaba" de 03/03/1999 (Suplemento Especial), da qual extraímos os trechos de interesse:

"A primeira visita do jovem Imperador D. Pedro II a Sorocaba em março de 1846 foi feita sem a presença da Imperatriz, pois ainda não existia a estrada de ferro. O imperador voltava do Rio Grande do Sul com a Imperatriz dona Tereza Cristina, desembarcando em Santos com muitas festas e subiram de carruagem até São Paulo, onde ficou dona Tereza Cristina. O Imperador. acompanhado de sua comitiva, veio a cavalo, percorrendo o então interior da Província - São Roque, Sorocaba, Porto Feliz, Itu e Campinas . (...) .Dia 28 ou 29, (março de 1846) fez visitas o Imperador, por exemplo, aos conventos de São Bento e Santa Clara, assistiu missa e, à tarde, com grande séquito, foi visitar o "Salto de Votorantim", a alguns quilômetros da cidade.(...) Dom Pedro II e dona Tereza Cristina vieram em 1875, 1878 e 1886 (novembro) de trem. Já não visitavam conventos, mas o Gabinete de Leitura Sorocabano, as escolas, a máquina de beneficiar algodão de Luiz Matheus Mailasky, a fábrica de tecidos do Fonseca (em 1886) e sempre a cachoeira de Votorantim e Ipanema.

O quadro bem interpretado por nosso pintor Ettore Marangoni retratata a visita de 1886 . Os Imperadores foram de carruagem, bem como os ricos comerciantes sorocabanos, como o Magalhães, português da rua Sete de Setembro. Só foi a cavalo, organizando o ... tráfego, o sargento Felipe Santiago, voluntário da guerra do Paraguai, sorocabano." (Diário de Sorocaba, 03/03/99, Suplemento Especial, p.06).

Marangoni recebeu muitas homenagens em vida, como o troféu Tropeiro recebido em 24/06/83 nas comemorações dos 80 anos do Jornal Cruzeiro do Sul, promovido pela Fundação Ubaldino do Amaral, recebeu o título de cidadão votorantinense da Câmara 
Municipal de Votorantim em 1990. Sua última obra foi "Capela do Bairro do Ipatinga", de 1992. Faleceu em 07 de dezembro de 1992, aos 85 anos.

Cabe destacar que, em 1991, vários integrantes do Grupo Ecológico Cascata Branca estiveram em visita a Ettore Marangoni em sua residência, em Sorocaba, entre eles o autor. O motivo da visita era a publicação de um artigo do memorialista local, Paulo Fontes, intitulado "Botu-rá-ti ou Cascata Branca" publicado no Jornal "Cruzeiro do Sul" de 91 (data não disponível), onde o mesmo afirmava que a cachoeira Votorantim não seria aquela no bairro da Chave e sim outra onde foi construída a barragem da Represa Itupararanga, em 1914, do qual destacamos alguns trechos:

"Numa síntese disso tudo que foi estampado em centenas e centenas de linhas, podemos afirmar que o nome Votorantim não nasceu na cachoeira conhecida como da "Chave". Ela é simplesmente um apêndice da verdadeira "cascata branca", que situou-se no Sítio Itupararanga. (...) Louvável os jovens lutarem pela preservação da cachoeira da Chave, mas temos que nos apossar em termos de história e de conservação do traçado geográfico, que nasce após o paredão. (...) Cessou o barulho com a barragem, secaram as espumas e o caminho dos índios se apagou. Mas o rastro permanece. As marcas continuam para a preservação da identidade. Muito mais para corrigir os "desvios"históricos que o comodismo político fabrica. Ou permuta. Preservemos a cachoeira da Chave. Filha de Itupararanga" (Fontes, Folha de Votorantim, s.d., 1991, p.29)

Sendo bem recebidos, o próprio Marangoni afirmou que "aquele rapaz" (referindo-se ao memorialista Paulo Fontes) estava enganado, pois ele passou parte da infância ao lado da Cachoeira, inclusive retratando-a em 1970. Todas as citações históricas e pictóricas (Saint'Hilaire, Miguelzinho Dutra) comprovam ser a cachoeira do bairro da Chave como sendo a cachoeira que originou o nome da cidade. A distância de uma légua e meia entre Sorocaba e a Cachoeira citada por Saint'Hilaire também 
corresponde a distância aproximada, considerando-se que as estradas tinham um aspecto mais sinuoso no século XIX.

Fontes (1997) em artigo publicado na Folha de Votorantim de 24/05/97 intitulado "A Cachoeira que denominou a cidade" praticamente contradiz esse outro artigo de sua prórpia autoria de 91 publicado no jornal "Cruzeiro do Sul", desta vez sintetizando os relatos de Saint'Hilaire, de Aluísio de Almeida (visitas da comititiva da Família Imperial de $1846,1875,1878$ e 1886), já citadas, e também do historiador Antônio Francisco Gaspar:

"Há pouco mais de um século que o Salto de Votorantim foi sempre uma das mais lindas cachoeiras existentes no rio Sorocaba. Também aquele lugar foi no tempo de dantes um dos mais belos e apraziveis passeios nos arredores de Sorocaba. A natureza com perfeição deu àquele lugar tudo quanto possui de elevado e digno de admiração. Ali as árvores copadas e frondosas, cobertas de variedades de flores e parasitas diferentes eram e faziam daquelas matas, a mais formosa habitação de ninfas mitológicas dos bosques, montes, fontes e quedas d'água" (Fontes, 1997, Folha de Votorantim, 24/05/97, p.09).

Destaca-se nesse artigo de Fontes (1997), além da síntese dos relatos que indicam a cachoeira da Chave como "Buturaty", a importância de recuperar a área onde a mesma se insere:

"Sua importância é sentida muito mais na distância, do que mais propriamente no âmago que é Votorantim. Ou mais precisamente, num bairro operário do final do século passado. Talvez que pelo cunho histórico que representa, a nossa cachoeira da chave seja vestida a rigor a adentrar no novo século. Será mais que um projeto, será um marco histórico para saudar o novo milênio. Uma gratidão a uma queda d'água que fez o Imperador e autoridades de um reino que fomos, chegar até suas margens. Coisa talvez, que os que reinam talvez nem conheçam toda sua extensão 
histórica. Até mesmo a geração atual não saiba dirigir-se até ela (...)"' (Fontes, 1997, Folha de Votorantim, 24/05/97, p.09).

Ainda no aspecto histórico, caberia destacar a inclusão da Cachoeira Votorantim como um dos pontos de destaque, dessa vez contida na documentação fotográfica da "Commissão Geographica e Geologica do Estado de São Paulo", contida na publicação "Exploração da região comprehendida pelas folhas topographicas Sorocaba, Itapetininga, Bury, Faxina, Itaporanga, Sete Barras, Capão Bonito, Ribeirão Branco e Itararé" que esteve percorrendo a região entre 1914 e 1927 (Commissão Geographica e Geologica, 1927). Embora não haja citação na parte documental daquela queda d'água, a mesma foi fotografada, mostrando o entorno da mesma porém devido a proximidade e falta de nitidez não é possível visualizar a ocupação do entorno, se existia ainda vegetação significativa na encosta ou não.

Artistas locais também retraram a Cachoeira, apenas em uma escola (Escola Municipal de Ensino Fundamental "Abimael Carlos de Campos") existem dois quadros, um de autoria desconhecida e outra da familia Terciani mostrando a área, apresentados na exposição do "Projeto Cascata Branca" em 03/12/99, onde os alunos de $1^{\circ}$ a $4^{\circ}$ série apresentaram os resultados de um amplo projeto de pesquisa histórica sobre o município.

A Cachoeira também inspirou poetas e músicos. Segundo Fontes (1997):

"" o professor graduado em música, Ochelsis Laureano, falecido recentemente na cidade de Salto, enalteceria com poesia e instrumental, os encantos da cachoeira:"Deixe a cidade formosa morena, linda pequena e venha para cá; rever as matas e rios, nas cachoeiras do seu passar"... E continua num estribilho: "...e as águas a rolar, chuá...chuá...chuá...e a fonte a gemer chuê...chuê...chuê...Parece que alguém que é natureza fez esta beleza prá gente olhar..." "(Fontes, 1997, Folha de Votorantim, 24/05/97, p.09). 
Outra manifestação poética abordando a Cachoeira, desta fez de uma poetisa local, Ivani Evaristo, foi publicada em 01/03/97 na Folha de Votorantim:

\section{"Meu querido Votorantim}

Sou teu filho, mas...

Para falar de você

Pedi ajuda a querubins

Não é fácil descrever tuas belezas

Meu querido Votorantim.

Quando você era Botura-ti com um céu encantador Teve como visitante

D. Pedro II o Imperador.

O teu nome foi registrado

Como se registra criança

no coração está gravado

Querida "Cascata Branca"

(...) (Evaristo, 1997, Folha de Votorantim, 01/03/97, p.11)

Outro fato bastante interessante é que o ufanista Hino Municipal, de autoria de Lecy de Campos, mesmo indiretamente, faz menção aos "fluviais recantos", provável referência à área da Cachoeira, e as indústrias que impulsionaram o crescimento:

"Hino de exaltação à Votorantim

Minha terra tem encantos,

Tem belezas naturais,

Tem jardins, fluviais recantos,
Nossas indústrias tem potência, Tem igrejas p'ra os fiéis, Tem escolas, luz da ciência, 
$\mathrm{E}$ riquezas minerais

Sons de máquinas, usinas

$\mathrm{E}$ de águas a rolar,

Em sussurros de surdinas,

Pelo espaço a reboar.

Chaminés que fumegantes,

Estão sempre a evidenciar,

As indústrias operantes,

Que engrandecem o lugar.

Côro

O seu solo é manancial,

Fonte de riquezas mil,

O seu clima é tropical,

É um pedaço do Brasil.
No esporte tem lauréis.

São acordes de vitória, Num arcano musical, Proclamando a sua glória, E pujança sem igual.

Onde um povo exuberante, Que labuta sem cessar, Construiu esse gigante, Portentoso e singular."

Além das referências indiretas, um fato que chama a atenção no Hino é a associação entre as 'Chaminés fumegantes" e riqueza, progresso, calcado na forte industrialização.

Além dessas manifestações, observamos também que a imagem da Cachoeira sempre foi utilizada para a divulgação do Município, principalmente por parte da própria administração.

Seja na forma de simples postais, calendários, seja na forma de folhetos mais elaborados para fins de divulgação, a Cachoeira, quando não é o destaque principal é citada como potencial turístico. Também na home-page da Prefeitura na Internet, montada com base em um folheto, a imagem da Cachoeira e sua importância histótica é citada, embora que exista um erro grave ainda não corrigido nas páginas da home-page, 
com uma foto da cachoeira da Vila da Light, o Salto de São Francisco, sendo confundido com a cachoeira da Chave, a que denominou a cidade.

Constatamos que inclusive o próprio Grupo Votorantim já se utilizou da "imagem" da Cachoeira, através do reprodução do quadro de Miguelzinho Dutra na capa e contra-capa do relatório anual de atividades do ano de 1982, reconhecendo a importância do patrimônio ambiental que inspirou a própria denominação do Grupo.

Destaca-se ainda em Votorantim a atual existência de um grupo de poetas e artistas locais que formaram a "Ação Cultural Botura-ti". Esse grupo reúne-se periodicamente e apresenta seus trabalhos em eventos, coordenados por André Damazio. Lançaram vários folhetos com poesias e inclusive um folheto ("Entupindo"), elaborado por Damázio (sem data), contendo noções básicas sobre o idioma tupi (gramática e ortografia). Destacamos a poesia em tupi -português de Damázio (Folha Corrida, Ação Cultural Botura-ti, sem data):

\section{"Yturantinga-pe?}

Votorantim?

Akûeî-pe, asé anama o-îkobé katu...

Ali a familia da gente vivia bem...

Asé tatá ypy-pe o-guapyk,

A gente sentava perto do fogo,

o-petymb-u pety'-tinga-

fumava-se uma fumaça branca -

Asé o-petymb-u petyma ting ' $y$ tu' ' $y$ îa.

Fumava-se uma fumaça tão branca como a água da cascata.

Taba kunum i 'ytu ting-a r-upi o-gûatá...

As crianças da aldeia pelo branco da cascata caminhavam.

Aipo ‘ara r-esé, peró gûasem-a r-enondé,

Naqueles dias, antes da chegada dos portugueses, 
Asé o-îkobé katu, 'y-bo, ka'a-bo, kó-bo-

A gente vivia bem, pelo rio, pela, pelas roças-

asé o-îkobé-eté,gûasem-a s-enondé.

a gente vivia muito, antes da chegada deles.

Peró mba'e-mba' e o-î-me'eng asébe:

Os portugueses deram muitas coisas pra gente:

-Tupinakyîa pereba akûei ‘ara r-esé o-ypi

As feridas tupiniquins naquele dia começaram

a'e posanong-a o-nho mim.

e a cura esconderam.

'Ang, îandé taba 'ytu-tinga o-îkó-é:

Agora, a cascata-branca de nossa aldeia é diferente:

-'ang, a'e 'Ytu-ran-tinga, Votorantim.

Agora, ela é a Falsa Cascata Branca, Votorantim.

A'e, îandé anama, petyma pyter-i, o-kanhem...

E nossa familia, no meio da fumaça, sumiu..."

(Damázio, s.d.)

A beleza da Cachoeira que inspirou o nome da cidade também é lembrada quando da ocorrência de desfiles cívicos, seja na forma de faixas/cartazes, seja na forma de carros alegóricos, por parte da comunidade escolar local. A cachoeira também é sempre lembrada em eventos culturais escolares, na forma de painéis, cartazes e desenhos.

A cidade de Votorantim conta com um Grupo Escoteiro que para sua denominação escolheu o nome "Vuturaty", em referência à Cachoeira que originou o nome da cidade. Esse Grupo também tem participado de eventos e atividades ligadas ao meio ambiente em parceria com a Prefeitura, como plantios comemorativos no Dia Mundial do Meio Ambiente e de trechos de tentativas de recomposição da mata ciliar do rio Sorocaba na área urbana. 
Mais recentemente, constatamos que uma imagem da cachoeira foi incluída no calendário-revista educativo do ano 2000 e de divulgação da Polícia Florestal e de Mananciais, que dedicou-se aos recursos hídricos. Embora conste a imagem da cachoeira junto ao mês de abril, não existe uma chamada ou legenda que a identifique como tal, estando na página destinada ao rio Sorocaba (Polícia Florestal e de Mananciais, 2000).

Do conjunto de representações compiladas de várias fontes pelo autor a respeito da área da cachoeira Votorantim, fica comprovada sua importância enquanto patrimônio histórico, cultural e ambiental da cidade e sua potencialidade de uso futuro como espaço de cultura e lazer. Apesar da referência constante da área inclusive por parte da Prefeitura, não tivemos uma atuação até o momento efetiva para a recuperação ambiental e revitalização cultural da área.

\subsection{Resgate da história do Grupo Ecológico Cascata Branca}

A presente reconstituição da história do Grupo foi feita a partir da análise dos materiais arquivados em poder do autor, cedidos pela Escola que o sediou e exintegrantes, bem como pesquisa junto a outras fontes, principalmente reportagens nos jornais locais e regionais.

Podemos colocar o surgimento do Grupo Ecológico Cascata Branca como uma associação de interesses coincidentes.

No dia $03 / 01 / 90$, o autor e Laura Jane, moradora de Votorantim e também acadêmica de Engenharia Florestal, agendaram uma reunião com o Prefeito Municipal para expor a idéia de um projeto que objetivasse recuperar a área da Cachoeira e transformá-la em uma área de lazer, sendo bem recebidos pelo Prefeito da época em seu gabinete. Foi agendada uma reunião entre a Chefia do Departamento de Ciências Florestais da ESALQ e representantes da Prefeitura, que seria realizada no ESALQ tendo como objetivo a viabilização de um convèncio do tipo "guarda-chuva" para encaminhar a proposta de implantação do Parque da Cachoeira, porém os técnicos da Prefeitura não compareceram a essa reunião, sem justificativas claras. Em virtude dos compromissos acadêmicos do autor na época, nada pode ser feito de prático naquele momento. 
Coincidentemente, desde o início do ano de 1990, os alunos da 7o. série da Escola Estadual "Profa. Edith Maganini", localizada no Bairro Vossoroca, estavam empenhados em uma série da atividades ligadas à conservação do patrimônio escolar e do ambiente local, sob coordenação das professoras Ângela Maria Prezotto e Marlene Aparecida Beranger. Foram desenvolvidas várias atividades na escola, como concurso de cartazes sobre Higiene Escolar, gincanas para arrecadação de materiais de limpeza, mutirões de limpeza envolvendo alunos e seus pais e outras atividades centradas na escola. Após esse mutirão, os alunos da 7o. série A se reuniram e passaram a conversar sobre os problemas existentes no Bairro, entrando em contato com a Associação de Moradores. À partir desse contato, verificaram as conquistas da Associação e as questões pendentes, que estavam sendo reivindicadas, de onde destacou-se as obras de um Centro Esportivo, que há muito tempo estava parada. Foi a partir dessas preocupações que surgiu a idéia de se formar um grupo, para a princípio defender os interesses da Comunidade local.

Dentro desse processo, após a constatação do problema da obra parada do Centro Esportivo do Bairro, os alunos, com orientação da Professora Marlene Beranger, buscaram contato com os setores responsáveis da Prefeitura, realizando uma entrevista com o então Secretário de Educação.

Tal entrevista foi alvo de uma preparação específica, já levando uma série de questões formuladas divididas em questões gerais (o que está sendo feito em relação a educacão, o que o Secretário entende por Educação, o que vem sendo feito em relação ao menor carente, qualidade de ensino comparando as escolas públicas com particulares) e assuntos ligados a problemas locais da escola (segurança, contrução de uma sala de vídeo, necessidade de reforma do prédio, melhoria na merenda, estruturação de uma fanfarra, material para reforma do jardim (mudas/terra)). As respostas do Secretário foram transcritas e alvo de discussões internas posteriores.

Foram realizadas outras reuniões com o Setor de Cultura e Esportes da Prefeitura na época, a partir das quais fortaleceu-se a idéia de formar um Grupo.

Um elemento que contribuiu decisivamente para o estímulo da criação de um Grupo Ecológico foi a divulgação da reportagem no periódico local feita no dia 05/08/90, colocada como Manchete: "Cachoeira, um ponto de lazer e turismo, o plano dos 
estudantes"(Folha de Votorantim, 05/08/90, p.01) onde se detalha a iniciativa do autor, na época quintoanista do curso de Engenharia Florestal da ESALQ/USP e de Laura Jane Gomes, também moradora da cidade, colega de infância e acadêmica do 20. ano do curso de Engenharia Florestal de Lavras (MG). A partir de contatos informais com a Associação de Moradores local (bairro da Chave), integrantes da área de Cultura e Turismo da Prefeitura, esboçou-se um plano geral de trabalho com a intenção de unir as entidades e instituições ligadas direta ou indiretamento ao assunto, com o objetivo de viabilizar a implantação de um Parque Municipal no local, como a Prefeitura, ESALQ/USP (suporte técnico-científico), Grupo Votorantim (proprietário da área na época) e órgãos estaduais de licenciamento e controle da poluição ambiental (CETESB e DEPRN), além de outras entidades ambientalistas da região, como o NEMI (Núcleo Ecológico Morro de Ipanema), de Sorocaba, com intensa atuação na luta contra o Projeto Aramar (Projeto da Marinha de fabricação de propulsor nuclear de submarino, em instalação na cidade vizinha de Iperó)

A publicação dessa primeira reportagem foi o elemento decisivo para que os alunos da 7o. série da Escola Estadual "Profa. Edith Maganini" determinassem a criação do Grupo Ecológico "Cascata Branca" da Escola "Edith Maganini" - sigla GECBEM, cujo nome foi definido após uma eleição entre os mesmos, com data de "fundação" em 11/08/90. Sob coordenação da Professora Marlene Beranger, o núcleo original do Grupo tinha 11 alunos. Entre seus objetivos, expostos no relatório anual das atividades da Escola para a Delegacia de Ensino Local, tivemos:

"Os objetivos do grupo são:

lo. Melhorar a Escola

-Construir jardins

-lutar pela restauração do prédio

-melhorar o ambiente escolar e das moradias.

2o. Lutar pela construção do Centro Esportivo, para tirar as crianças da rua

Esperamos que as autoridades locais pensem em nós e voltem a investir em centros esportivos. Achamos que todos os Bairros 
precisam de uma área de lazer, para as crianças e adolescentes evitarem as ruas (com isto diminnuirá a marginalidade).

3o. Lutar pelo projeto de recuperação da Cachoeira da Chave, dos estudantes de engenharia Adriano Lopes e Laura Jane

-Conscientizar as pessoas sobre a importância da recuperação da Cachoeira.

4o. Estudar o problema do lixo.

-Verificar as possibilidades de reciclagem do lixo.

5o. Arborização das ruas do bairro e também do município todo.

6o. Nosso objetivo maior é melhorar a vida da população.

Esperamos que todos tomem consciência da importância de se investir em "Educação Ambiental".

Pretendemos lutar pela recuperação da Cachoeira. Entendemos que além de embelezar nossa cidade seria fundamental para o arejamento e equilibrio ecológico da região.

Esperamos que os políticos locais se empenhem no sentido de se criar um órgão voltado para a proteção ambiental. Sentimos a grande necessidade de se investir em "Educação Ambiental".

Gostaríamos de ressaltar que "Educação Ambiental" está na Constituição de nosso país. É lei defender a Ecologia." (Grupo Ecológico Cascata Branca, 1990)

Esses objetivos foram definidos pelos próprios alunos, sob coordenação da Profa. Marlene Beranger, após o primeiro contato dos mesmos com o autor e a então acadêmica Laura Jane.

Inicialmente, eram realizadas reuniões semanais em uma sala cedida pela Diretoria Municipal de Cultura, sendo que posteriormente, em função das dificuldades de acesso a esse local pelos alunos (a escola situava-se em outro bairro), as reuniões passaram a ser realizadas na própria escola. 
Uma das primeiras atividades realizadas conjuntamente (dia 26/08/91) foi a realização de uma filmagem na área da Cachoeira, com a participação do Diretor de Cultura e colaboração de um comerciante local, assim como de Gabriel Bitencourt, ambientalista sorocabano integrante do NEMI (Núcleo Ecológico Morro de Ipanema). A proposta original era utilizar o material audiovisual para trabalhos futuros junto a comunidade local (escolas, associações de bairros, escolas). Já naquela primeira atividade conjunta vislumbravam-se alguns problemas em relação à complexidade da questão ambiental local: o comerciante que efetuou filmagem, ao filmar a emissão de efluentes industriais despejados pela Fábrica Votocel (descarga junto a represa situada à montante da queda d'água), com odor característico, formação de espuma e alteração na coloração da água, comentou que "iríamos ter problemas" se mostrássemos essas imagens, numa alusão ao Grupo Votorantim, então proprietário da área. Por falta de estrutura técnica e apoio financeiro, esse vídeo não chegou a ser editado, sendo feito apenas um "clip" com cerca de 06 minutos, sem narração, com imagens da área, de problemas ambientais locais e de reportagens do grupo.

Logo após esse primeiro contato de alguns dos integrantes do Grupo com a área da Cachoeira, foi proposto a elaboração de um abaixo-assinado para ser passado junto a população visando sensibilizar as autoridades locais quanto à situação da área. Esse abaixo-assinado teve o seguinte cabeçalho:

"A PREFEITURA MUNICIPAL DE VOTORANTIM E DEMAIS AUTORIDADES

\section{ABAIXO - ASSINADO}

Nós, moradores de Votorantim abaixo-assinados, reivindicamos a elaboração de um amplo Projeto de Recuperação Ambiental envolvendo a Área da Cachoeira do Bairro da Chave, através de um Convênio da Prefeitura Municipal com a Universidade de São Paulo (Campus de Piracicaba) e S.A. 
Indústrias Votorantim. Este Projeto terá participação popular na sua elaboração e efetivação." (Grupo Ecológico Cascata Branca, 1990)

Após a coleta de assinaturas junto à comunidade estudantil e população em geral, o abaixo-assinado foi encaminhado por integrantes do Grupo para o Sr. Prefeito Municipal na época (final de agosto/início de setembro de 1990).

Esse abaixo-assinado já continha a forma de trabalho a ser seguida pelo Grupo, com base na vivência do autor e de sua colega enquanto estudantes preocupados com o aspecto não apenas "ambiental" da área, que se encontrava degradada, mas principalmente com o potencial educativo que o processo de implantação participativo poderia proporcionar, embora que de forma pouco aprofundada do ponto de vista teóricometodológico.

Seguindo esse princípio, traçou-se então uma estratégia de envolvimento de setores relacionados direta ou indiretamente ao assunto para a viabilização da implantação de um Parque Municipal da Cachoeira, através da realização de uma primeira reunião específica, que seria realizada nas dependências da Biblioteca Municipal de Votorantim. Foram convidadas através de oficios e mediante ampla divulgação na imprensa local e regional as seguintes pessoas/instituições:

- Prefeitura Municipal de Votorantim, em nome do Prefeito e Secretários Municipais;

- Representantes da CETESB (Companhia Estadual de Tecnologia e Saneamento Ambiental) e DEPRN (Departamento Estadual de Proteção de Recursos Naturais), órgãos da Secretaria de Estado de Meio Ambiente;

- Curadoria do Meio Ambiente;

-Grupo Votorantim, proprietário da área na época, através do Centro de Apoio Florestal; -Entidades Ambientalistas locais e regionais;

-ESALQ/USP-Departamento de Ciências Florestais (Professor Marcos Sorrentino); -Câmara Municipal de Vereadores;

-Associação Sorocabana de Indústrias, que naquele momento estava empenhada da efetivação de um projeto de recuperação do rio Sorocaba, formador da Cachoeira;

-Associações de Moradores; 
-Integrantes do Grupo Ecológico Cascata Branca;

-outras entidades ou público em geral interessado.

Essa reunião ocorreu no dia $14 / 09 / 90$, com a participação da maioria das entidades convidadas, com exceção da Câmara de Vereadores e Associação Sorocabana de Indústrias.

Foi feito um breve histórico sobre a iniciativa e o papel a ser desempenhado por cada um dos integrantes/entidades nesse processo, bem como definida a formação de um "Grupo de Trabalho" para o encaminhamento prático das medidas a serem tomadas. Destaca-se o fato que o representante da Prefeitura compareceu apenas no final da reunião, discursou sobre as obras de saneamento que estavam sendo executadas e manifestou "apoio" à iniciativa.

Realizou-se então no dia 20/09/90 uma segunda reunião, específica do "Grupo de Trabalho", com o objetivo de dar encaminhamentos práticos para o efetivo início dos trabalhos. Participaram representantes do Grupo Ecológico, Rotary Club de Votorantim, CETESB, DEPRN, Centro de Apoio Florestal do Grupo Votorantim, Delegacia de Ensino de Votorantim e de representante do NERI - Núcleo Ecológico Represa Itupararanga, Benedito Donizetti Alemão Packer. Discutiu-se a questão da propriedade da área e possivel andamento de um processo de desapropriação,bem como as linhas gerais do que seria o projeto,, cuja fase inicial seria a elaboração de um diagnóstico da área, envolvendo levantamentos topográficos, solos, vegetação, fontes de poluição, situação fundiária (ocupações), percepção da população e situação atual da área, na forma de sub-projetos.

Destaca-se que nenhum representante da Prefeitura compareceu à essa reunião, apesar dos convites e da mesma realizar-se nas dependências da Biblioteca Municipal, situada ao lado da Prefeitura.

Em 05/10/90 ocorreu a segunda reunião do Grupo de Trabalho, com divulgação pela imprensa local. O objetivo dessa reunião foi a exposição dos dados obtidos por cada integrante conforme detalhado na reunião anterior, sendo que o representante do Rotary tinha se incumbido de levar os resultados da reunião anterior para o Prefeito. O mesmo reiterou o "apoio" da Prefeitura à proposta, citando que a área estava em processo de 
desapropriação, porém novamente nenhum representante da Prefeitura compareceu à reunião.

Foram expostos os materiais e informações obtidas até o momento por parte do representante do DEPRN, Centro de Apoio Florestal/Grupo Votorantim, bem como feita uma exposição sobre subsídios para elaboração de projetos de Educação Ambiental pela pesquisadora da CETESB que na época encontrava-se desenvolvendo atividades no Departamento de Ciências Florestais da ESALQ/USP, Kazue Matushima.

Como encaminhamento dessa reunião, tendo em vista a necessidade do envolvimento efetivo do Poder Público, concluiu-se sobre a necessidade de uma reunião do Grupo de Trabalho com o Sr. Prefeito. Elaborou-se então uma extensa carta explicativa, encaminhada ao Prefeito e Secretariado, contendo todo o histórico sobre o surgimento da mobilização e atividades realizadas até a data, agendando uma reunião do Grupo de Trabalho com o Gabinete do Prefeito para o dia 25/10/90, com a seguinte pauta:

-Proposta de Convênio entre Prefeitura, Grupo Votorantim e ESALQ;

-Viabilização de um pré-projeto de diagnóstico amplo da área da Cachoeira;

-A possibilidade de um ou mais universitários atuarem durante o 10. semestre de 91 como residentes ou estagiários do Projeto Cachoeira;

- O apoio formal da Prefeitura e a implantação do COMDEMA (Conselho Municipal de Defesa do Meio Ambiente).

Nessa reunião, onde estiveram presentes representantes do Grupo Ecológico Cascata Branca, NERI - Núcleo Ecológico Represa Itupararanga e do Centro de Apoio Florestal do Grupo Votorantim, discutiu-se a questão da propriedade da área, onde foi colocado pelo Prefeito que o processo de desapropriação estava em andamento porém o levantamento topográfico não havia sido executado e que o Parque Municipal estava incluído no Plano Plurianual e no Plano Diretor como meta. A estimativa é de que a área estaria desapropriada até maio do ano de 1991.

Naquele momento então a Prefeitura tomou a posição que não poderia assumir nenhum compromisso até obter a propriedade da área. 
Frente essa posicionamento, o representante do Centro de Apoio Florestal do Grupo Votorantim também recuou na proposta de apoio à iniciativa, por determinações superiores, bem como na proposta de encaminhar e viabilizar um Projeto de Residência Florestal do autor dentro da proposta de implantação do referido Parque.

Teve início então um impasse que acabou por desestimular e desestruturar o Grupo de Trabalho, que não tinha condições de dar continuidade a nenhuma proposta em relação à implantação do Parque Municipal, por falta de respaldo institucional, haja visto que não existia nenhuma estrutura material ou financeira que subsidiasse o andamento da proposta.

Desta forma, as atividades do Grupo passaram a centrar-se mais no ambiente escolar e na própria capacitação interna.

Através de contatos com a Equipe de Educação Ambiental do Parque Zoológico Municipal "Quinzinho de Barros", de Sorocaba, os estudantes integrantes do Grupo Ecológico participaram do "10. Curso de Iniciação à Ecologia", no período de 05 a 09 de novembro, abordando temas como fauna e flora regional, noções sobre legislação ambiental, a questão da reciclagem do lixo e outros, por meio de atividades práticas e exposições teóricas, sendo muito bem aproveitado e motivador para os mesmos. Continuavam as reuniões semanais, com o planejamento de atividades e intervenções mais centradas na escola, como a recuperação do jardim, implantação de uma horta e outros.

Nesse período, foi discutido pelo Grupo a proposta de criação de uma "Fundação Pró-Cachoeira", com o objetivo de tentar congregar as entidades interessadas na obtenção de recursos financeiros para a implantação da proposta de criação do Parque da Cachoeira. Essa proposta de criação de uma Fundação foi levada para a Prefeitura e imprensa, juntamente com um balanço das atividades realizadas durante o ano de 1990, já observando a participação pouco efetiva da Prefeitura (reportagem publicada em 30/12/90-anexo ). Nessa reportagem, representantes da Prefeitura informaram sobre o andamento do processo de desapropriação da área e que a proposta do convênio entre a Prefeitura e a ESALQ "estaria em estudos" e de que "a administração tem interesse no assunto". 
Tem inicio o ano de 1991. Frente a falta de medidas práticas em função do posicionamento da Prefeitura e desestímulo geral do Grupo, o autor iniciou a elaboração de um amplo projeto de diagnóstico da área da Cachoeira, concluído em março do mesmo ano, detalhando todas as etapas dessa fase preliminar, com inclusive a intenção de tentar financiamento junto à potenciais entidades financiadoras. Intitulado "Implantação do Parque Municipal da Cachoeira de Votorantim com Participação da População", o mesmo foi subscrito pelas três entidades ambientalistas envolvidas: Grupo Ecológico Cascata Branca, Núcleo Ecológico Morro de Ipanema e Núcleo Ecológico Represa Itupararanga.

Bastante extenso e detalhado, o projeto tinha cerca de 46 páginas (fora os anexos - cópias de reportagens), com uma ampla introdução geral sobre a questão ambiental, um breve histórico sobre o movimento pela recuperação da cachoeira até aquela data, a delimitação dos objetivos específicos, a saber:

"-Recuperar a área da Cachoeira de Votorantim, importante patrimônio histórico, cultural e paisagistico, com a finalidade de implantar um Parque Municipal;

-Fortalecer as iniciativas ambientalistas da região de Sorocaba, através da participação da Sociedade Civil organizada e poder público na luta pela Cachoeira e rio Sorocaba;

-Contribuir para o processo de tomada de consciência por parte da população, onde o processo de implantação do Parque Municipal servirá como um instrumento para a efetivação de uma proposta de Educação Ambiental e busca conjunta de soluções envolvendo a população em geral, a comunidade estudantil e órgãos públicos ligados à questão ambiental." (Melo,1991).

Tendo em vista o objetivo também didático do Projeto, que foi lido e discutido com os demais membros do Grupo Ecológico, também foi incluída uma revisão bibliográfica sobre Educação Ambiental, Pesquisa-ação e Pesquisa-participante, Áreas Verdes Urbanas e Revegetação de Áreas Degradadas. Detalhou-se o Diagnóstico do Meio Físico (composição florística, levantamento pedológico/geológico, hidrologia,uso atual e ocupação da área) e Percepção da População. Após esse diagnóstico, seriam seguidos os princípios do Planejamento de Uniclades de Conservação (zoneamento) para 
a definição das estruturas/obras que seriam implantadas. Apresentava-se um cronograma detalhado, com previsão para início dos trabalhos em agosto de 1991 e término (implantação do Parque) em agosto de 1993, bem como um orçamento detalhado para a etapa do diagnóstico.

Assim que foi elaborado, enviou-se uma cópia do referido Projeto para a Prefeitura, pois tinha-se a esperança de que, ao explicitar as intenções e detalhá-las, tornasse possível um efetivo envolvimento visando sua execução, pois até aquele momento não existia tal nível de detalhamento claramente exposto.

Em paralelo a essa nova tentativa de implementação da proposta do Parque Municipal, durante o ano de 1991 destacaram-se as seguintes atividades do Grupo Ecológico:

-elaboração de uma minuta de Projeto de Lei de "Política Municipal de Meio Ambiente", onde propunha-se a criação de uma estrutura dentro do poder público para 0 trato das questões ambientais e os instrumentos da política ambiental municipal. Apresentado em fevereiro de 1991, somente foi aprovado em dezembro de 1992, sendo que o capítulo original onde foi proposto a criação do COMDEMA-Conselho Municipal de Defesa do Meio Ambiente foi revogado, por já existir uma Lei (no. 557, de 27/12/95) que criava tal Conselho, porém o mesmo nunca foi efetivado.

-viabilização do Evento "Passeio Ciclístico Ecologia sobre duas rodas", com intensa mobilização dos integrantes do Grupo Ecológico. O passeio foi programado para o dia 02/03/91, com ampla divulgação na cidade e grande participação e cobertura da imprensa local e regional. Com saída da sede do Grupo Ecológico (Escola Estadual "Profa. Edith Maganini") e chegada na área da Cachoeira, junto ao Campo de Futebol do "Cachoeira", o evento também contou com uma exposição dos trabalhos do Grupo Ecológico Cascata Branca, Núcleo Ecológico Morro de Ipanema, Núcleo Ecológico Represa Itupararanga, Grupo Resgate de Sorocaba (formado por crianças e adolescentes de Sorocaba que uniram-se para proteger um remanescente florestal siginificativo em área urbana, que posteriormente foi transformado em Parque Municipal), Clube de Observadores de Aves de Sorocaba, Policia Florestal e de Mananciais, Associação das 
Empreiteiras de Sorocaba (mobilizados na época em um projeto de despoluição do rio Sorocaba) e Departamento Estadual de Proteção de Recursos Naturais.

-Organização do Evento "Concurso de Desenhos, Frases e Redações sobre a Cachoeira", em conjunta com a Delegacia de Ensino de Votorantim, evento este lançado no dia do passeio ciclístico. O evento foi aberto para todas as escolas abrangidas pela Delegacia de Ensino, que abrange os municípios de porém sem Votorantim, Piedade, Tapiraí, Salto de Pirapora, com cerca de 15000 alunos. Foram selecionados 03 trabalhos por escola em cada categoria: 1a. a 4a. série (desenhos), 5a. a 8a. série (frases) e colegial (redação). Os trabalhos foram selecionador por uma comissão julgadora e a premiação se deu dentro das comemorações da Semana do Meio Ambiente.

Durante esse periodo de intensas atividades internas e de organização de eventos, intensificaram-se as cobranças junto à Prefeitura para ao menos iniciar a discussão do Projeto apresentado em março de 1991, por meio de artigos na imprensa local e regional, porém sem sucesso, havendo uma cobrança mais contundente, expressa pelos títulos das reportagens: "Cachoeira: grupo ameaça acionar a prefeitura" (Folha de Votorantim, 09/06/91) e "Ecologistas reclamam do descaso" (Cruzeiro do Sul, 21/05/91). A única manifestação emitida pelo Prefeito, contida nessa última reportagem, foi a de que "o projeto do Parque Ecológico é muito bonito, mas bastante caro. Não vamos decidir com pressa por fazê-lo ou não", argumentando ainda que a área estava em processo de desapropriação, e que também não tinha lido o projeto, que estaria sendo analisado por seus assessores.

O Grupo então prosseguiu suas atividades mais centradas na estruturação interna e desenvolvimento de projetos na escola, como a implantação tentativa da coleta seletiva e a recuperação do jardim. Nesse período, a integrante do Grupo Ecológico Laura Jane, acadêmica de Eng. Florestal, participou do 1o. Encontro Nacional de Educação Ambiental, realizado em Curitiba-PR no periodo de 29/07 a 03/08/1991, apresentando o trabalho "Atividades de Recuperação e Educação Ambiental no município de Votorantim, SP", basicamente uma síntese do histórico do grupo e seus projetos, enfatizando a falta de envolvimento do Poder Público local. 
Nesse evento, por iniciativa de seus participantes após as discussões surgidas com a apresentação do trabalho, foi elaborado um abaixo-assinado, que obteve 158 assinaturas e foi enviado para o Gabinete do Prefeito e Câmara de Vereadores. Nos "considerandos" do abaixo-assinado, elogiou-se a existência de uma área verde de 10 hectares de importância ambiental, cultural e paisagística para a cidade e a luta do grupo "Cascata Branca" em prol da implantação do Parque, pedindo à prefeitura que de imediato assumisse a execução do Projeto. Mesmo com essa pressão externa, não houve nenhuma manifestação positiva da Prefeitura em abrir a discussão sobre essa proposta de Projeto.

Integrantes do Grupo Ecológico então iniciaram um trabalho junto às escolas estaduais locais, por meio de apresentação de slides sobre problemas ambientais locais, o potencial de áreas do município para atividades de turismo e mais detalhadamente sobre o potencial da área da cachoeira, bem como sobre as atividades do Grupo Ecológico. A reportagem publicada no Jornal "Cruzeiro do Sul" no dia 21/08/91 já expressava o relacionamento com a Prefeitura na época:

" A intenção dos ecologistas é levar este trabalho à população geral, através de associações de moradores e outros segmentos, para que possa surgir uma mentalidade mais voltada à preservação. $O$ que hoje, segundo disse, não existe. $O$ fato, acrescenta $o$ engenheiro florestal Adriano Lopes, pode ser notado no comportamento da administração municipal em relação à questão. Segundo ele, as tentativas de levar até o prefeito as propostas do grupo são diretamente descartadas $\mathrm{e}$, até mesmo o projeto de construção do "Parque Municipal da Cachoeira de Votorantim"entregue ao prefeito em março deste ano - "nem foi lido pelos técnicos". Isso, diz Laura, porque muitas pessoas distorcem a intenção do grupo e associam às suas realizações pretextos políticos ou financeiros. "Nós sobrevivemos por nossa boa vontade e não temos qualquer vínculo partidário", afirma Adriano. Além disso, acrescenta, "não queremos confronto, só discutir um 
problema que é de toda a comunidade"(Cruzeiro do Sul, 21/08/91, p.03).

Esse artigo expressou o espírito de desentendimento que se estabeleceu em motivo do descaso da administração municipal em relação às propostas do Grupo.

Essa situação de uma postura crítica de integrantes do Grupo em relação à postura da Prefeitura atingiu um grau que pode ser considerado "máximo" com a publicação de uma carta nos dois jornais, um local (Folha de Votorantim,,22/09/91) e outro regional (Cruzeiro do Sul), que pela sua importância merece uma transcrição integral:

\section{"SENSIBILIDADE AMBIENTAL X DESINTERESSE}

Ao completar um ano de atividades, o Grupo Ecológico Cascata Branca prossegue sua luta. Formado em agosto de 1990 por adolescentes da E.E.P.G. "Profa. Edith Maganini", este grupo veio somar esforços a nossa iniciativa, pois como estudantes de Engenharia Florestal, sentimo-nos na obrigação de contribuir para a melhoria da qualidade de vida da nossa cidade. Como votorantinenses, muito nos preocupa o quadro de degradação ambiental, fruto de um processo de crescimento urbano-industrial feito sem critérios técnicos nem planejamento, iniciado a mais de um século.

Entre os principais problemasm encontramos: a proliferação de loteamentos na Serra de São Francisco sem sistemas de tratamentos de esgotos, que poderá compremeter definitivamente a Represa Itupararanga, que abastece várias cidades da região; o rio Sorocaba servindo como canal de esgoto (100\% do esgoto doméstico de Votorantim é nele despejado sem qualquer tratamento), a falta de áreas verdes e arborização urbana; a problemática do lixo, onde alguns moradores menos esclarecidos transformam áreas desocupadas e mesmo ruas em verdadeiros 
lixões; os morros sem vegetação protetora sujeitos à erosão e deslizamentos, bem como ausência de vegetação ao longo de rios e córregos que contribuem para o assoreamento e finalmente, a triste situação de nosso patrimônio histórico, cultural e ambiental, que deu origem ao nome de nossa cidade e do maior grupo privado nacional: VOTORANTIM, a Cascata Branca.

Frente à essa realidade catastrófica, iniciamos um movimento que visa a implantação de um Parque Municipal na área da cachoeira, contando com a participação de várias entidades ligadas direta ou indiretamente à questão ambiental, como a Secretaria do Meio Ambiente Estadual (CETESB e DEPRN), Centro de Apoio Florestal do Grupo Votorantim, Entidades Ambientalistas da região, Professores da Escola Superior de Agricultura da USP de Piracicaba, Delegacia de Ensino, Associações de Moradores e outros. Infelizmente, o órgão que deveria ser o mais interessado em apoiar e participar não demonstrou interessem apesar dos inúmeros convites, a nossa Prefeitura. Isso levou à desarticulação do movimento.

Apesar disso, continuamos a luta e elaboramos um projeto ("Implantação do Parque Municipal da Cachoeira de Votorantim com a Participação da População") com apoio de professores da USP, que foi entre em março deste ano ao Coordenador de Obras da Prefeitura, Sr. Ademir Amaral, para estudos. Até o presente momento, nada obtivemos como resposta. A "resposta" que conseguimos por parte do Executivo é o puro descaso e preconceito, com o argumento de que o Grupo Ecológico tem "fins políticos", ou seja, seremos "candidatos" nas próximas eleições. Cumpre aqui esclarecer que nosso movimento é apartidário e não estamos culpando ninguém pela atual situação, o que pretendemos é que toda a população, inclusive nossa Prefeitura, se conscientize e 
atue, pois ainda podemos reverter o quadro de degradação existente.

Acreditamos que um dos fatores que contribui para esse desinteresse, além da falta de vontade política, é a ausência de um técnico ligado à área na Prefeitura (biólogo, ecólogo...) dificultando assim a comunicação.

Entendemos também que essa mentalidade preconceituosa é fruto do processo de anos de repressão e limitação dos direitos do cidadão que o nosso país sofreu, mas esperamos que o bom-senso prevaleça e não tenhamos de esperar mais vinte anos para sermos entendidos.

Ecologia não é um modismo passageiro, é uma questão de sobrevivência para a humanidade, e a solução para nossos problemas mais graves (ambientais, sociais, econômicos, politicos) depende da participação de todos os setores da sociedade. As grandes mudanças começam a partir das pequenas, do nosso próprio comportamento, do dia-a-dia como cidadãos" (Melo \& Gomes, Folha de Votorantim, 22/09/91, p.02).

Assinaram esse manifesto o autor, já graduado em Engenharia Florestal e L.J., então estudante de Engenharia Florestal da Escola Superior de Agricultura de Lavras, Minas Gerais.

Nessa fase de indefinição em relação à viabilização da proposta de implantação do Parque, se destacaram entre as atividades externas do Grupo a participação no "2o. Encontro de Educação Ambiental para Técnicos de Zoológicos do Brasil", realizado no Parque Zoológico Municipal "Quinzinho de Barros" de Sorocaba, no período de 30/08/91 a 01/09/91, sendo apresentado em forma de painel as atividades e propostas do Grupo Ecológico "Cascata Branca".

Outra atividade de destaque foi a apresentação que integrantes do Grupo Ecológico realizaram para os vereadores do município, no dia 02/09/91. Com uma série de slides, apresentaram-se os principais problemas ambientais de Votorantim, seus 
potenciais em termos de recursos ambientais e paisagisticos e em maior detalhe a área da Cachoeira e a luta dos integrantes do Grupo para a implantação de um Parque Municipal, chamando atenção para o descaso da administração para com aquela proposta. Participaram da exposição nove dos dezessete vereadores da cidade.

Nesse periodo também o autor, representando o Grupo Ecológico, participou do VI Encontro Nacional de Organizações Não-Governamentais, realizado no Palácio das Convenções do Anhembi (27/09/91), preparatório para o Forum de ONGs paralelo a ECO-92.

Passou-se então para uma atitude de cobrança mais efetiva de um posicionamento da Prefeitura em relação à proposta de implantação do Parque através de uma série de artigos na imprensa, com destaque para o artigo supracitado ("Sensibilidade ambiental $\mathrm{X}$ desinteresse"), publicado em 22/09/91 no periódico local. Esse artigo foi precedido de um artigo bastante crítico de um vereador do PT, publicado em 12/09/91 e motivado pela apresentação dos problemas ambientais de Votorantim na ótica do Grupo, por meio de palestra ilustrada com slides, tendo como público os vereadores.

Neste período conturbado, a área foi finalmente desapropriada. Ocorreu então uma reunião no dia 19/11/91, na Prefeitura, entre os integrantes do Grupo Ecológico e técnicos da Prefeitura, onde os mesmos informaram sobre a "intenção" de ser iniciado um trabalho na área e os mesmos "apossaram-se" da idéia da criação de uma Fundação, que seria inicialmente mantida pela Prefeitura e depois buscaria-se apoio externo, "aproveitando-se" da movimentação em torno da ECO-92. Esse posicionamento finalmente trouxe alguma esperança ao Grupo de que finalmente poderia ser iniciado algo de prático na área.

Porém, contrariando as expectativas, nenhuma atitude concreta anunciada pelo Coordenador de Obras e Assessores foi posta em prática. A Prefeitura não criou a fundação nem iniciou qualquer trabalho prático em conjunto com os integrantes do Grupo Ecológico, frustrando as expectativas de seus integrantes. Chegava-se ao final do ano de 91 sem resultados práticos em relação à proposta principal do Grupo.

Uma série de fatores levou ao desestímulo e ao início da diminuição do ritmo das atividades do Grupo Ecológico no ano de 92. Entre os principais, destacamos: 
- O núcleo original do Grupo Ecológico, formado no ano anterior quando os alunos estavam na 7o. série, dispersou-se pelo fato do término do 10 . grau, uma vez que a Escola só mantinha os cursos até a 8o. série. Apesar de terem se agregado novos elementos durante o ano de 91 , já previndo-se essa saída, a dinâmica já não era a mesma em função do nivel de envolvimento ser diferenciado;

- A professora coordenadora, que estimulou a criação do Grupo e teve participação ativa e fundamental para o andamento das atividades e projetos tanto internos (na escola) quanto externos desligou-se da Escola, dedicando-se a uma Escola particular de Sorocaba no ano seguinte (92). Apesar de outros professores terem dado uma certa continuidade à coordenação do Grupo Ecológico, a dinâmica era diferente e podemos considerar também que o nivel de envolvimento não era tão intenso;

-o autor, um dos coordenadores do Grupo principalmente em relação às atividades externas, em função de motivos profissionais (início de trabalho no Escritório do DEPRN em Registro, Vale do Ribeira), não tinha mais condições de manter o mesmo nível de envolvimento e participação.

Outro fator desestimulante era o ano eleitoral (92), que trazia poucas expectativas em relação ao início de qualquer trabalho efetivo na área da Cachoeira por parte da administração, devido a quebra de continuidade das ações da Prefeitura.

Apesar desses fatores, o Grupo continuou reunindo-se semanalmente, porém com poucas atividades mais elaboradas e de repercussão fora da escola. Foram desenvolvidas atividades do coleta seletiva do lixo da escola, a implantação de uma Horta para uso na merenda escolar, a implantação de um viveiro de plantas medicinais e ornamentais entre outras atividades.

Destaca-se durante o ano de 92, a realização de uma excursão de integrantes do Grupo Ecológico para Ilhabela, um "prêmio" oferecido pela Delegacia de Ensino local como reconhecimento pela importância do trabalho que vinha sendo realizado pelo Grupo e a participação de integrantes do Grupo na organização de um Encontro entre os Candidatos à Prefeitura Municipal, realizado no salão paroquial da Igreja Matriz da Cidade. 
Esse evento teve grande participação da população, com a discussão de temas gerais por parte dos candidatos que compareceram, entre os quais inclui-se na pauta assuntos relativos a questão ambiental. Foi o primeiro debate entre os candidatos feito na cidade, que inclusive não mais se repetiu após a desestruturação do Grupo (final de 93).

Estava programado, nesse Encontro, a apresentação de um histórico do Grupo Ecológico e suas propostas, porém em função do aprofundamento nos temais mais gerais, por uma questão de tempo disponível, essa apresentação não foi feita. Foi elaborada uma pauta de "Propostas Básicas do Grupo Ecológico Cascata Branca para a Administração Municipal para a Área de Meio Ambiente - Gestão 1993/1997", pedindo-se o compromisso dos participantes em assumí-las por escrito, no final daquele encontro. Todos os participantes assinaram um "Termo de Compromisso" de forma a analisá-las e implementá-las, menos um dos candidatos, Erinaldo Alves da Silva, que já havia sido Prefeito em duas gestões anteriores e vice-prefeito na segunda administração de Votorantim após a emancipação. Erinaldo venceu a eleição municipal, em coligação liderada pelo PSDB.

As propostas apresentadas por escrito aos candidatos foram as seguintes:

"1. Estabelecimento de uma Política Municipal de Meio Ambiente, conforme estabelece a Lei Orgânica Municipal, incluída a implantação imediata do COMDEMA-Conselho Municipal de Defesa do Meio Ambiente;

2. A criação de uma Secretaria Municipal de Meio Ambiente na estrutura da Administração Municipal, responsável pela aplicação da Política Municipal de Meio Ambiente e com corpo técnico adequado e capacitado.

3. Implantação de um Programa de Coleta Seletiva e Reciclagem de Lixo Urbano, com participação da comunidade.

4. Implantação do Parque Municipal da Cachoeira em parceria com - GECBEM e outras entidades, baseando-se em proposta já existente. 
5. Viabilização do Tratamento dos Esgotos domésticos através da implantação de estações de tratamento, uma vez que hoje todo o esgoto vai para o rio Sorocaba e outros sem qualquer tratamento. 6. Participação efetiva do Poder Público no Consórcio de Municípios para a despoluição e desenvolvimento da bacia do rio Sorocaba e Represa Itupararanga.

7. Realização de estudos, com apoio de outras entidades, visando a utilização turístico-educativa das áreas do município hoje inacessíveis, como a Represa da Prainha e Serra de São Francisco.

8. Realização de estudos, com apoio de outras entidades, visando a implantação de áreas de proteção ambiental ou de relevante interesse ecológico dentro do município.

9. Reestruturação da Biblioteca Municipal e Museu, com aquisição de novas bibliografias e a sistematização de todo o acervo histórico do município (quadros, artigos de jornal, peças, livros), visando resgatar nossa rica história de pioneirismo industrial e esportivo.

10. Criação e manutenção de áreas verdes urbanas, buscando atuar junto de associações de moradores e outras entidades no sentido de dividir as tarefas e responsabilidades" (Grupo Ecológico Cascata Branca, 1992)

Finda-se o ano de 92 com o Grupo Ecológico em rápido processo de desestruturação, frente ao quadro anteriormente exposto e a falta de um projeto prático mais amplo e motivador.

Inicia-se o ano de 93, com o Grupo ainda mantendo-se com reuniões semanais porém com menor participação e falta de um projeto aglutinador maior que motivasse os alunos e envolvesse o ambiente extra-escolar. Novas saidas de integrantes que completaram o primeiro grau no final do ano anterior contribuiram para a continuidade dessa situação.

As referências existentes da atuação do Grupo naquela época restringem-se a continuidade, em menor ritmo, do projeto de coleta seletiva na escola (com sérios 
problemas de armazenamento e venda do material, que acabou por inviabilizar a proposta), a manutenção da Horta e viveiro de plantas medicinais/ornamentais e a realização de um concurso interno para a escolha do desenho e frase para uma nova camiseta do Grupo Ecológico.

$\mathrm{O}$ único evento mais amplo, com cobertura da imprensa local, foi a iniciativa dos integrantes do Grupo de montar uma barraca na festa junina da escola que trocava material reciclável por salgadinhos e refrigerantes, após um trabalho de panfletagem e mobilização dos moradores do bairro. O contato com a adminstração restringiu-se a uma ida de integrantes do Grupo ao Gabinete do Prefeito, no início do ano, para solicitar terra adequada para a reforma ds jardins e horta.

Nesse ano, o autor ingressa na carreira de pesquisador científico do Instituto de Botânica, na área de Educação Ambiental, desenvolvendo suas atividades no Jardim Botânico da Capital (Secretaria de Estado de Meio Ambiente). Nessa época (janeiro a setembro de 1993), o autor tentou um novo contato com a nova equipe da adminitração, realizando cerca de 02 reuniões com o Secretário de Obras (maio/93) visando a implantação de um Termo de Cooperação Técnica entre a Prefeitura e o Instituto de Botânica.

Foi apresentado em junho de 1993 um "Plano de Trabalho- Principios Básicos", com uma clara exposição do envolvimento do autor com a questão ambiental local e com o Grupo Ecológico Cascata Branca, bem como os princípios que deveriam nortear a proposta, entre os quais destacamos:

"4. O projeto de implantação do Parque da Cachoeira não é um fim em si mesmo, ou seja: o processo de implantação é o mais importante, no qual a participação da comunidade será incentivada e elemento essencial para o sucesso da proposta. Todos os conhecimentos técnico-científicos serão colocados como meios para atingirmos os objetivos estabelecidos"(Melo, 1993, p. 03).

Foi anexado no Plano de Trabalho uma minuta de Termo de Cooperação Técnica entre a Prefeitura e o Instituto de Botânica, para análise e encaminhamentos. 
Em paralelo a essa nova tentativa de resgatar as propostas do Grupo Ecológico, agora no papel de um pesquisador de uma instituição pública, houve também a tentativa de reestruturar o Grupo Ecológico através da elaboração de um "Programa de Capacitação" para os integrantes do mesmo, elaborado em maio/junho de 1993 pelo autor. Esse programa tinha como objetivos, através de metologias participativas, discutir temas de interesse (Lixo, Importância dos Recursos Naturais, Participação) e contribuir para a efetiva organização do Grupo Ecológico. Devido as dificuldades de organização e ao próprio processo de desestruturação do Grupo, que na época tinha poucos abnegados participantes, bem como do fato do autor estar trabalhando em São Paulo, não permitiram a realização desse Programa.

Pode se considerar esse momento como a fase terminal do Grupo Ecológico, tendo em vista que o mesmo desestruturou-se totalmente no segundo semestre de 1993, momento este que "coincidiu" com uma nova fase a ser estudada: o ingresso do autor no quadro de servidores municipais, através de convite direto do Prefeito Municipal na época (setembro/1993).

Essa reconstituição da trajetória do Grupo Ecológico foi feita pelo autor incluiu as suas percepções pessoais enquanto protagonista desse processo, fruto de um envolvimento intenso e histórico com a questão.

\subsection{Depoimentos de ex-integrantes}

Foram feitas uma série de entrevistas (cerca de 08) com ex-integrantes e pessoas que colaboraram direta ou indiretamente com as atividades do Grupo.

Optou-se por não seguir um roteiro rigidamente estabelecido, em função da possibilidade de aprofundamento de temas que porventura não estivessem préestabelecidos, porém procurou-se abordar questões principais, dentre as quais citamos:

1. O envolvimento com a questão ambiental - origens, motivações

2. Como se deu o surgimento do Grupo Ecológico Cascata Branca

3. Atividades desenvolvidas pelo Grupo que foram mais marcantes 
4. O papel do Poder Público, das entidades organizadas e dos cidadãos na questão ambiental.

5. Relevância da participação no Grupo Ecológico

Passaremos então a analisar o conteúdo dessas entrevistas, com base nos temas principais abordados. Cabe ressaltar que já existiam diferentes graus de envolvimento com a questão ambiental antes do início das atividades do Grupo Ecológico. Os entrevistados foram:

-L.J., na época estudante de Engenharia Florestal da Escola Superior de Agricultura de Lavras, M.G. Moradora da cidade, entre os anos de 84/86 mobilizou-se para a implantação de uma área verde próxima a sua residência, composta de um remanescente florestal com uma nascente em área de encostas conhecida como "área do Matão". Juntamente com uma prima na época, criou um grupo denominado "Fundo de Quintal Verde" e mobilizou a comunidade local através de passeatas e panfletos distribuídos pelas crianças para que não fosse jogado lixo doméstico naquela área, bem como contatou a administração municipal na época para que fosse viabilizada a implantação do Parque. Participou também da Associação de Moradores do Bairro e acompanhou o processo de transformação da área do "Matão" em um Parque, cedido por comodato para um particular explorar com mini-zoológico por um período de 10 anos. Trata-se do único Parque implantado no município, que embora sendo de acesso não livre (cobrado ingresso), desenvolve atividades de sensibilização e educação ambiental, contando com técnicos e infra-estrutura para tal.

- M, professora da Escola que incentivou a criação do Grupo Ecológico e o coordenou no seu período de maior atividade, atualmente trabalha na Oficina Pedagógica da Delegacia de Ensino de Votorantim;

-A.M, integrante do Grupo desde a sua formação, um dos membros mais ativos, contonuou participando em menor intensidade mesmo após o término do lo. na Escola. Atualmente está terminando a graduação em Engenharia Florestal na ESALQ/USP;

- G., também integrante do Grupo na sua fase mais intensa e desde sua formação, formado em magistério; 
- M.P., aluno da Escola, iniciou sua participação no Grupo já na fase de atividades menos intensas (92/93);

-A, teve grande participação como colaborador do Grupo no período de sua maior atividade. $\mathrm{Na}$ época (91), representava a entidade NERI (Núcleo Ecológico Represa Itupararanga) e era membro da Diretoria do Sindicato dos Têxteis de Sorocaba e Votorantim, frequentemente colocando a infra-estrutura do Sindicato para as atividades do Grupo (gráfica, veículo). Em 91, envolveu-se com a problemática dos sem-teto em Votorantim, organizando ocupações e criando uma Associação dos Sem-Teto, que com sua pressão conseguiu a desapropriação de uma área do Grupo Votorantim com cerca de 10 hectares para a implantação de um loteamento popular em um bairro da periferia. Elegeu-se vereador pelo PT para a legislatura 93/96. Nos primeiros meses de legislatura, por motivo de divergências com a bancada do PT para a eleição da presidência da Câmara, desfiliou-se e passou para a bancada de sustentação do Prefeito (PSDB). Frente a problemas de divergências na condução da política habitacional por parte da administração, passou para a oposição, ficando sem partido, depois filiando-se no PDT e depois no PMDB. Passou então a efetuar intensa oposição e pressão junto à Prefeitura, com passeatas e "abraços" dos sem-teto no Gabinete do Prefeito em relação ao problema dos sem-teto. Não conseguiu reeleger-se e desapareceu da cena política após 1996, mudando-se de Votorantim.

- L, Diretor da Escola na época do Grupo Ecológico, cujo filho também participou da Entidade no período de maior atividade.

Envolvimento com a questão ambiental

Em alguns integrantes/colaboradores, a preocupação com a questão ambiental já estava presente há muito tempo. Para L.J.

"meu envolvimento com a questão ambiental está arraigado, acho que desde que eu nasci". Já A tem uma explicação interessante: "...parece que a gente já nasceu com esse "vírus", o virus da preservação, da consciência, e muito antes de vir morar em 
Votorantim, a gente ouvia falar nos movimentos em prol da despoluição do rio Sorocaba..."

M, por sua vez, nos dá um depoimento singelo:

“"Eu tenho uma história de vida muito simples. Eu nasci num sítio, fui criada numa fazenda, eu gostava e hoje ainda gosto muito da natureza, que é um negócio muito sério. Quando eu fui obrigada a vir embora para a cidade, acho que eu já nasci professora. Eu tenho certeza que eu "nasci" professora." “

$\mathrm{G}$, por sua vez, coloca o início de seu envolvimento com a questão ambiental com o processo desencadeado pela professora M na Escola, assim como A.M. e MP, ou seja, o despertar para o interesse da questão ambiental foi propiciado pelas propostas colocadas em prática da professora $\mathrm{M}$. .

Observamos então que existem claramente dois niveis de envolvimento, sendo um anterior ao início das atividades do Grupo, manifestado pelas pessoas que coordenaram e colaboraram com os trabalhos (L.J., M, A) e os alunos que iniciaram a participação no Grupo. No caso, L demonstrava já ter um "histórico" de intervenção e cobrança das autoridades em relação a problemas ambientais locais, senão vejamos:

"Que eu me lembre, aqui em Votorantim o envolvimento que eu tive, que eu iniciei a exercitar a vontade de cuidar melhor do ambiente que a gente vive foi com a questão do "Matão". O "Matão" é uma área verde próxima da minha casa $(. .$.$) e eu$ observava que o pessoal da Prefeitura limpava a área, colocava fogo e destruía o sub-bosque (...) eu me lembro que fiz um abaixoassinado (...) na época consegui mais de 100 assinaturas das pessoas que moram no entorno da área (...) que a área do Matão fosse um Parque, fosse uma área de lazer para os moradores. Então ele (o Prefeito) me recebeu na época, só que ele falou para mim que a área do Matão não era prioridade para a gestão dele. Aí foi o que bastou, eu sai de lá, entrei em contato com os jornalistas de Sorocaba, com um jornalista que nem lembro o nome, envolvido 
com a questão ambiental, que me atendeu e nós fizemos uma reportagem que saiu no jornal, que o Prefeito não dava confiança para as áreas verdes da cidade, para a formação de parques, que não era prioridade para ele, e ele respondeu até, ele ficou muito bravo, na época ele falou que eu estava muito mal informada, que o Matão era prioridade para ele sim, que sairia, mas não era para agora, era para longo prazo".

Esse depoimento já demonstrava um histórico negativo da relação do poder público local com movimento organizado em prol da implantação de uma área verde. Tal Parque não foi implantado naquela gestão.

Já A, na época da atuação junto ao Sindicato dos Trabalhadores das Indústrias Têxteis, cita a pressão exercida junto às indústrias para a implantação de sistemas de tratamento de efluentes:

" A legislação, através das questões de meio ambiente, obrigava as indústrias a tratar dos resíduos, dos resíduos industriais, então Sorocaba, na área das empresas têxteis, principalmente as indústrias têxteis que tinham uma contribuição muito grande, a gente coseguiu, até 1989, que praticamente todas as empresas tivessem construído seu sistema de tratamento de resíduos."

Esse trabalho se confundia com a entidade por ele criada, o NERI-Núcleo Ecológico Represa Itupararanga. Na realidade, tal "entidade", segundo informações do mesmo, tinha apenas mais poucos integrantes em Piedade e Ibiúna, sendo um meio "oficial" de exposição de idéias e cobrança de atitudes de fiscalização principalmente, junto aos órgãos de controle da poluição e curadoria do meio ambiente, consistindo do "braço ecológico" da atuação sindicalista/ambientalista de A. O NERI lançou panfletos educativos a respeito de problemas que ameaçavam a represa Itupararanga, manancial que abastece vários municípios da região e onde se concentram também significativos remanescentes florestais, sendo que atualmente está sendo estudada a regulamentação da Área de Proteção Ambiental da Represa Itupararanga dentro de iniciativa da Secretaria de Estado de Meio Ambiente. 
Surgimento do Grupo Ecológico

Em relação ao surgimento do Grupo Ecológico, reforça-se a confluência positiva de interesses. L.J., lembra-se que foi procurada no início de 1990 pelo autor para tentar fazer alguma coisa em relação à área da cachoeira:

"Quando o Adriano me procurou, como eu estive envolvida com a questão do Matão, sempre preocupada com a questão ambiental, e na época já fazendo Engenharia Florestal, não tinha esse lado afetivo com a área da cachoeira do jeito que o Adriano tem, mas na hora eu aceitei, achei ótima a idéia, a gente tinha que idealizar, levar em frente, na hora que ele me falou comecei a imaginar um Parque formado, pessoas visitando e tudo em harmonia naquela área, a área é realmente muito bonita".

As reportagens da "Folha de Votorantim" motivaram os alunos da Escola Estadual "Edith Maganini", como citou L:

“... em função das aparições nossas no jornal, da nossa intenção de fazer um Parque na área da cachoeira, um grupo de alunos de uma escola pública, de uma escola estadual, sexta série, as crianças se mobilizaram ao lerem a reportagem, e resolveram formar o Grupo Ecológico. Fiquei surpresa, muito feliz, poi percebemos que a nossa luta, que a gente não estava sozinho".

Outra integrante do Grupo, M., professora da escola, assim relatou o surgimento do Grupo:

"Quando eu me vi dentro de uma escola, até hoje eu comentava com as professoras daqui, eu tinha um sonho muito grande, achava que eu poderia mudar o mundo. De repente, a gente percebe que as coisas são muito complicadas. Mas mesmo assim, quando comecei a trabalhar na "Edith", eu percebi aquelas crianças com uma necessidade muito grande de fazer alguma coisa a mais além do que 
estava na escola. Essas crianças não tinham lazer, nada. Então, eu comecei a procurar alguma coisa nova, para envolver essas crianças e evitar que ficassem na rua. Quando eu li aquela reportagem que saiu no jornal, que era sua e da Laura, preocupados, parecia que a preocupação era a mesma. Eram duas pessoas que eu não sabiam quem eram, aí a gente começou a procurar que era o Adriano e a Laura. Foram crianças mesmo que apareceram com essa reportagem. $\mathrm{Na}$ época, eu fazia um recorte de jornal com os problemas que aconteciam aqui na própria cidade. Até eu tinha distribuído de um trabalho numa classe, que era fantástica, a $6^{\circ}$ série, um grupo para que fosse até a Prefeitura, o que eles estavam fazendo para melhorar a qualidade de vida das pessoas que moravam em Votorantim. Começou a dar problema, comecei a receber telefonemas da escola, dizendo que as crianças não tinham perguntas bem formuladas, porque eles não queriam responder essas perguntas, é lógico. (...) $\mathrm{E}$ ai, nessa mesma semana que eles estavam fazendo esse tipo de trabalho, saiu a reportagem da cachoeira, saiu o nome do Adriano, da Laura, e as crianças começaram a procurar por vocês e acabaram encontrando. $\mathrm{E}$ aí, começou a nascer, pelo menos a gente acreditava na época, que era uma luz no fim do túnel, a gente devia agrupar as pessoas que pensavam e tinham algum ponto em comum, para tentar melhorar um pouco a situação da cidade".

O ex-integrante G. também coloca o surgimento do Grupo Ecológico da iniciativa da professora $\mathrm{M}$.:

"O Grupo Ecológico surgiu de uma forma espontânea, porque eu não te conhecia até então, de nossa professora (....) Ela preparou alguns alunos para fazer uma entrevista com os principais Secretários do nosso município, Votorantim, o Secretário de Educação, o Secretário de Esportes e Turismo (...) a proposta inicial era saber o que eles estavam fazendo em relação ao nosso 
município que até então estava assim completamente abandonado nessas duas pastas da administração. (...) As perguntas eram simples mas bastante elaboradas, perguntas assim que de repente falavam de assuntos políticos da cidade. Um dos temas abordados foi o Centro Esportivo do nosso Bairro que estava desde 77 até 90 , já eram 13 anos de abandono, nós fomos também cobrar esse não pequeno, mas grande descaso com a comunidade".

O mesmo cita as iniciativas do Grupo na própria escola, como a recuperação do jardim e campanhas de limpeza, até que aquele artigo publicado na Folha de Votorantim motivou-os para um trabalho mais abrangente.

Esse mesmo envolvimento através da iniciativa da professora também foi citado por A. M. :

"Nós fizemos uma série de questões, sobre inclusive áreas verdes, sobre a atuação do Secretário de Cultura e a possibilidade de criação de novas atividades e perguntamos se tinha mais algum grupo envolvido e ele disse que não, e propomos então a criação de um Grupo Ecológico, que na época não tinha um nome definido. Voltamos para a sala de aula, todos os alunos entusiasmadíssimos para discutir, e surgiu a possibilidade de estamos montando esse Grupo Ecológico, aob orientação da Professora. Tempos depois nós voltamos a nos reunir para estar colocando nome no Grupo, e surgiram vários nomes, desde "Amigos da Onça" até "Cascata Branca". Depois de algum tempo, descobrimos que tinham mais dois alunos, que na época eram estudantes de Engenharia Florestal e cujas questões eram semelhantes. Foi marcado depois disso uma reunião, e os objetivos se encontraram e a partir de então começamos a trabalhar no mesmo rumo."

No caso de M. P., aluno da escola, sua participação se deu quando o Grupo já se encontrava em atividade, em 92 . Já A ., na época sindicalista e integrante de entidade 
NERI - Núcleo Ecológico Represa Itupararanga, após citar seu envolvimento com a questão ambiental coloca:

"Quando a gente veio para Votorantim, a gente através da imprensa, começou a observar o trabalho de um grupo de uma escola que havia feito algumas publicações, algumas manifestações nesse sentido, um grupo denominado GECBEM - Grupo Ecológico Cascata Branca da Escola "Edith Maganini"(...) e a gente procurou essas pessoas, que na época estavam envolvidas nesse trabalho para a gente estar se unindo, unindo as forças no sentido de estar lutando pelo mesmo objetivo."

O então Diretor da Escola, L. , assim sintetizou o surgimento do Grupo:

"Foi mais ou menos nesse periodo, agosto de 90, a gente estava até pensando em fazer um mutirão de limpeza na Escola, aí junto com os alunos, conversando com eles, e eles acharam bom, e então depois de feito o mutirão surgiu então a idéia de formar esse Grupo, para trabalhar alguma questão relacionada com a Escola,com o meio ambiente."

Atividades realizadas pelo Grupo

Nos vários depoimentos colhidos, as atividades mais marcantes em geral foram aquelas ligadas à organização de eventos de repercussão na cidade, como o Passeio Ciclístico e outros. L.J. cita:

" o mais interessante nesse grupo é que eles se mobilizaram, os movimentos que surgiram a nível municipal, das crianças quererem promover o passeio ciclistico "Ecologia sobre duas rodas", que de uma maneira ou de outra envolveu a Prefeitura, Associação Comercial (...) aquele Concurso de Frases e Redação sobre a Cachoeira, o primeiro concurso que foi intessante por envolver toda a rede de ensino do município, a própria elaboração do projeto com 
a participação do Grupo Ecológico (...) aqueles slides, mostrando através de fotografias e slides como é Votorantim, Educação Ambiental pela fotografia, mostrando os locais onde os pessoas passam todos os dias mas não percebem a dimensão do problema ambiental, tipo lixão ao lado das escolas, assoremanento, erosão em morros (...) Naquela época, eles fizeram um treinamento, um curso no "Quinzinho de Barros" (Zoológico Municipal de Sorocaba), (...) tinha a preocupação com o Grupo se estruturar para poder atuar. L. destaca sua participação como única representante do Grupo Ecológico no $1^{\circ}$ Encontro de Educação Ambiental de Curitiba: "Aquilo foi ótimo para mim porque eu não tinha experiência em falar e apresentar trabalho em Congresso, foi minha estréia (...) O interessante é que depois da apresentaçãom eu tive contato com pessoas de outros grupos, teve o Grupo lá das nascentes do Tietê, o GENTE (Grupo Ecológico Nascentes do Tietê), tinha lá um rapaz muito...como ele falava? Que era anarquista, e eles na hora, depois da minha apresentação, resolveram fazer uma carta, uma moção de apoio ao nosso trabalho (...) eu achei interessante que foi uma iniciativa da platéia fazer essa carta, um abaixo-assinado, e enviaram para a Prefeitura de Votorantim, pedindo apoio, que a Prefeitura apoiasse nosso trabalho (...) Depois dessa carta, eu achei que fosse abrir as portas da Prefeitura, foi veiculado a nivel de jornal, a nossa ida até lá, a preocupação de outros grupos até a nível nacional, de terem reconhecido nosso trabalho, e a Prefeitura não ter reconhecido, foi um meio de dar um "puxão d orelha" na Prefeitura, mas a nivel prático não mudou nada, o Prefeito continuou irredutível às nossas investidas".

Já M., professora coordenadora do Grupo, destacou o Curso feito pelo Grupo no "Quinzinho de Barros", com apoio da Prefeitura (lanche e trainsporte), o passeio ciclístico de março de 91 e paralelo a isso cita que: 
““abertura na Prefeitura a gente tinha, o que não tinha era a efetivação de coisa mais séria, a idéia de trabalhar o Projeto da Cachoeira, tinha todo o pessoal necessário para "detonar" o Projeto, mas o Projeto não caminhava"'

M. citou também a série de reuniões ocorridas em 91 na Prefeitura com vários órgãos e que não tiveram continuidade por falta de envolvimento da Prefeitura. Destacou tanmbém o trabalho de coleta seletiva de lixo na escola, o concurso de frases, desenhos e redações sobre a Cachoeira, a horta e viveiro de mudas da escola. $M$. citou também sua participação no debate entre candidatos a Prefeito ocorrido em setembro de 92 e o fato de então o candidato Erinaldo, que foi eleito, ter se recusado a assinar um compromisso de reivindicações ligadas à questão ambiental, colocando:

“ eu participei, inclusive eu ajudei a elaborar as perguntas (...) e aí deu para perceber que a gente não ia ter, pelo menos nessa gestão, não haveria comprometimento do Prefeito, que na época era candidato ainda, quando a gente fez a colocação para o Erinaldo, ficou que ele assinasse um documento que as crianças tinham elaborado, que ele se comprometeria a desenvover um trabalho de Educação Ambiental, e ele se recusou a assinar. A partir daí esmoreceu mais ainda, se ele que viria a ganhar a eleição e ficar por quatro anos na Prefeitura já estava deixando de assinar esse documento, qual a esperança de nossas crianças que estavam lutando por uma cidade melhor? Durante quatro anos a gente tinha que nada iria ocorrer. $\mathrm{E}$ acho que a gente pode dizer que nada ocorreu mesmo".

Outro ex-integrante, G., também destacou o passeio ciclístico como o maior evento realizado pelo Grupo, bem como a apresentação de slides na Escola "Daniel Verano" e o projeto de coleta seletiva de lixo. Recordou também o Debate entre os candidatos de setembro de 92 , onde mesmo já não estudando mais na escola estadual "Edith Maganini" participou na elaboração das questões. O mesmo destacou a exintegrante A . M. , fundadora do Grupo assim como G. 
Participante da fase final do Grupo (92/93), M.P. destacou como principais eventos a implantação da horta na escola e a participação do Grupo em uma barraca da festa junina de 93 onde fazia-se a troca de material reciclável por doces e refrigerantes, com uma reportagem na periódico local. Destacou também um concurso interno para a escolha de uma nova camiseta para o Grupo Ecológico, assim como um a frase e desenho.

L., diretor da escola na época, destacou também o passeio ciclístico, o concurso de frases, desenhos e redações sobre a Cachoeira, a barraca de troca de materiais recicláveis na festa junina de 93 e o curso no Zoológico Municipal de Sorocaba. Um fato relevante é que o trabalho do Grupo chamou a atenção da Delegacia de Ensino local:

"Olha, a partir do momento que foi montado esse Grupo Ecológico, os alunos passaram a ter uma visão diferente, e através do trabalho que eles vinham desenvolvendo, o Grupo trouxe muitos beneficios para a Escola (...) Podiamos notar a seriedade com que eles participavam das reuniões, e só para ter uma idéia, à partir do momento que o Grupo começou a se firmar, houve o interesse da Delegacia de Ensino para ajudar os alunos a fazer essa pesquisa, repassou para a escola uma TV e também um vídeo, e então todos os trabalhos que faziam depois passavam aos demais, para todos tomarem conhecimento. E nós notamos que passaram a valorizar mais a Escola, e muitos deles já saíram da Escola e dá para pensar que saíram com uma "cabeça pensante".

Naquele momento então a Escola foi uma referência de trabalho de Educação Ambiental junto à Delegacia de Ensino local, tendo conseqüências positivas inclusive na destinação de recursos para a melhoria das condições de ensino da unidade escolar.

O papel dos cidadãos, do poder público e das entidades ambientalistas na questão ambiental 
A opinião dos ex-integrantes e colaboradores do Grupo Ecológico segue uma clara tendência de conflito de visões e crítica quanto à atuação do Poder Público local e em relação a questão ambiental, em função das dificuldades encontradas no desenvolvimento das atividades do Grupo. L.J., que muito antes de se envolver com o Grupo Ecológico já participara de mobilizações em prol da implantação de uma área verde no seu bairro com críticas ao Poder Público, colocou:

"enquanto alguns cidadãos eu sinto que evoluíram, em relação ao Grupo Ecológico algumas pessoas ainda perguntam sobre a existência da entidade, a Prefeitura parece que continua uma batalha, as entidades civis de um lado e o Poder Público de outro, não quer trabalhar junto, não sei porque, eles resistem a isso. Não querem trabalhar junto. Eu acho que não deveria ser dessa forma, é uma fatia que eles poderiam até usar politicamente, já que tudo eles gostam de fazer marketing (...) Poderia ter cidadãos conscientes do lado deles, contribuindo para a gestão municipal mais de acordo com as necessidades do cidadão, e eles não querem, querem continuar trabalhando sozinhos. Continua aquela visão paternalista, aquela coisa que ele te dá aquilo que quiser na hora que quiser, não quer que a população participe, reivindique, ir nas raízes das necessidades da população. Fica muito superficial"

Abordando esse assunto, M. coloca sua visão da administração a partir de um contato com o Prefeito da época, "Zeca Padeiro", quando o mesmo foi à escola atender o pedido de uma classe de ser paraninfo:

"eu o achava uma pessoa muito simples, uma pessoa boa, então na época do Grupo Ecológico não mudou minha opinião a respeito dele, sinceramente eu acho que era uma pessoa que inspirava muita confiança na gente, mas dava a impressão que não estava sabendo o que a gente queria, então ele abria espaço, fazia reunião e tal, mas dava a impressão é que ele achava que a gente não tinha muita responsabilidade, que a gente tava querendo lá era matar tempo, 
conversava com a gente e as pessoas nos enrolavam, era assim que eu via (...)".

Já $\mathrm{G}$. fez uma crítica contundente em relação à forma de atuação do poder público local:

"De 90 até 97 eu presenciei um extremo descaso mesmo né, um descaso completo das nossas autoridades, elas não vêem a questão ambiental como um assunto completamente dentro das questões administrativas da cidade, estão preocupados em fazer obras faraônicas, nossa cidade de um ano para cá está cheia de obras faraônicas, quem vê a cidade não vê que no íntimo ela está abandonada. Ela não tem uma atividade turística, ela não tem um programa que possa dar prioridade para a ecologia, a melhoria dos bairros (...)".

M.P. destacou os problemas ambientais da cidade e a importância do Grupo Ecológico e a necessidade de apoio da Prefeitura:

"O principal problema é a poluição, jogam lixo em vários rios e poluem, a chuva vem e entope os bueiros, o Grupo Ecológico se tiver apoio da Prefeitura ajuda muito, as pessoas se reúnem e ajudam, limpam (...)".

L., comentando as dificuldades encontradas pelo Grupo no encaminhamento da proposta do Parque da Cachoeira, colocou que:

"o pessoal do Grupo Ecológico, eles já sabiam o que queriam, então eles iam procurar as pessoas que poderiam dar respaldo àquilo que eles pretendiam desenvolver em nível de município. $\mathrm{E}$ quando se reuniam com o Prefeito, com pessoas também interessadas, a gente notava que eles não davam muito crédito ao Grupo, eles acham que essa idéia não iria surtir efeito, e então o que a gente vem a lamentar é que essas pessoas deixaram de acreditar no Grupo e eles então não puderam fazer o trabalho em relação ao Parque da Cachoeira". 
O ex-vereador e ex-colaborador do Grupo, A ., em seu depoimento que serviu também como um "desabafo" após não ter conseguido a reeleição e ter abandonado a cidade, assim sintetizou sua opinião:

"E a gente começou a trabalhar, começou a procurar os poderes, $\mathrm{o}$ Legislativo, o Executivo e o Judiciário, começamos também a fazer alguns movimentos (...) e quando a gente procurou o executivo, a gente acabou tendo assim uma decepção, porque para eles não era prioridade, a questão da despoluição do rio, para eles as prioridades eram outras, não havia a consciência ecológica. Teve a participação inclusive do Grupo Votorantim, colocou uma pessoa, um técnico à disposição do Grupo, que tinha participado de todas as reuniões, dentro da Prefeitura Municipal, junto aos representantes do Senhor Prefeito, que por sua vez nunca deu condições para que fosse dado continuidade ao trabalho. O que a gente queria era ações da Prefeitura no que lhe cabia, no sentido de realmente ir de encontro a uma reivindicação não do Grupo, não daquelas pessoas que estavam ali, mas da cidade de Votorantim, da população de Votorantim (...) e a gente se sentiu enrolado, eu mesmo fiquei decepcionado com esse poder, o poder executivo. $\mathrm{O}$ poder legislativo então nem se fala porque havia um atrelamento total com relação ao poder executivo, e nunca houve assim uma proposta de trabalho em relação ao poder legislativo na questão do meio ambiente."

A ex-integrande A . M. comentou com brevidade e muita propriedade sua forma de visão sobre as dificuldades que o Grupo encontrou em relação ao poder público:

"As atividades desenvolvidas pelo Grupo então foram vinculadas à luta pela despoluição da Cachoeira da Chave, que incluia um plano de implantação de um Parque para a recuperação da área, foi feito também pelos estudantes com apoio de professores da ESALQ, e depois algumas reuniões com a Prefeitura foram feitas, a 
mídia foi alarmada sobre a situação, a Prefeitura ficou um pouco assustada, que nunca tinha visto um caso como esse, de um monte de alunos lutando por um monte de coisas, e eles não tinham condições de estar amparando tudo isso, por ser uma cidade pequena e geralmente estão preocupados com afazeres e uma série de coisas que não incluem a questão ambiental".

Percebia-se então a desproporcionalidade entre o nível de envolvimento e aprofundamento da questão ambiental local por parte dos integrantes do Grupo e a administração. Enquanto reivindicações como material de consumo de escritório para as atividades do Grupo, sede provisória, apoio material e logístico para a realização de eventos como o passeio ciclístico eram atendidas pela Prefeitura, por outro lado as propostas mais elaboradas como a de implantação do Parque na área da cachoeira não tinham andamento. As possiveis causas desse comportamento serão analisadas mais profundamente em outro capítulo.

Em relação à importância e relevância da participação de pessoas em entidades ambientalistas e especificamente em relação ao Grupo Ecológico Cascata Branca, existiu um reconhecimento geral dessa importância, apesar das limitações e dificuldades encontradas. L.J. assim colocou essa questão:

“"'Acho de extrema importância a formação dessas entidades ambientalistas e a participação da população, e principalmente a participação dos estudantes que foi o nosso caso, do Grupo Ecológico, você vê o estudante evoluir, sair daquela teoria, de ver as coisas em partes, e depois através da entidade, através da ação, e a entidade proporciona essa ação, faz com que as pessoas possam na prática do dia-a-dia delas transformar o ambiente em que vivem, e aquela coisa que já está embutida na questão da educação ambiental, "agir local, pensar global", essas entidades proporcionam isso (..."'"' 
O mesmo lema do movimento ambientalista foi citado por A .M., quando perguntado sobre sua opinião do papel a ser desempenhado por essas pequenas entidades ambientalistas:

“"Pelo pouco que eu percebi, pela vivência que eu tive nesse meio, creio que aquela questão aliás muito conhecida de "Pensar global e agir local" geralmente é o lema desses grupos, que tem geralmente trabalhos pequenos mas que dentro de sua realidade conseguem gerar alguma modificação, seja pela mudança de comportamento como dissemos anteriormente de alguns componentes, ou seja pela criação de um evento na escola ou no bairro, eles tem sim toda a iniciativa, que tem uma estratégia participativa, mesmo que seja a longo prazo, e geralmente é em se tratando de Educação, eles exercem sim uma importância dentro de sua realidade, só que no contexto geral isso se torna menos conhecido, não menos importante. Mas são interessantes sim que existam e que sejam apoiados por entidades maiores. Grupos Ecológicos são assim uma estratégia definida, só que precisam ser mais estruturados para estar viabilizando tudo isso."”

M.P. nos deu um depoimento muito singelo e significativo acerca da importância do Grupo Ecológica para sua própria formação:

“'Para mim, o Grupo Ecológico trouxe muita coisa, porque em 92 essa palavra, "Ecologia", eu nem sabia direito, a palavra "meio ambiente" para mim não era nada, comentavam e eu nem me tocava. E aí quando eu entrei, comecei a participar das reuniões, eu aprendi muita coisa. Eu saía com os colegas para bagunçar, quebrava árvores, tacava fogo em árvores, depois que eu entrei que eu fui vendo que não era bem assim, eu estava estragando as coisas"'".

Abordando a importância da participação dos cidadãos nas questões locais e o papel do poder público, L.J. faz uma crítica abrangente: 
"O Brasil passou por vinte e cinco anos de repressão, de ditadura que não foram fáceia, ainda que na idade que eu comecei a me conscientizar a repressão estava acabando "entre aspas", mas acho que hoje existe abertura para que a gente possa trabalhar e exercitar a cidadania (...) Eu acho que o papel de uma entidade, de um Grupo Ecológico como o Cascata Branca contribui para que as pessoas comecem a questionar as "pequenas coisas" e a partir dai questionam as "grandes coisas", e a partir dai as pessoas comecem a mudar"'",

Outro entrevistado, G., cita que na sua opinião a validade da participação no Grupo Ecológico foi pela oportunidade de ter contato com a realidade dos problemas culturais, sociais e ambientais brasileiros, dando ênfase ao descaso e fala de interesse governamental em relação a essas questões.

Vários entrevistados destacaram o fato da participação no Grupo ter sensibilizado alguns ex-integrantes até o ponto de um deles, A. M., ter ingressado no curso de Engenharia Florestal da ESALQ/USP, colocando esse fato como um dos mais significativos. A própria A . M. assim respondeu a questão sobre a importância de participação no Grupo:

"Acho que a resposta está aqui, eu estar fazendo esse curso, acho que foi a mudança na minha vida. O envolvimento foi assim total, pelo menos para mim foi, nossa, foi o que me levou a estar aqui. (...) Essa fase de criança para adolescente é a fase mais gostosa e mais trabalhosa que você tem, mas é a fase de maior resposta. Foi prazeroso demais ter desenvolvido aquele trabalho e eu espero não estar reproduzindo, mas inventando, criando novos momentos, trabalhando isso porque Educação Ambiental é a minha vida".

Em relação a críticas a respeito da atuação do Grupo Ecológico, novamente A . M. faz observações bastante pertinentes, que podem ser sintetizadas na questão da falta 
de uma estratégia de ação do Grupo que buscasse um envolvimento mais efetivo dos alunos e da comunidade, além de uma melhor divisão de atividades e infra-estrutura.

Outro fato destacado por A . M. é que o Grupo nunca buscou o reconhecimento legal na forma de registro, assim como ocorreu falta de estabilidade e de planejamento, em função da centralização do poder. Também citou a falta de apoio financeiro através de uma entidade e a necessidade de um espaço físico mais adequado.

Desse conjunto de depoimentos, sintetizamos alguns pontos essenciais que serão analisados:

A existência de uma visão crítica em relação ao poder público e da classe política local seja em relação às iniciativas específicas de implantação do parque, seja em relação as questões ambientais como um todo, fruto do histórico de tentativas frustradas de sensibilização e engajamento do poder público local em propostas mais concretas e elaboradas do Grupo;

- $\quad$ A relevância pessoal da participação no Grupo Ecológico, como forma de conhecimento da realidade sócio-ambiental e construção de uma visão crítica, sendo que a oportunidade da participação no Grupo contribuiu inclusive para a opção de vida profissional de uma exintegrante;

A importância do papel das entidades ambientalistas e as limitações dos espaços disponiveis de participação dos cidadãos;

A importância da realização de eventos e atividades práticas enquanto forma de atingir os objetivos de formação do Grupo e sensibilização da população frente às questões ambientais;

- A necessidade de melhor estruturação em termos organizacionais e materiais dessas pequenas entidades ambientalistas de forma a permitir a continuidade e aperfeiçoamento da sua prática educativa e de atuação concreta frente a complexidade sócio-ambiental atual. 


\subsection{Outras iniciativas de intervenção na área da cachoeira}

Através de informações verbais, tivemos conhecimento de pelo menos mais duas iniciativas concretas visando a implantação de um Parque Municipal na área da Cachoeira antes do ingresso do autor na administração municipal, sendo uma da própria Prefeitura no ano de 1993 e outra de um funcionário da Prefeitura Municipal (mestre-deobras, eleito vereador no período 97/2000, faleceu em 99).

Em 1983 o CEPAM, atendendo solicitação da administração municipal, apresentou um estudo básico sugerindo um plano de utilização da área da Cachoeira, criando-se um Parque Municipal, sem maiores detalhamentos. Propunha-se basicamente a manutenção do campo de futebol existente, a implantação de um viveiro de mudas, algumas trilhas e lanchonetes. Este estudo, segundo consta foi arquivado, porém o autor não conseguiu resgatá-lo (perdeu-se no arquivo morto da Prefeitura).

Em 1989, um funcionário da Prefeitura, J., mestre-de-obras na época com cargo em comissão de Diretor de Serviços Públicos chegou a elaborar o seu projeto para a área.

Por meio de uma entrevista, o mesmo explicou o que the motivou a desenvolver uma proposta de uso para a área por conta própria:

" No início de 89, quando eu fui Diretor de Serviços Públicos, na gestão do prefeito José de Oliveira Souza, o "Zeca Padeiro", a gente tinha em mente que Votorantim estava meio "parado", tava uma cidade meio parada. Então eu vendo aquela Cachoeira aí, que é uma das coisas mais belas que nós temos aqui em Votorantim, eu senti que dava para ser feita alguma coisa em relação àquela Cachoeira, principalmente na área de Turismo. Foi onde eu "bolei", rascunhei um quadro, a paisagem de como deveria ser uma área turística, e paguei até um pintor para fazer a pintura de um quadro".

O quadro mostrava a área da Cachoeira com uma grande infra-estrutura de lazer do ponto de vista do autor: um grande hotel na parte alta da encosta, o represamento após a queda d'água, formando um grande lago, a implantação de um teleférico com passagem sobre a queda d'água, a implantação de uma rodoviária na área contígua junto a rodovia, 
com uma passagem subterrânea que ligaria tal rodoviária à entrada do Parque (Anexo 02).

Tratava-se de uma proposta audaciosa e de altíssimo custo, que foi desconsiderada e motivo de crítica do ex-prefeito "Zeca Padeiro" em sua entrevista:

“(...) ele me trouxe até um quadro que ele pintou de grandes dimensões, e eu falei para o Viana que era impossível, era mirabolante a idéia dele, o que ele queria fazer era para o ano...sei lá, era incrivel o que ele fez, não tinha nada de cachoeira, a cachoeira era $1 \%$ daquilo que ele fez, um prédio que parecia a torre de Babel, e outras coisas,e eu levei aquilo em gozação, não era possivel e não tinha condições naturalmente. Mas foi um lutador para que se arrumasse a cachoeira da Chave (...)".

Independente da questão da viabilidade ou não, a própria iniciativa de J. foi válida enquanto preocupação e interesse para um uso adequado para a área.

Outra intervenção, desta vez de caráter prático feita em 1997 (detalhada no item a seguir - fase institucional foi a ocupação de parte da área junto a cachoeira com uma lanchonete e infra-estrutura precária.

Um grupo de moradores do Bairro da Chave (vizinho da área), por conta própria resolveu iniciar a implantação de uma infra-estrutura mínima na área da Cachoeira. Efetuaram uma limpeza geral, colocaram tonéis adaptados para cesto de lixo, implantaram um bar/lanchonete improvisada com rede de água e energia e banheiros improvisados no local, com destaque na imprensa local. Foram inclusive colocadas "placas orientativas" que motivaram piadas do periódico local, como "Proibido nadar de cueca". De alguma forma, a comunidade local procedeu a implantação de uma infraestrutura improvisada, haja visto que a prefeitura não tinha nenhuma proposta concreta de inicio de ocupação ordenada na área.

Devido a problemas de segurança, construções sem condições mínimas de segurança e higiene, bem como de denúncias de venda irregular de bebidas alcólicas e drogas naquela região, a Prefeitura entrou com pedido de reintegração de posse e retirou todas as construções em 1998. 


\subsection{A fase institucional (1993/2000) - Encontros e Desencontros}

Como visto, a desestruturação final do Grupo Ecológico coincidiu com o ingresso do autor no quadro técnico da Prefeitura Municipal, à partir de convite feito pelo Prefeito da época. Nesse processo, teve influência a pressão exercida por $A$, que havia sido eleito vereador e integrante da bancada de apoio do Prefeito, após sua saída do PT, conforme relato pessoal do mesmo:

“ (...) Aí a gente teve a felicidade também, a formação desse Engenheiro Florestal, o Adriano, veio a trabalhar com a gente, e na época a gente teve um bom relacionamento com o ex-prefeito Erinaldo Alves, e através de uma solicitação e de algumas pressões, assim mais pressões positivas, a gente coseguiu fazer com que 0 Adriano viesse, até pelo fato de ser filho da terra, ter uma grande paixão pela terra, viesse a estar fazendo parte do corpo técnico da Prefeitura (...)".

A primeira medida tomada com o ingresso na Prefeitura foi a elaboração de um detalhado "Plano de Trabalho". Esse Plano teve o objetivo de esclarecer e traçar metas de trabalho, tendo caráter também de esclarecimento, uma vez que a Prefeitura não possuía nenhum órgão ou técnico da área florestal/ambiental em sua história. Foram detalhados os seguintes ítens:

-Implantação de Unidade de Produção de Mudas - Viveiro Municipal

-Diagnóstico das Áreas Verdes e demais Áreas Livres do Município de Votorantim

-Plano de Arborização Urbana

-Plano de Recuperação de Matas Ciliares

-Implantação do Parque Municipal da Cachoeira, que consistia na retomada da proposta original do Grupo Ecológico Cascata Branca, associada ao lançamento da idéia de tentarse apoio financeiro do Grupo Votorantim, por suas ligações históricas com a área.

Em dezembro de 1993, o autor elaborou uma "Proposta de Diagnóstico da Área da Cachoeira da Chave", encaminhada para as instâncias superiores, onde basicamente 
solicitava-se a formação de uma comissão intersetorial para o encaminhamento desse diagnóstico, envolvendo várias áreas (Engenharia Florestal, Engenharia Civil, Arquitetura, Topografia, Assistência Social, Educação/Cultura e Procuradoria), estabelecendo-se as atribuições de cada área, tendo em vista a complexidade dos problemas existentes e a necessidade de soluções integradas. Essa comissão nunca foi oficializada ou formada, iniciativa que deveria partir do Gabinete do Prefeito.

Apesar dessa situação, tentou-se dar início ao diagnóstico através da convocação de uma reunião, ocorrida em 21/02/94, com a presença de Arquiteto, Eng. Civil, Assistente Social, do colaborador do Grupo Ecológico e então vereador da situação $\mathrm{A}$ e dois ex-integrantes do Grupo Ecológico. Não compareceram representantes da Secretaria de Cultura nem da Secretaria de Educação, nem do Setor de Topografia. Nessa reunião, considerou-se a necessidade de um levantamento planialtimétrico detalhado da área, estudos hidrológicos, estaria já programado o cadastro dos moradores da área pelo setor de Assistência Social e comentou-se sobre a necessidade de listagem e reunião de todo o material histórico sobre a Cachoeira.

A administração então formalizou o interesse na implantação do Parque da Cachoeira através da aberturta de um processo no Gabinete do Prefeito, processo este que na época foi encaminhado para o autor para manifestação, em abril de 1994. Foi então anexado para análise do Prefeito o conjunto de informações e solicitações em poder do autor, a saber:

- Planta do Projeto elaborado pelo CEPAM em 1983;

-Abordagem feita pelo Plano Diretor de 1986 sobre o tema;

-Cópia da Proposta de Projeto: "Implantação do Parque Municipal da Cachoeira de Votorantim com participação da População", elaborado em 1991 pelo autor na época de maior atividade do Grupo Ecológico;

-Planta em escala 1: 1.000 da área da Cachoeira do processo de desapropriação da área (1991)

-Memorial Descritivo da área desapropriada;

-Proposta de Diagnóstico feita em dezembro/93 pelo autor envolvendo a participação de vários setores da Prefeitura; 
-Relato da reunião ocorrida em 21/02/94 sobre o assunto;

-Relatório de uma visita feita pelo autor e Arquiteto da Prefeitura no Parque das Lavras (Salto, SP), visando colher idéias para o Parque da Cachoeira;

No oficio, reiterou-se o pedido de formação de uma comissão oficial de funcionários de várias áreas para a viabilização do diagnóstico, bem como da viabilização de uma primeira reunião dessa comissão. Também não houve qualquer retorno das proposições de encaminhamentos colocadas nesse oficio.

Nesse período, através da imprensa, divulgou-se então (20/03/94) que o Prefeito estaria contratando uma empresa particular para a execução do Projeto, cujo edital já estaria em fase final de elaboração. Esse processo foi definido e detalhado sem qualquer participação de técnicos da Prefeitura, nem mesmo na elaboração do edital, processo fechado na qual apenas o Secretário de Obras teve envolvimento. Em paralelo, nenhuma das propostas de encaminhamento sugeridas pelo autor foi colocada em prática, com exceção do levantamento planialtimétrico, que seria necessário para o desenvolvimento do projeto pela enpresa vencedora da licitação.

Caberia ressaltar que naquele momento (ano de 1994) o vereador e excolaborador do Grupo Ecológico Cascata Branca, A, após o período de composição da bancada de apoio, passou a fazer uma oposição ferrenha em função dos impasses à respeito do grupo dos sem-teto por ele coordenado na viabilização da implantação do loteamento popular e de uma politica habitacional para a população de baixa renda.

Ainda em 1994 (julho), o autor insistia no encaminhamento de uma série de proposições relativos à estruturação legal e material do setor da Prefeitura, incluindo-se: a análise da Proposta do "Código do Verde Municipal" (legislação relativa a normatização das áreas de manejo da arborização urbana); proposta de implantação do COMDEMA (Conselho Municipal de Defesa do Meio Ambiente (lei já existente desde 1985); proposta de estudos para implantação da coleta seletiva de lixo e a cobrança de um retorno do parecer dado pelo autor em 07/04/94, em relação à proposta de Implantação do Parque da Cachoeira, além de outros assuntos pontuais. Novamente, não houve qualquer retorno por escrito ou verbal em relação à proposta. 
Em julho de 1995, finaliza-se o processo de contratação de uma empresa particular para a implantação de um projeto paisagístico para a área, conforme artigos na imprensa na época. Venceu a empresa Luciano Fiaschii Arquitetura e Paisagismo, com uma prazo de 120 dias para a apresentação da proposta e custo de $\mathrm{R} \$ 82.000,00$ (oitenta $\mathrm{e}$ dois mil reais). Porém, nesse mesmo artigo, foi colocado que o Projeto não iria ser colocado em prática: "Erinaldo admitiu que a execução do projeto não será na sua gestão, entretanto ele quer definir uma proposta para a criação do Parque da Cachoeira ainda no seu governo para assegurar que não haja uma ocupação individa na área. Para isso, contratou uma empresa especializada que irá elaborar um projeto responsável e com visão voltada ao futuro do município" (Folha de Votorantim, 18/07/95, folha 05).

O projeto então foi desenvolvido pela Empresa, sem envolvimento dos técnicos da Prefeitura. Já estaria então definido a forma de encaminhamento de implantação de um Parque na área, de forma não participativa e sem perspectiva de ser colocado em prática.

Essa postura provocou um posicionamento duro de um ex-integrante do Grupo Ecológico, L., que acompanhou a frustrada tentativa do autor de iniciar internamente uma movimentação para a implantação do Parque da Cachoeira e outras iniciativas relativas à questão ambiental local, divulgada na forma de "espaço do leitor" divulgada no jornais local e regional, aqui transcrita e função de sintetizar o posicionamento das pessoas que participaram dos anos de luta em prol da Proposta participativa:

\section{" A HISTÓRIA SE REPETE}

Quando em 1990 unimos um grupo de cidadãos interessados no mesmo propósito, o de recuperar e implantar um parque na área de um dos maiores Patrimônios Históricos de nosso município - a Cachoeira de Votorantim - havíamos avançado e muito nas negociações. Reunimos por três vezes na Biblioteca Municipal: professores da USP - Escola Superior de Agricultura "Luiz de Queiroz", engenheiros do Centro de Apoio Florestal do Grupo Votorantim (proprietário da área à época), técnicos da CETESB e DEPRN - Secretaria do Meio Ambiente do Estado de São Paulo, 
além de lideranças comunitárias de nossa cidade. Mas nada de prático pôde ser feito, pois não havia nessas reuniões - apesar dos insistentes convites - um representante do órgão que deveria ser o mais interessado na questão - a Prefeitura Municipal.

Esta falta de vontade política foi até mesmo motivo de uma carta de repúdio, por parte dos participantes do $\mathrm{I}^{\circ}$ Encontro Nacional de Educação Ambiental, ocorrido em Curitiba-PR em 1991, enviada ao Prefeito da época e Câmara Municipal de Votorantim.

O tempo passou, o prefeito mudou e lá fomos novamente. $\mathrm{O}$ Sr. Erinaldo nos recebeu em seu gabinete no início de sua gestão e nos prometeu estudar a proposta. Mas o descaso foi o mesmo, até pior, já que recebemos notícias pelos jornais de que cerca de $\mathrm{R} \$$ $82.000,00$ serãogastos para que um projeto para a área não saia novamente do papel, contratando uma empresa particular para tal. Enquanto isso a área da Cachoeira vai cumprindo o mesmo triste destino de tantas áreas da cidade, se degradando a cada dia. Quem assegura que ela não terá o mesmo destino que a Cachoeira dos Guimarães?

Gostaria de apenas saber, Sr. Prefeito, o que um projeto de R\$ 82.000,00 tem de melhor que o planejamento e implantação de um projeto com a participação da população e envolvimento de universidades como a USP e mesmo órgãos públicos como o Cepam e Departamento de Projetos da Paisagem da Secretaria do Meio Ambiente, que contam com profissionais de altíssimo gabarito, além de um "pequeno detalhe": o baixo custo? Cabe lembrar ainda que o povo de Votorantim paga por topógrafos, engenheiros e arquitetos, que poderiam ter participação neste projeto. 
Admira-se saber que o Sr. Prefeito, sendo um educador, não reconheça o valor de projetos que envolvam as universidades, órgão públicos e a comunidade, nos quais beneficios não só referentes à questão ambiental, como também saúde, educação e cultura pode ser obtidos"(Jornal Cruzeiro do Sul,29/08/95, p.02).

Esse artigo possivelmente teve grande repercussão na Prefeitura e classe política local, possivelmente contribuindo para a inviabilização do encaminhamento da propostas gerais em termos de estruturação da área de meio ambiente na Prefeitura e inclusive motivando, por parte de um grupo de vereadores da oposição liderados por A, ex-colaborador do Grupo Ecológico Cascata Branca, a instauração de uma inquérito civil junto à Promotoria Pública principalmente em função do então Prefeito ter declarado na imprensa que não iria executar o Projeto. Segundo a interpretação desses vereadores, isso caracterizaria "mau uso de dinheiro público", envolvendo a contratação de um " projeto de papel" que não iria ser implantado naquela gestão, como realmente não o foi. $O$ autor inclusive foi convocado pela Promotoria para prestar depoimento em relação ao fato, onde o mesmo expôs todo seu envolvimento com a questão e as tentativas frustradas de, como técnico da área, iniciar um trabalho concreto a partir de um diagnóstico geral com o envolvimento de vários setores da Prefeitura. Não se sabe o resultado do andamento desse inquérito civil, porém presume-se que pode ter contribuído para que qualquer iniciativa do autor, ligada direta ou indiretamente com a questão ambiental na Prefeitura, fosse totalmente desconsiderada.

Ainda em 1995 destaca-se novamente o destaque dado para a área da Cachoeira dentro de um levantamento do potencial turístico do município feito por técnicos da Secretaria Estadual de Turismo, que resultou na emissão do "selo de potencial turístico" emitido pela EMBRATUR.

O ano de 1996 não teve nada de efetivo em relação à área da Cachoeira, estando o autor concentrado apenas em atividades de rotina, desvinculadas de qualquer proposta mais articulada de atuação em relação à questão ambiental como um todo, estando todas as suas propostas e iniciativas mais gerais sem qualquer tipo de manifestação por parte do Gabinete do Prefeito. 
Possivelmente em função da pressão dos vereadores da oposição em relação ao Projeto contratado que não seria executado, no segundo semestre de 1996 aconteceu um fato bastante interessante: vários artigos na imprensa local e regional afirmando que a Prefeitura já estaria iniciando a implantação do Parque da Cachoeira, através do plantio de mudas de árvores nativas nas encostas e desassoreamento de trechos do rio Sorocaba.

$\mathrm{O}$ fato é que o plantio foi iniciado sem qualquer cuidado técnico, aproveitando-se do período de férias do autor, responsável técnico pelo viveiro, plantando-se espécies sem qualquer critério técnico em termos de associação dentro do processo de sucessão secundária, inclusive com uso de espécies exóticas. Não foi efetuado nenhuma manutenção, sendo o período (julho) de seca, nem efetuada irrigação, nem isolamento e vigilância, o que levou ao fracasso total do plantio. Na opinião do autor, a determinação do plantio aleatório em época inadequada e a divulgação dos artigos na imprensa foi uma tentativa de "justificar" a opinião pública, vereadores da oposição e ministério público de que o projeto estaria se iniciando, o que não condizia com a realidade. Nem mesmo o cercamento, solicitado pelo autor desde novembro de 1993, foi efetuado. Também estava em andamento o período eleitoral, com a questão do Parque da Cachoeira sendo também usado como crítica ao grupo político dominante pela oposição.

A eleição teve como ganhador João Souto Neto, que foi vice-prefeito da gestão anterior, representando a continuidade das propostas do grupo político que estava no poder na gestão anterior, inclusive com o ex-prefeito fazendo parte do Secretariado durante o primeiro ano da administração (Secretário da Educação). Em artigo logo após a eleição, onde manifestou em linhas gerais suas propostas de trabalho, encontramos a seguinte colocação:

"Souto garante que pretende priorizar nas áreas de esporte, lazer e da cultura": "Hoje, Votorantim não tem um lugar para lazer, principalmente destinado aos jovens. Isso também acontece devido à proximidade de Sorocaba. Agora que alguns problemas da cidade já estão resolvidos, nós temos condições de partir para essa área, onde nós pretendemos desenvolver projetos, como o do Parque da Cachoeira, que já está pronto. No parque está previsto a construção 
do mini-teatro municipal e de uma oficina cultural." (Jornal Cruzeiro do Sul, 08/10/96, página 10).

Cumpriria destacar que no "Plano de Governo" do então candidato, distribuído para a população na época da campanha, o Parque da Cachoeira estava incluído na proposta:

"Vamos priorizar a construção do Parque da Cachoeira; o Teatro Municipal e a Oficina Cultural (...) Com o Parque da Cachoeira e a Praça de Eventos pretendemos aproveitar amplamente para realização de shows, feiras e exposições de produtos produzidos em nossa cidade, abrindo maior espaço para o turismo, bem como oferecerendo condições de gerações de novos empregos" (Plano de Governo, 1996, p.05).

Também foi incluído um item específico intitulado "Saneamento Básico e Meio Ambiente", onde, além dos aspectos relativos a implantação de adutoras, construção de reservatórios e estações de tratamento de esgoto, colocou também:

“ O nosso programa inclui ainda a criação de uma divisão de meio ambiente junto a Secretaria de Serviços Públicos, através da qual vamos promover uma política ambiental no município voltada para a qualidade de vida da população."(Programa de Governo,1996, p.09).

$\mathrm{O}$ autor, com a esperança, em função dos compromissos expostos no Plano de Governo do candidato vencedor, especificamente em relação à estruturação de uma setor de meio ambiente, partiu para a elaboração de um documento, que foi apresentado às instância superiores em 18/02/97, com o objetivo de iniciar uma discussão interna para a viabilização de uma série de propostas. Com finalidade didática, uma vez que a Secretaria de Serviços Públicos à qual o autor é subordinado passou a ser comandada por um topógrafo da Prefeitura sem formação na ambiental, continha os seguintes itens:

- O que é uma política de meio ambiente (introdução);

-Questões importantes para resolver (listagem dos problemas ambientais mais importantes e propostas para iniciar uma atuação frente à cada um deles); 
-Política Municipal de Meio Ambiente: Princípios, Objetivo e Instrumentos;

-O que temos nas nossas leis (síntese da legislação ambiental federal e municipal), com destaque para a revisão no Plano Diretor original, de 1986, feita pela Lei $n^{\circ} 1.231 / 96$ ). Essa revisão incluiu um item específico denominado "Sistema de Áreas Verdes e Estrutura Ambiental", com a discriminação de áreas com potencial para implantação de parques urbanos, com novamente destaque para a área da Cachoeira;

-Situação Atual, com a apresentação do deficitário quadro de recursos humanos do Setor de Parque e Jardins e finalmente

-Propostas para discussão, que pela sua importância para nossa análise merece um detalhamento maior, sendo aqui transcrita integralmente:

\section{“6. PROPOSTA PARA DISCUSSÃO}

É necessário definir, primeiramente, frente ao exposto principalmente em relação ao problema existentes, atribuições legais da Prefeitura e disponibilidade deste técnico em coordenar a área de meio ambiente, qual a real perspectiva para $o$ desenvolvimento dessa área, de forma a ter uma atuação efetiva e não apenas de "apagar incêndio". Os recentes problemas da Prefeitura junto à Polícia Florestal em relação às obras de terraplanagem do loteamento popular do Itapeva e obras de acesso a zona industrial ao lado da Dixie/Laleka, demonstram a necessidade de um setor para tratar essas questões.

É sabido que existe um grande preconceito em relação à questão ambiental em função das restrições legais, porém a solução não é ficar questionando leis federais e sim ter uma estrutura dentro da Prefeitura que se antecipe a esses problemas e demonstre que é plenamente possível e desejável que se compatibilize a implantação de obras e desenvolvimento econômico com a conservação e recuperação ambientais. 
Em relação aos recursos necessários, os investimentos são os normais dentro da estrutura administrativa, que podem ser incorporados dentro do orçamento anual.

Foi apresentada, na Síntese de Atividades do Setor de Parque e Jardins do período setembro/93 a dezembro/96, para discussão, uma proposta de criação de uma Diretoria de Meio Ambiente.

Dentro desse mesmo documento (Síntese de Atividades), entregue ao G.S./SESP e ao G.P. em novembro/96, segue uma série de propostas que aqui são transcritas para uma discussão efetiva (até o momento não feita):

\section{PROPOSTAS PARA 1997}

- IMPlantaÇÃo dA POlítica MUNICIPAL DE MEIO AMBIENTE

- VIABILIZAÇÃo DOS PROJETOS E PROPOSTAS DO SETOR JÁ APRESENTADOS: IMPLANTAÇÃo DO Código do VERDE MUNICIPAL (EM ESTUDO DESDE 1994), IMPLANTAÇÃO DO CONDEMA-CONSELHO MUNICIPAL DE DEFESA DO MEIO AMBIENTE (PREVISTO EM LEI DESDE 1985) E OUTROS

- ESTUdO DA CRIAÇÃO DE UM SETOR ESPECÍfICO DE MEIO AMBIENTE, COM ATRIBUIÇÕES E ESTRUTURAÇÃO ADEQUADA (DIRETORIA DE MEIO AMBIENTE)

- VIABILIZAÇÃO DE CONVÊNIOS COM UNIVERSIDADES E INSTITUTOS DE PESQUISA PARA O DESENVOLVIMENTO DE PROJETOS NA ÁREA DE MEIO AMBIENTE, COMO POR EXEMPLO UNISO, PUC-SOROCABA (BIOLOGIA) E ESCOLA SUPERIOR DE AGRICULTURA "LUIZ DE QUEIROZ"DA USP, BUSCAR APOIO DA SECRETARIA DE MEIO 
AMBIENTE DO ESTADO DE SÃO PAULO (DEP. FÁBIO FELDMANN, AMBIENTALISTA)

- viabilizar o desenVOlVIMENTo com recursos PRÓPRIOS E POR MEIO DE CONVÊNIOS DE PROJETOS COMO:

- LEVANTAMENTO DO POTENCIAL DE TURISMO ECOLÓGICO DE VOTORANTIM

- MAPEAMENTO DOS REMANESCENTES DE FLORESTAS

E DEMAIS FORMAS DE VEGETAÇÃO NATURAL DO MUNICÍPIO

- IEVANTAMENTO DA ARBORIZAÇÃo URBANA E DOS ESPAÇOS LIVRES DE USO PÚBLICO DO MUNICÍPIO (PRAÇAS E OUTROS)

- REVISÃo NO PLANO DIRETOR DE FORMA A INCORPORAR A QUESTÃO AMBIENTAL (ZONEAMENTO AGROECOLÓGICO)

- IMPLANTAÇÃO DE UNIDADES DE CONSERVAÇÃO EM ÁREAS DE RELEVANTE INTERESSE ECOLÓGICO (SERRA DE SÃO FRANCISCO, MATAS NAS MARGENS DA REPRESA ITUPARARANGA, JATAII III)

- IMPLANTAÇÃo DO SISTEMA MUNICIPAL DE INFORMAÇÕES AMBIENTAIS DE ACESSO À POPULAÇÃO

- Plano municipal de educaÇão ambiental FORMAL (NAS ESCOLAS) E INFORMAL (MEIOS DE COMUNICAÇÃO, ASSOCIAÇÕES DE MORADORES E OUTROS), INTEGRADO À SECRETARIA DE EDUCAÇÃO

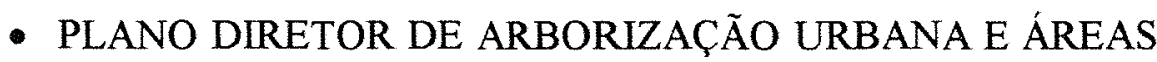
VERDES 
- plano municipal de recuperaÇão de Áreas DEGRADADAS (ENCOSTAS E MORROS) E MATAS CILIARES

- Plano MUNICIPAL DE DESTINAÇÃo DE RESÍDUOS SÓLIDOS URBANOS E COLETA SELETIVA DE LIXO

- eFETIVA PARTICIPAÇÃo DA PMV NO CERISOCONSÓRCIO DE DESENVOLVIMENTO E RECUPERAÇÃo DA BACIA DO RIO SOROCABA-CONTINUIDADE DE OBRAS DE DESPOLUIÇÃO DO RIO

Finalizando, espera-se que este documento tenha cumprido a função de mostrar que o investimento em uma estrutura ambiental dentro da prefeitura, além de uma obrigação legal, é uma necessidade premente frente a situação atual. A opinião pública reage favoravelmente às iniciativas do poder público nessa área, de grande repercussão na Mídia, mais um argumento para encarar com mais seriedade e profissionalismo a administração dos recursos naturais dentro do município. A VONTADE POLítICA é o elemento principal para se mostrar que Votorantim está cumprindo suas responsabilidades e investindo no bem-estar e qualidade de vida da presente e futuras gerações" (Melo, 1997).

Esse documento, enviado para a imprensa local conforme iniciativa do Secretário de Serviços Públicos, motivou a elaboração de uma série de três reportagens especiais de página inteira com grande destaque na capa por parte do periódico local, precedidas de um "SOS Natureza" ("Prefeitura tem plano para o meio ambiente", Folha de Votorantim do dia 22/02/97, p.01 e 03); "O desafio da Coleta Seletiva", Folha de Votorantim de 01/03/97, p. 01 e 09) e "Só leis não garantem a proteção do meio ambiente", Folha de Votorantim de 08/03/97, p. 01 e 06). 
Apesar do destaque da imprensa, os artigos não motivaram nenhuma atitude concreta por parte do Gabinete do Prefeito em viabilizar a discussão das questões levantadas. Até a Promotoria Pública de Votorantim pediu uma cópia do estudo na época, sem retorno posterior.

Foi solicitado por pelo menos duas vezes uma audiência com o Prefeito naquela época, por meio de comunicações internas (por escrito) para a discussão daqueles temas, sem sucesso.

Até a presente data (janeiro de 2000) não houve qualquer tipo de retorno, verbal ou escrito, para a discussão daquelas propostas. A única iniciativa do Executivo em relação a área ambiental foi o envio e a aprovação em tempo recorde uma alteração em uma Lei Municipal (1067/93) que definia uma faixa de 20 metros nas margens de rios, córregos e lagoas em Votorantim, alterando (diminuindo) essa faixa para 15 metros.

A única oportunidade em que o Prefeito convocou o autor para uma reunião no Gabinete foi em novembro de 1999 para discutir os efeitos de um parecer técnico emitido pelo mesmo alertando sobre os problemas na retirada de sub-solo para aterro de uma encosta de um morro situado na área urbana, próximo a áreas consideradas de risco, sendo que tal paralisação por questões ambientais poderia dificultar o andamento das obras de duplicação de um trecho de cerca de cinco quilômetros do ramal 103 da rodovia SP-79, que liga Votorantim a Piedade, uma das obras prioritárias da administração.

Em relação especificamente ao Projeto da Cachoeira, o autor, conforme contatos com seu superior nos primeiros meses da adminstração 97/200, Secretário de Serviços Públicos, solicitou por escrito por três vezes ao Secretário de Obras o acesso ao Projeto elaborado a quase dois anos atrás pela Empresa particular contratada, sem ser atendido. Era uma situação complicada: foi negado o acesso de um servidor público a um projeto de interesse público pago pela Prefeitura.

Um fato novo e bastante interessante aconteceu nessa época, relativa a área da Cachoeira: um grupo de moradores do Bairro da Chave (vizinho da área), por conta própria resolveu iniciar a implantação de uma infra-estrutura mínima na área da Cachoeira. Efetuaram uma limpeza geral, colocaram tonéis adaptados para cesto de lixo, implantaram um bar/lanchonete improvisada com rede de água e energia e banheiros 
improvisados no local, com destaque na imprensa local. Foram inclusive colocadas "placas orientativas" que motivaram piadas do periódico local, como "Proibido nadar de cueca". De alguma forma, a comunidade local procedeu a implantação de uma infraestrutura improvisada, haja visto que a prefeitura não tinha nenhuma proposta concreta de início de ocupação ordenada na área.

Nesse período também a Cachoeira foi destaque na imprensa regional, em um artigo sobre as mortes por afogamento na região. Esse artigo, intitulado "Dia de Sol Feriado em lagoas tem 02 mortes", trazia a seguinte descrição da área:

"Em Votorantim, crianças e adultos brincavam na cachoeira da Chave, nome que faz referência ao bairro onde se localiza a queda d'água. Próximo ao local, um barracão tocava música $\mathrm{e}$ comercializava bebidas e salgados. A área, que pertence a Prefeitura de Votorantim, não tem infra-estrutura, lixo e até dejetos humanos são vistos pelo morro por onde desce a água. Mesmo assim, sem outras op̧̧ões viáveis, as pessoas brincam na cachoeira.

Frequentadores do local chegaram a sugerir que a Prefeitura construísse quiosques num terreno próximo a Cachoeira $\mathrm{e}$ oferecesse melhores condições para as pessoas brincarem. Disseram que a Prefeitura poderia até cobrar $R \$ 1,00$ para a manutenção da área, mantendo o local um pólo de atração para a cidade."(Jornal Cruzeiro do Sul, 02/05/97, p.05).

Nesse ano, por meio do poder público a área da cachoeira foi destaque em um artigo sobre a Lei de Diretrizes Orçamentárias para o exercício de 1998:

“(...) Também estão elencadas nas metas do prefeito a construção do Parque Natural da Cachoeira, que prevê investimentos em infraestrutura para fazer do local uma atrativo turístico para a cidade. $O$ projeto já existe e engloba toda a área em volta da cachoeira da Chave, que receberá tratamento paisagistico, arborização, equipamentos de laze e mirantes." (Folha de Votorantim, 17/07/97, p. 03). 
Nesse periodo também detaca-se a cobrança de um vereador da oposição através da imprensa, onde o mesmo teve aprovado um requerimento questionando o Prefeito sobre o que já havia sido feito para a implantação do projeto do parque (artigo "Vereador cobra implantação do Parque da Cachoeira", publicado no jornal Folha de Votorantim em 08/05/97).

Ainda em 1997, a imagem da Cachoeira foi novamente utilizada na edição comemorativa do jornal local sobre os 34 anos de emancipação político-administrativa (Folha de Votorantim, 08/12/97), na "síntese da nossa história" (página 02). Também foi citada em entrevista com o prefeito quando perguntado sobre os planos para a área de turismo:

"Queremos já à partir do próximo ano, se as condições financeiras permitirem,iniciar a execução do Projeto do Parque da Cachoeira, em parceira com empresas, logicamente" (Folha de Votorantim, 08/12/97, p.20)

A imagem da Cachoeira também foi utilizada na elaboração de um calendário de 1998, elaborado pela Prefeitura e distribuído para toda a população.

Em 1998, o único fato relevante em relação à área da cachoeira foi o confronto entre o grupo que fez a "ocupação" da área e a prefeitura. Membros do Conselho Tutelar da criança denunciaram a venda de bebidas alcólicas para menores na área e indícios de consumo de drogas em alguns pontos da cachoeira. A Prefeitura obteve a reintegração de posse após a tentativa frustrada de solicitar a desocupação da área através de uma notificação.

Em 26/02/98, um grupo de moradores e freqüentadores da Cachoeira realizou uma manifestação, com faixas, solicitando a permanência da lanchonete da área, tendo em vista a ordem judicial já expedida para a desocupação da mesma, protocolando inclusive um abaixo assinado pedindo a permanência da lanchonete no bairro (Jornal Cruzeiro do Sul, 26/02/98,p.10). A iniciativa não surtiu efeito e a área foi desocupada, com a retirada de todas as instalações improvisadas.

Após essa data, nada de significativo foi colocado em prática em relação à implantação do Parque da Cachoeira por parte da Prefeitura ou indivíduos/grupos 
organizados, com exceção de novas cobranças de vereadores da oposição em relação ao início das obras e a lembrança/uso da imagem da Cachoeira nas publicações comemorativas (data da instalação do município, 27/03 e aniversário da cidade, 08/12). Em relação às proposições do autor colocadas para análise do Gabinete no início da Administração também nada foi sequer discutido.

$\mathrm{Na}$ estrutura de cargos, a administração 97/2000 criou um único cargo em comissão de "Chefe de Serviço de Proteção do Meio Ambiente" (terceiro escalão), que tinha como pré-requisito "preferencialmente nivel superior". O cargo foi ocupado por um operário aposentado da Fábrica de Cimento Votoran e Tesoureiro do PSDB na época, de baixo nível de escolaridade porém ativo participante da campanha eleitoral e ferrenho defensor do Prefeito anterior, sem qualquer formação técnica na área ambiental. Suas atividades, já desempenhadas na gestão anterior (Erinaldo Alves da Silva-PSDB), restringiram-se principalmente ao acompanhamento da execução dos serviços de equipes de capinação, roçagem e remoção de entulho de áreas públicas. Com a morte por problemas de saúde desse funcionário em dezembro de 1999, o cargo foi transmitido para outro servidor, motorista do corpo efetivo de funcionários da Prefeitura que já ocupava cargo em comissão em um escalão inferior. Este continuou desempenhando as mesmas atividades, ligadas à rotina da execução de serviços de manutenção de estradas, terraplanagens, aterros e outras atividades da frota de máquinas e caminhões da Prefeitura, sem qualquer relação com a área ambiental.

Esse relato sintetiza os cerca de 06 anos (setembro de 1993 até a presente data) em que o autor passou do "status" de ambientalista, com ativa atuação, para o de técnico de administração, com atuação limitada e restrita aos serviços cotidianos da administração: orientação técnica do viveiro de mudas, execução de vistorias relativas ao corte de árvores isoladas, recuperação paisagística de praças, elaboração de pareceres técnicos, encaminhamentos de projetos de obras da Prefeitura para licenciamento ambiental junto aos órgãos estaduais e federais (DEPRN, IBAMA), plantio de árvores para revegetação de áreas degradadas e outras, caracterizadas pela desarticulação, falta de recursos humanos e materiais, isolamento em relação às outras atividades e desvinculadas de qualquer projeto mais amplo de estruturação de uma política ambiental. 
Não se obteve retorno de nenhum dos projetos apresentados desde 1993 (Estruturação de um setor de meio ambiente, implantação do "Código do Verde", criação do COMDEMA e outros).

\subsection{Depoimentos de ex-prefeitos: a visão do poder público local}

Até então baseamos nossa análise no relato das tentativas do autor em iniciar um trabalho específico dentro da estrutura administrativa da Prefeitura de Votorantim em relação à área da cachoeira e de forma geral sua tentativa frustrada de implantação de uma Política Municipal de Meio Ambiente, envolvendo tanto uma estrutura operacional (recursos humanos e materiais) quanto de criação de uma estrutura administrativa dentro do organograma. Como visto, resumidamente estas tentativas se limitaram a propostas de legislações e de planos de ação que não foram sequer discutidas, desde seu ingresso em setembro de 1993 até a presente data.

Lembramos também que na época da atuação do Grupo Ecológico, a relação com a Prefeitura foi de certa forma conflituosa, onde por um lado existia a disponibilidade de colaborar na realização de eventos e necessidade materiais pontuais do Grupo, mas por outro lado as propostas mais abrangentes e que necessitavam de um engajamento e trabalho conjunto não foram viabilizadas, basicamente a iniciativa de proposta participativa de implantação do Parque na área da Cachoeira.

Fundamental nessa análise então é buscarmos saber as opiniões do Poder Público na voz dos Prefeitos, de forma a aprofundarmos nossa discussão sobre o papel do Executivo dentro da questão ambiental local. Nos vários estudos sobre Política Municipal de Meio Ambiente, sentimos que faltou justamente uma análise que considerasse as opiniões das pessoas que naquele momento eram as responsáveis pela administração da cidade e pela aplicação das políticas públicas, concentrando-se mais na análise crítica de programas e projetos desenvolvidos e problemas enfrentados.

Tendo em vista os dois momentos distintos abordados no presente estudo: a época de intensa atuação do Grupo Ecológico Cascata Branca, que coincidiu com a gestão do Sr. José de Oliveira Souza ("Zeca Padeiro"), prefeito de 1989 a 1992 e o período a partir 
do qual o autor passou ai integrar os quadros da Prefeitura (a partir de 1993), que coincidiu com a terceira gestão do professor Erinaldo Alves da Silva (1993 a 1996), definiu-se pela necessidade de entrevistar a ambos.

$O$ roteiro de entrevista estruturou-se de perguntas mais gerais, envolvendo desde como se deu o envolvimento com a política (trajetória política), principais realizações da administração segundo a opinião dos mesmos, até a abordagem de questões ambientais gerais do município e aprofundando-se sobre a opinião sobre a atuação do Grupo Ecológico, sobre as propostas do mesmo e depois sobre as relações entre poder público, entidades ambientalistas e a questão ambiental.

O Depoimento dos ex-prefeitos José de Oliveira Souza (89/92) e Erinaldo Alvesda Silva $(73 / 76 ; 83 / 88 ; 93 / 96)$ praticamente abrangem todo o período de vida autônoma do município de Votorantim, tendo em vista que os entrevistados participam da vida política desde a mobilização para o desmembramento de Sorocaba, no início dos $\operatorname{anos} 60$.

Devido aos momentos distintos nos quais os Prefeitos interagiram com o Grupo Ecológico e com o autor, existiram perguntas mais específicas que se aprofundaram sobre os temas abordados.

A estrutura de roteiro não seguiu um modelo rígido e foi a seguinte, de forma geral:

1. Envolvimento dos entrevistados com a política (trajetória política)

2. Principais realizações da administração

3. A existência de problemas ambientais em Votorantim

4. Opiniões sobre a atuação do Grupo Ecológico Cascata Branca

5. Questões específicas em função do momento analisado

6. Relações entre política e meio ambiente e parceiras entre o poder público e organizações não-governamentais.

Entrevista com Sr. José de Olivera Souza ("Zeca Padeiro"), prefeito no período de 1989 a 1992 
Questão: Trajetória Política

"Zeca" inicia sua entrevista de forma inusitada:

"Eu sempre fui um "político apolítico", eu nunca gostei de política.

Em 1962, quando Votorantim ainda era distrito de Sorocaba, eu fui inscrito contra minha vontade no PTB. E de lá começou, eu fui eleito em 1962, em 63, como vereador representando Votorantim em Sorocaba".

Lembramos que naquela época Votorantim era um distrito marginalizado e esquecido de Sorocaba, conforme relata o entrevistado, após citar seu envolvimento no movimento iniciado para a emancipação político-administrativa do então distrito:

" Votorantim era um bairro, um distrito abandonado, naquele tempo não tinha nada, e começamos assim, lutando, organizamos uma luta, e tinham os contra, tinham os ferrenhos contra, mas Graças a Deus foi tudo bem, Votorantim ganhou com isso porque naturalmente, porque a emancipação trouxe tudo que Votorantim precisava".

Destacou a participação dos demais administradores:

"Nós que começamos a administração com 08 ou 10 mil habitantes, no máximo 12 , hoje temos 10 vezes mais, ganhamos um município bem organizado. Eu creio que não somente eu que fui prefeito, mas o Erinaldo, o Luizinho, o Rangel, todos aqueles que passaram pela Prefeiutura, dedicaram todo o seu tempo para que houvesse essa melhora em Votorantim. Hoje é uma cidade que nos orgulhamos, eu me orgulho de Votorantim."

Portanto, o ex-prefeito mostrou um envolvimento profundo com a política municipal até mesmo antes da emancipação, quando era vereador por Sorocaba representando o então Distrito de Votorantim. Disputou por sucessivas vezes a Prefeitura, tendo conseguido se elegar em 89, após a segunda administração de Erinaldo Alves da Silva, provocando a mudança no grupo político que comandava a Prefeitura na época. Naquele momento, eram ambos adversários políticos. 
Principais realizações da administração

"Zeca Padeiro" destacou com um dos principais problemas e preocupações da administração a água, o Prefeito anterior havia concluído a nova estação de tratamento mas não havia investido o suficiente na distribuição:

" Eu logo que assumi, um grave problema de Votorantim, que o Erinaldo começou a resolver era o problema da água. Era um problema tremendo, Votorantim não tinha capacidade nehuma de atendimento nos bairros. Ele fez o tratamento de água mas não teve tempo de fazer a expansão para os bairros (...) a água foi o principal escopo da minha administração."

Outra realização citada foi a construção de um novo prédio para a Prefeitura:

"o que me preocupava também era com aquela prefeitura velha, arcaica, eu tinha vergonha de receber as pessoas de fora como Prefeito (...) não era uma bela Prefeitura, mas pelo menos atende condignamente os nossos funcionários e o povo de Votorantim, foi uma das grandes vitórias."

Citou também que procurou atender a Saúde. Considerou também que outra grande vitória foi em relação à segurança pública, com a instalação do quadragésimo batalhão da Polícia Militar em Votorantim, por meio de contato direto com o Governo do Estado na época, que estava a princípio destinado para ser implantado em Itu.

"Zeca" termina sua fala novamente ressaltando a atuação dos demais Prefeitos: "...todos os Prefeitos de Votorantim, sem exceção, todos lutaram para que Votorantim fosse o que é hoje: de um bairro pobre e miserável para uma cidade média."

Existência de problemas ambientais em Votorantim 
"Zeca" foi categórico em se manifestar pelo fato que na sua opinião não existem problemas ambientais significativos em Votorantim, sendo restrito anteriormente a problemas de poluição provocados pelas grandes indústrias:

"De fato hoje, esse mal está quase sanado. Nós tínhamos antigamente uma grande poluição, mormente pela manhã, quando a fábrica de cimento poluía o rio, os ares, a Votocel tinha também que tinha aquela poeira, como o cimento, e poluía bastante Votorantim. Mas com a compreensão da Votorantim, dos dirigentes, dos diretores, chegou-se a fazer uma coisa fantástica lá em Santa Helena, que foi filtrar; pois não era possível, você chegava em Santa Helena e em dez minutos, você ficava cheio de pó (...) mas hoje $90 \%$ nós estamos despoluídos. A Metidieri conseguiu também fazer o serviço de saneamento do esgoto, da água, e Graças a Deus Votorantim é uma cidade privilegiada."

Essa opinião feria frontalmente a opinião dos ex-integrantes do Grupo Ecológico, que inclusive chegaram a se manifestar publicamente a respeito no artigo "Sensibilidade Ambiental X Desinteresse"' publicado em /91 na tentativa de buscar a compreensão pela falta de atitudes concretar da administração em relação aos problemas ambientais locais e espeficicamente em relação à proposta de implantação do Parque da Cachoeira. Denota na opinião do autor uma visão "simplista" da questão limitada apenas aos efeitos que eram mais visiveis e sentidos que ocorreram na época do "milagre brasileiro", com a forte expansão urbano-industrial e consequente poluição. Também as medidas de controle de poluição não foram apenas iniciativas isoladas e altruístas de diretores industriais e sim fruto do início do trabalho de fiscalização ambiental por parte da Companhia Estadual de Saneamento e Controle Ambiental, a CETESB e da estruturação de uma política de controle da poluição por parte do Estado. Certamente essa visão "simplista" da questão ambiental local provavelmente afetou a forma do então Prefeito perceber e encaminhar as propostas do Grupo Ecológico, uma vez que segundo os mesmos essas questões não tinham relevância. 
Formas de autuação da Administração frente à área ambiental

Aparentemente não houve uma compreensão da questão por parte do entrevistado ou o autor não foi claro na elaboração da pergunta, pois o ex-prefeito ao responder essa questão ("Como o Sr. acha que a Administração pode atuar nessa área ambiental?) limitou-se a citar que tinha preocupação com a preservação das matas e com sua iniciativa em implantar o Parque do Matão, através da concessão na forma de comodata da área para um particular explorar por um periodo de 15 anos, sendo toda a infraestrutura existente sob responsabilidade desse empreendedor particular e cobrado o ingresso dos visitantes:

"Meu pensamento sempre foi esse: preservar as matas, as matas ciliares, antigamente se cortava muita madeira na beira do rio, aliás quando eu adentrei eu notei que havia uma certa preocupação, você deve se lembrar disso, com o que é hoje o zoológico do Matão. $O$ Matão era um ninho de marginais, era uma vergonha, e nós tínhamos a condição de fazer aquilo, então nós fizemos o Parque, de dimensões boas, hoje funciona normalmente, e preservamos também a natureza. E eu também quando era Prefeito pegava o carro e saía pelo Cubatão afora ver o que estava sendo feito na defesa das matas, numa preocupação em defesa das matas, eu tinha certeza de fato de que preservando o meio ambiente, as matas e os rios, e eu fiz isto constantemente durante o meu governo e acho que fui bem sucedido."

Possivelmente se repete o citado na pergunta anterior, à respeito da possível falta de uma visão mais abrangente da questão ambiental. Um fato interessante é que na gestão de "Zeca Padeiro", por exemplo, a questão da destinação adequada de resíduos sólidos domésticos não foi considerada, tendo o aterro controlado se transformado num lixão à céu aberto, sem cuidados mínimos como o espalhamento do material, compactação e cobertura com sub-solo, bem como a captação e recirculação do líquido proveniente da 
decomposição da parte orgânica, o "chorume", entre outras questões, conforme depoimento de funcionários responsáveis pelo setor no início da administração 1993/96.

Questões específicas - relação com o Grupo Ecológico Cascata Branca

O Grupo e sua principal reivindação - a proposta de implantação de um Parque na área da Cachoeira

"Zeca" demostrou ter uma visão de que, apesar dos aspectos históricos, ambientais e paisagísticos, a área da cachoeria na sua opinião não justificava tanto entusiasmo nem uma atuação mais abrangente por parte do poder público na época:

"Você foi um dos líderes, e a Laura também, mas eu achava que no meu ponto de vista particular que a cachoeira não tinha aquela expressão que devia ter. Eu ia na cachoeira. O campo de futebol eu melhorei, eu aumentei junto à cachoeira, plantei árvores na beirada do campo e na beira do rio, fiz também lá quadras para a juventude da Chave, fiz uma quadra de futebol, fiz o que pude dentro das possibilidades dentro da área da cachoeira. Mas eu sempre, modéstia a parte e você me desculpe, eu sempre achei a cachoeira uma coisa imprevisível, uma coisa que hoje você via cheia de água e depois seco, completamente sem água, perdeu aquela visão de bela cachoeira, você não lembra, era menino, mas havia mais água, havia mais condições, então eu não via com muito entusiasmo, daí uma das razões, você ficou magoado comigo, eu sei disso, a Laura também, mas eu não via nisso aquela condição de ser dar ênfase, mas eu fiz o que pude".

Essa sua visão não foi colocada de forma explicita na época, e também provavelmente nem o poderia tendo em vista que havia um certo grau de colaboração entre a Prefeitura e o Grupo Ecológico no que se refere a questões pontuais como 
realização de eventos e outros, nunca havendo uma atitude extrema por parte do Prefeito que possibilitasse o aprofundamento de críticas do Grupo em um nível maior que o ocorrido, uma vez que o Grupo contava com o relativo apoio da imprensa local e regional.

Quando questionado sobre o fato da Prefeitura não ter participado da série de reuniões onde estiveram presentes representantes de várias entidades como Grupo Votorantim, DEPRN, CETESB, Associações de moradores, professores da USP e outros, também a explicação de 'Zeca" foi baseado na sua opinião sobre a área objeto da mobilização:

"(...) eu achava que a cachoeira não tinha aquela importância que o Grupo dava, e de fato não tem, eu sempre achei aquela cachoeira até uma coisa anormal, porque uma cachoeira como Paulo Afonso...mas aquela cachoeira da Chave, tem dias qie ela tem água e tem dias que ela não tem água. Ela também tinha um mau-cheiro terrivel, eu tinha medo de implantar alguma coisa na cachoeira por motivos de saúde, eu fui várias vezes lá, eu sempre ia, eu notava aquele mau cheiro que exalava, que vinha da Votocel (...)",

Zeca se referiu a emissão de efluentes líquidos pela fábrica de papel celofane do Grupo Votorantim, a Votocel, situada à montante da cachoeira, que foi desativada por volta de 1996 em função da substituição do celofane pelo poliprobileno bi-orientado (P.B.O.), com nova indústria implantada vizinha àquela. Atualmente o sistema de lagoas de tratamento da Votocel foi cedido ao Serviço Autônomo de Água e Esgoto de Votorantim, o SAAE, que está adaptando as lagoas para receber e tratar aproximadamente $40 \%$ do esgoto doméstico lançado no rio Sorocaba sem tratamento.

Zeca também citou como um dos motivos, além da sua percepção de pouca importância e atratividade da área e de problemas de saúde ocasionados pela eventual poluição industrial (aparentemente se contradizendo, uma vez que o mesmo afirmou ser esse um problema do passado), a questão dos afogamentos seria também um dos motivos pelo não desenvolvimento de algo mais elaborado na área: 
"(...) fiz o que pude dentro das possibilidades, mas eu sempre tive, e inclusive sempre me manifestei pelo perigo que a cachoeira traz. Quantos já morreram naquela cachoeira, e continuam morrendo. Não tem estrutura, não tinha nada e não tem, quando a água baixa, há possibilidade menor de afogamento, mas quando ela fica mais bonita, o pessoal desconhece totalmente e acaba se afogando. São vários afogamentos, não é nem um nem dois, muitos afogamentos, e era uma das preocupações minhas como Prefeito."

Quando questionado sobre a proposta elaborada e entregue a Prefeitura em março de 91 ("Proposta de Implantação do Parque Municipal da Cachoeira de Votorantim com a Participação da População") e as cobranças para seu encaminhamento, que resultaram em um conflito registrado no imprensa, "Zeca" respondeu:

"Eu, falando com franqueza, não me lembro desse projeto. Não me lembro nada que tivesse lido com relação à vocês. Mas eu sempre fiz que pude dentro das possibilidades da Prefeitura (...) mas ocorre que ainda sempre há aquele vsetígio de perigo. Eu acho que ainda hoje é perigosa a cachoeira da Chave, com relação à segurança principalmente dos menores, esses dias morreu gente lá, então, naturalmente não foi por esse motivo que eu não cheguei até vocês, eu acho que não chegou até as minhas mãos, então ficou na mão de um de meus assessores, como disse a você não dá para controlar $100 \%$, você pode controlar $99 \%$ e o resto cargos de confiança, pode ter havido um falha, mas não me lembro desse pormenor."

Lembrando que a área da Cachoeira foi desapropriada do Grupo Votorantim no final de 91 em sua gestão, ao ser questionado sobre uma eventual influência da pressão do Grupo Ecológico, "Zeca" respondeu que "teve uma certa relação", passando a enumerar os beneficios de tal desapropriação que também envolveu áreas contíguas e que isso deu mais esperança para que se fizesse algo: 
"(...) então nós desapropriamos, então isso deu ênfase mais ainda para que se fizesse alguma coisa(...)", finalizando com a recomendação para que o autor buscasse junto ao Prefeito atual condições de melhoria para a área.

Foi questionado também sobre se "Zeca" se lembrava da idéia do Grupo Ecológico de se criar uma Fundação para viabilizar a implantação do Parque, idéia esta que foi adotado por um ex-assessor do Prefeito e divulgado na imprensa, Sr. Celso de Oliveira Campos:

"Não, aliás eu tinha pouco contato com o Celso, que fazia parte do setor jurídico, mas me lembro do fato, se saiu na imprensa não me recordo mais, mas eu nunca me opus a que fizessa algo que beneficiasse a Chave $(\ldots)$ ".

Outras questões de interesse - relação Prefeitura e Grupo Ecológico

A questão a seguir necessita de alguns esclarecimentos prévios. $O$ autor apresenta um distante grau de parentesco com o ex-prefeito Erinaldo Alves da Silva, sendo este último filho de um primo de seu avô paterno, migrante nordestino que mudou-se para Votorantim na década de 40 atraído pela oportunidade de emprego na fábrica de cimento Votoran, situado no bairro Santa Helena. O pai do autor também havia ocupado o cargo de Diretor de Serviços Públicos no final da gestão 83/88 de Erinaldo Alves da Silva, portanto ocupado um cargo-chave na administração de um adversário político. Apesar desse distante grau de parentesco, existia essa associação do autor como "sobrinho" de um então adversário político do grupo do Prefeito "Zeca Padeiro", e dentro das peculiaridades da vida política local, existiam indicativos de que esse fator pesava dentro das relações entre a ONG "Cascata Branca" e a administração. A pergunta foi: "O Grupo Ecológico tinha como um dos líderes eu e a Laura Jane, e pelo fato de eu ser parente distante do Erinaldo, um adversário político seu, isso chegou a afetar, as iniciativas do Grupo tiveram dificuldades em relação a esses fatos ou não?"'. "Zeca" respondeu: 
" Em parte sim, não vou negar a você porque "a política era a política", e tudo aquilo que se faz em relação à política, e houve, mas eu não olhava por esse ângulo, olhava Votorantim e a Chave naturalmente, apesar de que eu sabia que você era sobrinho de um adversário político naquela época, hoje grande amigo meu, mas na época era inimigo político meu, adversário - pois não tenho inimigos, tenho adversário, e a Laura também, coitadinha, e quando você tem alguma coisa em relação a outras pessoas há uma dificuldade, há uma dificuldade, mas por mais boa vontade que você tenha mas estou com minha consciência tranquila".

Quando novamente questionado se teria havido alguma resistência por parte de seus assessores, "Zeca" respondeu:

"Não, não tenho conhecimento dessas coisas, absolutamente, eu tratava direto com vocês assim como eu tratava direto com os munícipes, com relação a isso podem ficar tranquilos que não houve nada, nada que obscurecesse..."

Teve seqüência então um diálogo do ex-prefeito com o autor-entrevistador aqui transcrito: (Adriano): "Mas que existiu essa influência, isso existiu..."("Zeca"): "Houve uma certa influência devido ao fator político, você sabe que o fator político está..." (Adriano): "...acima de tudo...("Zeca"): "desliga isso aí, está desligado? ..." referindo-se ao registro da conversa que estava sendo feito e foi interrompido pelo autor a pedido do entrevistado, devido ao conteúdo "político" da entrevista segundo o mesmo.

Essa questão remete a necessidade de discussão mais aprofundada sobre as peculiaridades das relações entre o poder público e entidades da sociedade civil, que no caso de um município de médio porte (quase 100.000 habitantes) como Votorantim, em plena efervescência da questão ambiental na época trazida pelo fato do Brasil estar se preparando para organizar o maior evento do planeta, a "ECO 92" (Conferência das Nações Unidas sobre Ambiente e Desenvolvimento"), ponderou-se a iniciativa de um grupo de estudantes inclusive pelo grau de parentesco de um dos líderes com um adversário político e suas implicações "políticas" , que exerceu uma influência difícil de 
ser mensurada mas provavelmente forte, comprovado pelas dificuldades práticas encontradas.

Outros fatores merecem ser destacados, como a falta de um interlocutor dentro da Prefeitura na época como um técnico da área ou mesmo algum funcionário mais interessado na questão ambiental, aliado a falta de um órgão específico para o tratamento dos assuntos voltados ao meio ambiente.

A princípio existiu um certo "provincianismo" na leitura que o poder público fazia da iniciativa do Grupo, baseado em associações com grupos políticos adversários, uma visão limitada e pouco profunda da questão ambiental e sua complexidade e a pouca experiência do poder público na relação com organizações da sociedade civil. Geralmente, as relações ficam restritas por parte de Associações de Moradores (pouco organizadas) que fazem reivindicações voltadas para a busca de solução de problemas pontuais, como falta de asfalto, iluminação pública e outros, caracterizada pelo paternalismo e pouco questionamento acerca de problemas mais gerais.

Essa falta de clareza possivelmente expressou-se na resposta dada pelo exprefeito sobre questões mais amplas, como a existência de uma relação entre política e meio ambiente e o descompasso entre a Legislação avançada (municipal inclusive) na área ambiental e a realidade da estrutura da Prefeitura e do município. Ao ser questionado sobre a relação entre política e meio ambiente, limitou-se a afirmar:

"A política procura o melhor, nós políticos procuramos melhorar o ambiente, o meio ambiente (...)" passando então a citar a sua iniciativa em implantar o parque do Matão e o fato de Votorantim ser uma das cidades "menos poluídas, não só do Estado de São Paulo", bem como enfatizar o trabalho dos outros prefeitos na luta por uma cidade melhor.

Em relação ao descompasso entre a Legislação e a realidade, após um questionamento onde o autor citou como exemplo a Lei Orgânica que possui um capítulo específico relativo ao meio ambiente, mas que não foi colocado em prática, "Zeca" explica essa situação pela sua opinião de que Votorantim não tinha problemas ambientais significativos e falta de recursos específicos, bem como apoio governamental: 
"De fato, infelizmente, muita coisa fica só no papel, e quase nada se faz. O caso aí da Lei Orgânica, foi estudada pelos vereadores, houve alguma coisa em função disso mas não se formou nenhum gabinete, alguma coisa em função dessa Lei. Mas vou dizer com toda certeza para você, com toda segurança: nós talvez não tivéssemos tomado essa atitude, já não lembro, são doze anos já, dez anos, em relação a isso porque Votorantim sempre teve um meio ambiente bom, apesar das dificuldades que nós passamos com a poluição do cimento e da Votocel, mas o nosso ar era puro, era bom, nossa condição também era boa geograficamente, então eu acho que não houve interesse por causa disso e talvez também por falta de recursos, porque era fácil você colocar no papel uma Lei mas tem que trazer recursos para que isso aconteça, e inclusive o próprio governo estadual nunca nos deu satisfação sobre isso, nunca chegou um assessor de um deputado, do meio ambiente, fazer alguma coisa. O que eu fiz na cachoeira, alguma coisa em relação a benefícios, que são poucos e eu reconheço foi por vontade própria minha e da Prefeitura, porque não havia recurso para isso, não havia recurso, nunca ajudaram a gente para isso. Então essa falha maior não é do Prefeito, é do Governo Estadual e Federal, que tinha essa obrigação também."

De fato, a interpretação do ex-Prefeito de que Votorantim não tinha problemas ambientais significativos, assim como a área da cachoeira não tinha atributos que justificassem uma ação mais ampla e em parceria com outros órgãos e entidades bem como a falta de recursos certamente atuaram de forma conjunta, aliado ao "problema político" advindo do distante grau de parentesco do autor com um ex-adversário político, de certa forma contribuíram para a inviabilização do início de um trabalho mais amplo voltado à questão ambiental.

A falta de um órgão e mesmo um técnico na Prefeitura na área ambiental também pode ter contribuído para essa dificuldade de relacionamento, assim como posturas de 
críticas contundentes dos integrantes do Grupo em relação à omissão da Prefeitura, cujo anseio por atitudes e medidas concretas e rápidas não encontrou eco dentro da estrutura hierarquizada de poder existente.

Entrevista com Erinaldo Alves da Silva

Trajetória política

Assim como 'Zeca", Erinaldo destaca seu envolvimento na luta pela emancipação político-administrativa de Votorantim e a influência de um amigo que o motivaram para a vida política:

"Eu sempre gostei de política, participei da campanha da emancipação, quando, após a emancipação, a sociedade começou a se mobilizar para participar de partidos políticos".

Não conseguiu participar da primeira eleição, saindo candidato a vice-prefeito na segunda eleição pelo MDB tendo como candidato a Prefeito Luiz do Patrocínio Fernandes:

"Me filiei ao MDB, e quando chegou em 1968, no período em que estavam escolhendo os candidatos lembraram do meu nome e do Luiz do Patrocínio que era o candidato a Prefeito, presidente do Sindicato dos Têxteis, me procuraram e me convidaram a ser candidato a vice-prefeito. Eu aceitei e aí começou o meu trabalho na vida pública ".

Erinaldo ocupou a Chefia de Gabinete, único cargo de confiança na época e na linha de frente da administração.

Erinaldo então participou da próxima eleição (72), sendo eleito prefeito na gestão $73 / 76$, , novamente eleito prefeito para o período $83 / 88$ e por último na gestão $93 / 96$, esta última coincidindo com as últimas atividades do Grupo Ecológico e com o ingresso do autor nos quadros técnicos da Prefeitura. Saiu também candidato a Deputado Estadual na década de 70 e novamente na eleição de 96 , não conseguindo se eleger. 
Principais realizações das administrações

Erinaldo teve grande participação na estruturação do município, acompanhando desde praticamente sua instalação até os dias atuais e com uma visão clara sobre os problemas enfrentados prioritariamente, citando o abandono do então distrito em relação à sede, Sorocaba:

"Nós pegamos uma cidade praticamente começando. Os problemas eram muitos, um dos motivos pelos quais a cidade se emancipou foi exatamente $o$ abandono que $o$ distrito vivia em relação à Sorocaba. Então problema de água, problema de escola, problema de urbanização, problema de saúde, todo tipo de problema o município vivia."

Destacou a existência de um Plano Diretor elaborado na gestão anterior e a ênfase dada a Educação, com a construção de novas escolas. Segundo Erinaldo, os problemas se avolumaram com o crescimento da cidade, que superara todas as expectativas projetadas, principalmente na área de saúde, saneamento básico e educação:

" Claro que houve um planejamento, e dentro desse planejamento previa-se para Votorantim 30 mil habitantes na década de 90. Chegamos na década de 90 com 70, 80 mil habitantes, então evidentemente esse planejamento precisou ser refeito".

Entre os principais desafios vencidos, Erinaldo destaca a construção de escolas em todos os bairros, o programa de Creches iniciado na sua segunda administração assim como o Programa de Saúde também iniciado na sua segunda gestão, onde previuse a construção de Centros de Saúde em todos os grandes bairros, com atendimento primário à população principalmente gestantes, crianças e carentes e que está sendo finalizado com a construção do Pronto Atendimento e Hospital (este último com previsão de término para o segundo semestre do ano 2000). Destacou também na área de urbanização uma infra-estrutura pronta, com rede de água, esgoto, iluminação e pavimentação. 
Em relação aos problemas que a cidade enfrenta, Erinaldo fez uma análise crítica em relação ao emprego:

" $\mathrm{Na}$ área de emprego na realidade nós tivemos um retrocesso. $\mathrm{O}$ município se emancipou e ele abrigava populações vizinhas que vinham atrás do emprego, particularmente de Sorocaba. A modernização tecnológica acabou gerando um processo inverso. A fábrica de tecidos que chegou a gerar 6.000 empregos hoje tem 400,500 empregados. A Metidieri, eu trabalhava lá e quando eu saí tinha 1.300 funcionários e hoje tem 200. E quando você contar com a fábrica de cimento, a fábrica de papel, então hoje o grande marcado de trabalho que surgiu com a emancipação é hoje o poder público, que abriga hoje quase 2.000 pessoas, mas que não é suficiente para cobrir o que a cidade perdeu com o avanço tecnológico. Então hoje a cidade vive um processo até certo ponto estagnado de crescimento, um processo mais parado de crescimento, exatamente porque a cidade não comporta mais gente, não adianta muita gente vir para cá porque hoje não tem mais emprego".

Erinaldo destacou também o plano de moradia elaborado na sua gestão e que atualmente está sendo posto em prática através de loteamentos populares, estando três loteamentos em fase de ocupação e um em fase inicial de implantação, assim como o fato da legislação rigorosa de parcelamento de solo que de certa forma contribuiu para o não agravamento dos problemas ocasionados pelo crescimento urbano.

Existência de problemas ambientais em Votorantim

Ao contrário de "Zeca", Erinaldo reconheceu a existência e gravidade dos problemas ambientais:

"Votorantim à exemplo da maioria das cidades tem problemas ambientais sim. Votorantim continua lançando seu esgoto bruto nas 
águas do rio Sorocaba e córregos, nós temos o problema do lixo (...) Há a necessidade de uma política ambiental mais rigorosa e até a conscientização da população no que diz respeito a preservação das áreas verdes, de limpeza, de uma série de coisas que acho que é muito importante para a cidade ".

Erinaldo também citou avanços relativos ao controle da poluição ambiental das indústrias por parte do Governo, afirmando que esses problemas mais graves foram solucionados. Citou que já estão sendo tomadas as providências para a despoluição do rio Sorocaba (aproveitamento do sistema de tratamantos de efluentes da fábrica desativada Votocel para tratar $40 \%$ do esgoto doméstico lançado no rio, em fase de implantação) e da busca de solução para o lixo, destacando a possibilidade de um processo seletivo ou usina de compostagem. Finaliza afirmando em relação aos problemas ambientais:

"Mas a cidade tem e vai combater isso com uma política, com uma legislação municipal também e com a conscientização da população."

\section{Atividade do Grupo Ecológico Cascata Branca}

A época de maior atuação coincidiu com a gestão do Prefeito "Zeca Padeiro". Ao ser questionado sobre a lembrança de algumas idéias e atividades do Grupo, Erinaldo destacou a cobertura da imprensa e o caráter de pioneirismo da iniciativa:

"Acho que na realidade aquilo foi uma semente, que deixou na realidade deixou uma herança, que não era uma idéia específica de vocês, mas uma idéia que vinha sendo defendida no mundo inteiro e que em Votorantim vocês levantaram uma bandeira que muitos hoje estão seguindo. Talvez não tanto com a mesma intensidade de vocês, pois vocês foram pioneiros e entraram fundo e tiveram um bom espaço na imprensa, mas acho que hoje a gente já pode sentir 
vários outros grupos pequenos, atuando de forma mais tímida mas atuando. Acho que aquilo na realidade foi um pontapé inicial, um trabalho de base, e que sabe no futuro vai acabar recebendo o reconhecimento porque nas escolas, com freqüência você sente algumas movimentações, alguns trabalhos que fazem lembrar exatamente o início do trabalho de vocês".

Possivelmente Erinaldo ao se referir a outros grupos atuando tenha se referido a outras localidades, pois em Votorantim não tivemos registro de nenhuma outra entidade ambientalista atuando de forma mais consistente e organizada após a desativação do Grupo Ecológico Cascata Branca, em 1993. O que merece destaque é a percepção de um "provável reconhecimento futuro" e não presente dos resultados da ação ambientalista, como se essas reivindicações e lutas não se relacionassem com questões cotidianas e problemas reais existentes.

Como já citado, uma das últimas atividades de maior impacto realizada pelo Grupo Ecológico foi a participação em um Debate entre os candidatos a Prefeito em setembro de 92, do qual Erinaldo participou, onde solicitou-se dos mesmos assumir compromissos relativos a propostas básicas na área ambiental, em âmbito geral e específicas em relação a proposta participativa de implantação do Parque Municipal da Cachoeira. Erinaldo foi o único candidato a se recusar a assinar e se comprometer com aquelas reivindicações colocadas na forma de um documento. Ao ser questionado sobre aquele evento, não citando maiores detalhes, respondeu:

"Me lembro sim, me lembro perfeitamente que durante o debate foi questionado sobre os candidatos sobre a necessidade, era um trabalho que o Grupo vinha fazendo sobre a preservação da área da Cachoeira, como praticamente um local que a cidade tinha e de suma importância e que precisava ser preservado. Na oportunidade fui questionado se os Prefeitos priorizariam a cachoeira, a preservação da cachoeira, ou desenvolveriam alguma coisa que garantisse a cachoeira da Chave como um local de preservação ecológica. Eu me lembro que naquela oportunidade não quis 
assumir de público um compromisso, mas assumi comigo pessoalmente um compromisso, pois sabia da importância da cachoeira, dabia e sei, são poucos os municípios que tem o privilégio de ter praticamente no coração, no centro de sua cidade uma cachoeria como nós temos."

Erinaldo citou então que embora não assumindo o compromisso recebeu um relatório (cópia do projeto "Proposta de Implantação do Parque Municipal da Cachoeira de Votorantim com Participação da População") de integrantes do Grupo Ecológico no começo de sua gestão, e destacou o fato de ter elaborado o projeto do Parque da Cachoeira (contratado uma empresa especializada na área de arquitetura e paisagismo) durante a gestão 93/96:

"(...) ditamos as coordenadas que deveriam nortear o projeto, e esse projeto já existe, claro que para até ser colocando em prática leva algum tempo, mas sejam quem for os administradores que venham acho que devem levar em conta isso porque a gente não faz um projeto para o momento Prefeito. $\mathrm{O}$ desafio da preservação da área da cachoeira continua, e acho que seja quem for o Prefeito, independente de partido político, e hoje a política de preservação da natureza não tem partido, é uma política que tem que estar na mente de todas as pessoas que são responsáveis dentro da sociedade".

Citou que não foi possivel desapropriar a área, mas a mesma já fora desapropriada desde 91, na gestão anterior (o projeto foi contratado em 95 ). $\mathrm{Na}$ concepção de Erinaldo enquanto administrador, a elaboração do projeto sem compromisso para sua execução imediata se justifica enquanto elaboração de diretrizes para a ocupação da área. Essa concepção porém contrariou a visão de ex-integrantes do Grupo como visto, inclusive com críticas contundentes na imprensa, basicamente pelo motivo que a proposta do Grupo era voltada à criação de um envolvimento da população dentro de um processo educativo e participativo de concepção e implantação de um 
espaço livre de uso público, enquanto que a visão da administração era de um projeto arquitetônico e paisagístico convencional, sem caráter educativo.

Questionado sobre uma proposta feita pelo CEPAM, órgão da Fundação Prefeito Faria Lima, que desenvolveu uma proposta de ocupação da área da cachoeira durante a gestão 83/88, Erinaldo destacou a importância da continuidade administrativa, citando o caso da Praça de Eventos, localizada em região central, cujo esboço foi feito na gestão $83 / 88$, mas só foi implantada na gestão 93/96. Porém cita que na época dessa segunda gestão outras prioridades impediram a viabilização de alguma proposta na área da cachoeira e na área ambiental:

"Mas nós tinhamos alguns desafios sérios durante a segunda gestão, e ainda hoje a gente houve algumas críticas quando se fala que Votorantim é um município que tem um potencial enorme turístico, que a cidade poderia desenvolver um projeto mais detalhado. Eu também concordo que Votorantim tem vários pontos turísticos, alguns locais de beleza natural, que a gente poderia desenvolver alguma coisa. Só que é dificil viver num momento que nós vivemos quando nós tínhamos um número elevado de mortalidade infantil causado por doenças de veiculação hídrica, motivado pela má qualidade da água. Eu levei a minha segunda administração inteira praticamente para construir a estação de tratamento de água, que era fundamental para a saúde da população. "

Erinaldo destacou como iniciativa da sua segunda administração a criação do Conselho Municipal de Defesa do Meio Ambiente, o COMDEMA:

"(...) eu cheguei na minha segunda gestão a ter o COMDEMA por uma temporada, foram algumas iniciativas tímidas, mas isso já demonstrava a nossa preocupação."

O que merece citação é que na sua terceira gestão (93/96), desde o momento no qual o autor passa a integrar os quadros da administração tentou por seguidas vezes através de oficios e processos internos revisar e implantar o COMDEMA, sem qualquer 
retorno por parte da administração, seja na discussão, seja na sua efetiva implantação, e até o presente momento o referido conselho não foi criado.

O que desponta desse depoimento é a lógica das prioridades na administração dos problemas municipais, onde sempre necessidades emergenciais não permitiram que fosse dada atenção às questões ambientais, e o fato de que atualmente Votorantim pode começar a pensar e agir no assunto, pois a fase crítica de estruturação foi relativamente vencida:

"(...) e hoje, no estado que a cidade chegou não tenho dúvida, hoje já se pode com toda a certeza se desenvolver um projeto pé-nochão, um projeto novo, amplo, envolvendo toda a sociedade, e fazer de Votorantim, quem sabe até implantar em Votorantim no caso um projeto, se não modelo, um projeto bem moderno voltado para a preservação da natureza."

Em janeiro de 1993, o autor inicia a carreira de Pesquisador Científico do Instituto de Botânica da Secretaria de Estado de Meio Ambiente, através de concurso público ocorrido no ano de 92, sediado no Jardim Botânico de São Paulo. Nessa época o Grupo Ecológica ainda tinha algumas atividades internas nas escolas, mas sem a mesma intensidade e envolvimento anterior.

Como fruto de seu envolvimento, o autor elaborou tanto uma proposta de Curso de Capacitação para os integrantes do Grupo quanto uma proposta de parceria entre o Instituto de Botânica e a Prefeitura, logicamente tendo como ênfase a realização de um trabalho na área da cachoeira. Quando questionado sobre essa proposta, Erinaldo respondeu dizendo:

"me recordo sim, e nós passamos evidentemente a sua proposta para a Secretaria de Obras que na época deveria ser o responsável por toda essa área de manutenção, responsável por essa área de preservação da Prefeitura. Na época você me entregou aquela proposta, nós passamos para o Abibe (Secretário de Obras), e nós pedimos que ele verificasse e se não me engano chegou-se até a 
trazer algumas mudas, algumas coisas, mas a coisa não prosperou, não foi para frente (...)".

De fato, tal proposta não teve qualquer tipo de retorno por parte da Prefeitura. Erinaldo cita como exemplo também uma proposta de implantação de coleta seletiva esboçada pelo Secretário de Obras que também não avançou, e termina afirmando que "(...) o que importa na realidade, que a gente tem sentido que de uma forma geral o problema ambiental deixou de ser ima coisa de segundo plano, de terceiro ou quarto plano, e tem sido hoje visto com bastante responsabilidade pelos governantes e pela sociedade. Acho que algumas tentativas não deram resultado esperado, e de uma forma geral a gente sente que a coisa hoje começa a tomar uma conotação mais séria, de mais responsabilidade".

O início do trabalho do autor na Prefeitura

Em agosto de 93 o autor recebeu o convite do Prefeito para assumir um cargo na Prefeitura, após os contatos feitos ainda como Pesquisador do Instituto de Botânica. Uma série de fatores foi o responsável pela decisão em aceitar o convite, entre os quais o fato do autor estar trabalhando em São Paulo, mas morando em Votorantim, com grandes despesas de transporte e desgaste, o baixo salário do Estado na época, inclusive com a mobilização e paralisação das categorias dos Institutos de Pesquisa por equiparação salarial com os docentes das Universidades Públicas (só conseguido no ano de 1999) e a esperança do autor em finalmente poder colocar em prática suas propostas da época do Grupo Ecológico, entre outros fatores.

O cargo ocupado foi o de "Chefe de Seção de Controle e Uso do Solo", ligado a princípio à Secretaria e Diretoria de Obras, cargo de terceiro escalão dentro da hierarquia municipal. Na época também o então vereador A., colaborador do Grupo Ecológico e que naquele momento havia saído do partido que fora eleito (PT) e ingressado no partido de situação (PSDB) também realizou uma relativa pressão para a vinda. Somente a partir de fevereiro de 95 o autor passou a fazer parte do quadro de funcionários efetivos da 
Prefeitura, após da criação do cargo de Engenheiro Florestal e realização de concurso público.

Posto isso, a pergunta formulada abordou claramente sobre a eventual existência de uma pressão do então vereador A . para a contratação do autor, o que foi respondido:

"acho que independente de pressão, e quero que você saiba que existe um vínculo de parentesco, e evidentemente nós chegamos em um ponto de entender que nós deveríamos fazer um trabalho na área de preservação ecológica, e que nós tínhamos em Votorantim um técnico formado capaz de ajudar, claro que isso pesou. Pesou o grau de parentesco, pesou sua situação pessoal em Votorantim e pesou também na época o trabalho, a interferência do Alemão intercedendo também"

Observamos que um conjunto de fatores levou a decisão da contratação que não só as questões das propostas e interesse em desenvolver projetos na área ambiental, entre eles inclusive o grau de parentesco, lembrando ainda que o pai do autor havia sido Secretário de Serviços Públicos nos últimos anos da sua segunda gestão (83/88).

A partir desse ponto, Erinaldo cita as dificuldades da administração que segundo ele contribuíram para que não fosse posta em prática uma atuação mais ampla da Prefeitura em relação à questão ambiental, entre eles a complexidade dos problemas cotidianos da Prefeitura, o fato de que o autor nunca ocupou um cargo de "linha-defrente", sempre subordinado a diretores e secretários (sem formação específica nem conhecimento na área ambiental, alguns leigos e Engenheiros Civis, por exemplo) e "outros interesses da administração".

Destacou também no seu ponto de vista os avanços que teriam ocorrido com o início do trabalho:

" (...) eu acho que iniciou-se um processo de arborização da cidade, vários casos de ajardinamento, plantação de árvores ao longo do rio, toda incumbência que nós precisamos para solucionar problemas ligados aos órgãos que cuidam da preservação 
ambiental, onde você sempre se fez presente, acho que tudo isso justificou".

Erinaldo ressaltou novamente o envolvimento profundo do autor com a questão ambiental e a validade daquele movimento feito na época do Grupo Ecológico:

"E mais do que isso, saber que você tem uma idéia, que você persegue uma idéia, que embora envolvido com os problemas de rotina, do dia-a-dia da Prefeitura, você não abdicou daquilo que é sua razão principal inclusive de ter entrado na Prefeitura, e há de continuar batalhando por uma política de preservação ambiental em Votorantim, eu acho que isso é importante. Se você ainda não viu o resultado disso e está sentindo o peso dos anos, não quer dizer que a coisa morreu. Pode ter certeza que o grande mérito de vocês no início da década de 90 que sabe vocês vão colher daqui a 10,15 , 20 anos, que houve uma consciência coletiva da coisa, que aquilo que vocês queriam demorou mas chegou (...)".

O entrevistado novamente ressaltou a questão da priorização dos problemas, que não permitiram uma atenção para os problemas ambientais na fase inicial de estruturação do município, mas que agora seria possivel:

" Mas de qualquer forma eu acho que no estágio que Votorantim chegou, eu falo isso em todos os lugares que eu vou, nós hoje já podemos com os pés no chão planejar algumas coisas com a certeza de que nós não vamos sacrificar nenhum setor vital da sociedade".

Um momento bastante importante da entrevista foi o questionamento a respeito da crítica contundente (artigo "A história se repete") feito por uma ex-integrante do Grupo Ecológico a respeito da contratação de um empresa particular para a elaboração de um projeto para a área da cachoeira e que não iria executá-lo. Erinaldo citou que a sua administração passava por um período conturbado e que por trás disso haviam "interesses políticos", destacando que era normal que se quisesse a participação e situação: 
"Num primeiro momento, criticaram porque não existia projeto depois criticaram porque existia um projeto (...) claro, se batalhou por aquilo e se queria ter participação".

$\mathrm{Na}$ visão de Erinaldo o projeto elaborado pela empresa particular era abrangente e contemplava os aspectos de preservação necessários, e que o fato de não poder executá-lo no momento não era novidade, sendo que a maioria dos projetos governamentais não são postos em prática por aqueles que o elaboram, sendo então um projeto para o futuro: "(..) eu vou me dar feliz se daqui a 20 anos nós tivermos esse projeto concluído (...)".

Destaca que medidas como recuperação da vegetação das encostas, a retirada do sistema de esgoto que seriam mais importantes que o início da obra em si. Foi veemente na defesa da transparência do processo de licitação para escolha da empresa que elaborou o projeto, destacando que nunca conseguiram provar nenhum ato irregular de sua administração, numa referência ao grupo de vereadores de oposição que denunciaram o caso na justiça. Finaliza essa fase da entrevista como a colocação que sintetiza sua opinião:

"deixei para a região da cachoeira um projeto, e peço que Deus me dê vida para ver esse projeto executado, e aí que sabe o pessoal vai entender que não foi do jeito que eles quiseram mas eu não fiquei alheio, não dei costas ao problema"

Erinaldo se referiu a crítica pela forma como tal projeto foi encaminhado, desconsiderando-se a proposta elaborada pelo Grupo Ecológico de um diagnósitco prévio tendo como elemento principal a oportunidade de desenvolver um trabalho de educação ambiental com base na participação popular.

Não caberia aqui a proceder um julgamento de valor, mas a concepção de Erinaldo de desenvolvimento de um projeto de implantação de uma área verde como o da cachoeira, é a concepção típica de uma obra como outra qualquer, que envolveria a elaboração de edital de concorrência pública para empresas especializadas, sendo coordenadoe centralizado pela Secretaria de Obras. Esse é o normalmente o procedimento de rotina de toda administração pública em relação a obras desse tipo. 
Quando abordado sobre o conhecimento de outras iniciativas de intervenção na área da cachoeira por moradores, Erinaldo citou os problemas ocasionados pela implantação de um local de venda de bebidas na área, sem qualquer infra-estrutura, na tentativa de melhorar as condições do local motivado pela forte atratividade principalmente no período do verão, e a necessidade de intervenção da Prefeitura para acabar com aquela situação. Propôs até o isolamento da área por questões de segurança dos freqüentadores e de forma a evitar a degradação, até que possa ser feito algo mais adequado por parte da Prefeitura.

Parcerias entre o Poder Público e Entidades não-governamentais

Erinaldo respondeu afirmativamente a questão da possibilidade de parcerias entre o poder público e a Prefeitura em relação a área ambiental, após novamente ressaltar a questão das prioridades:

" (...) nós temos algumas coisas que são verdadeiros desafios. Até hoje o poder público, tenho dito a você, o município de Votorantim sempre teve prioridades que se impuseram como necessidades emergenciais, e fizeram com que a Prefeitura não tivesse destinado ao problema ambiental uma atenção maior. Nós atingimos um estágio hoje que a cidade pode pensar em algumas coisas que no passado ela deixou passar despercebido"

Citou o potencial turístico da cidade e a possibilidade do município hoje poder arcar com uma infra-estrutura nessa área sem prejudicar as demais, bem como a possibilidade de um crescimento industrial mais adequado. Também ressaltou o fato da existência de uma infra-estrutura habitacional, saneamento básico e as perspectivas de desenvolvimento com a duplicação da Rodovia Raposo Tavares, que corta parte do município, concluindo sobre a possibilidade dessas parceiras desde que se defina claramente o que se quer as atribuições de cada um, exemplificando com propostas do Plano Diretor ,de empreendimentos particulares envolvendo áreas de interesse ambiental 
e de áreas potenciais para a implantação de áreas de visitação pública e de lazer para a população.

O autor lembra que durante sua administração por diversas vezes tentou viabilizar uma parceria entre a Prefeitura e o Núcleo de Atividades de Cultura e Extensão da ESALQ/USP, inclusive com minutas de termo de cooperação elaboradas, sem qualquer resposta efetiva ou encaminhamento.

Relação entre a Legislação Ambiental e situação atual

O questionamento procurou saber a opinião de Erinaldo sobre o fato de apesar da uma detalhada legislação ambiental, pouco desse Legislação ter sido posta em prática no município. A resposta começa com um questionamento amplo sobre a dicotomia entre a postura dos países ricos em relação aos pobre no que diz respeito da destruição dos recursos naturais:

" Eu acho hoje, vejo uma certa hipocrisia, países que destruíram suas florestas, destruíram suas riquezas naturais, e não tiveram nenhum escrúpulo na luta pela conquista de riquezas acabarem com a natureza. Chegam num país pobre tentando dizer como é que tem que ser feito, só que tudo diferente do que eles fizeram. Infelizmente, problema de cultura."

Essa visão é muito comum no meio político e empresarial e tem relação com o conceito de soberania do país na interpretação desses agentes, visão esta muito difundida principalmente no meio militar, indicando a complexidade e profundidade dos problemas ambientais que não respeita as fronteiras dos países e a evolução da sociedade global na percepção sobre as causas e conseqüências desses problemas.

É citado também o fato de que esse "esquecimento" em relação ao cumprimento da legislação não se restringe apenas a legislação ambiental, mas um fato comum em nosso país, e que uma "cultura imediatista" de se fazer as coisas pela necessidade seriam as responsáveis pela não aplicação dessas Leis, além do fato de uma "imposição" de 
outras esferas de Governo que condicionavam a aprovação de projetos de interesse da administração com a existência dessas Leis.

Erinaldo finaliza com uma visão de futuro de que a própria tomada de consciência por parte da população é que garantirá a melhoria das condições ambientais:

"(...) eu acho que bem ou mal hoje não é a consciência que se esperava mas é muito mais que foi no passado, essa consciência vai prevalescer, da necessidade de se preservar a natureza, e quem sabe nessa hora se chegue a conclusão que essa legislação não seja necessária, e você partir para uma legislação melhor. De qualquer forma, eu acho que nós já estamos dando alguns passos. Votorantim no entanto tem que tirar o esgoto das águas do rio, temos que partir para um processo de dar um destino final para o lixo, ou até mesmo um processo seletivo reaproveitando aquilo que é jogado fora, um plano de arborização para a cidade, a preservação das margens dos rios, na hora que se zelar pelo desmatamento, acabar com esses focos de erosão localizada que tem ficado ao "Deus-dará" como tem acontecido, já acabou com o lançamento de produtos químicos nas águas pelas indústrias, então acho que já está caminhando, vai chegar uma hora pelo menos no que diz respeito a preservação da natureza talvez nem precise de legislação, porque o homem vai ficar consciente disso."

\subsection{Ambientalismo, Poder Local e a Questão Ambiental}

Um fato interessante em relação ao ambientalismo é que segundo McComick (1992), o primeiro grupo ambientalista privado no mundo foi a Commons, Opens Spaces and Footpaths Preservation Society, fundada em 1865 na Inglaterra, tendo promovido campanhas de sucesso pela preservação de espaços para amenidades, particularmente áreas verdes urbanas, sendo uma tentativa de reação contra as 
precárias situações de vida das cidades industriais. Este seria o terceiro impulso importante do ambientalismo britânico segundo McCormick (1992), ao lado do impulso naturalista de proteção da vida selvagem e das cruzadas contra as crueldades contra os animais.

McCormick (1992) coloca a publicação do livro "Primavera Silenciosa" de Rachel Carson em 1962 como propulsor da revolução ambientalista americana dos anos 70, chamado de Novo Ambientalismo pelo autor. Segundo o mesmo, no início dos anos 70 "havia uma insistência expressiva - freqëntemente estridente - em mudanças para uma sociedade global aparentemente propensa à autodestruição" (McCormick, 1992, p.63). Esse movimento era mais dinâmico, mais sensível, tinha base mais ampla e ganhou muito mais apoio público.

Viola (1992), em uma análise sobre o movimento ambientalista brasileiro, citou que a pesquisa sobre o movimento ambientalista tem sido feito através da sociologia e da ciência política.

Dentre as abordagens teóricas que têm sido utilizadas para a análise do ambientalismo, segundo Viola (1992):

o grupo de interesse, utilizado principalmente nos Estados Unidos, segundo o qual o ambientalismo é um grupo de interesse como qualquer outro no sistema político. A demanda de proteção ambiental teria surgido com a poluição, canalizada através de sistemas reguladores do sistema político, sem apresentar nunhum desafio, sendo que alguns dos autores desse enfoque consideravam o ambientalismo como um movimento elitista;

- ambientalismo como novo movimento social, abordagem desenvolvida principalmente na Europa Ocidental por autores neo marxistas ou ecologistas radicais.

"Segundo esse enfoque; as transformações na estrutura social (forte expansão do setor serviços que absorve mão-de-obra altamente qualificada) têm favorecido a emergência de novos movimentos sociais (basicamente pacifismo, feminismo e 
ecologismo) que questionam o sistema capitalista partindo de uma orientação valorativa diferente dos movimentos sociais tradicionais, com ênfase na qualidade de vida e na descentralização" (Viola, 1992, p. 51)

ambientalismo como movimento histórico, que parte da contextualização da insustentabilidade da civilização atual, devido ao crescimento populacional, depleção da base de recursos naturais, sistemas produtivos que utilizam tecnologias poluentes e de baixa eficiência energética e sistema de valores que propicia a expansão ilimitada do consumo material (Viola, 1992).

Segundo esse último enfoque, adotado por Viola (1992) em seu artigo sobre a história do movimento ambientalista brasileiro, dentro desse contexto historicamente o setor mais educado da população começa a demandar qualidade de vida ao invés da expansão ilimitada do consumo de bens materiais, uma vez que a satisfação de suas necessidades materiais básicas já estaria plenamente satisfeita. Dentro da realidade brasileira, essas necessidades básicas estão ainda longe de estarem plenamente satisfeitas, mas isso, ao contrário de desestímulo, serviu como um elemento enriquecedor do ambientalismo brasileiro que teve de se articular com os outros movimentos sociais na luta pela inserção da qualidade de vida como direito fundamental do cidadão.

Viola (1992) apresenta um histórico do movimento ambientalista brasileiro como sendo composto de duas fases: uma fundacional (1971-1986) e outra recente, voltada à institucionalização e desenvolvimento sustentável.

Nessa fase fundacional, tivemos iniciativas pioneiras como a criação da Fundação Brasileira para a Conservação da Natureza em 1958 , voltada ao conservacionismo, e a criação de AGAPAN (Associação Gaúcha de Proteção ao Ambiente Natural), encabeçada por José Lutzem Berger, com a inclusão de questões ambientais mais amplas e influência do novo ambientalismo norte-americano. Destacamos ainda a realização da Conferência de Estocolmo em 1972, com o posicionamento desenvolvimentista do governo militar e contra o reconhecimento da importância da problemática ambiental (Viola, 1992). 
Foi registrado já nessa época o surgimento de alguns grupos ambientalistas nas principais cidades do Sul-Sudeste, sendo pequenos grupos de ativistas com pouco apoio financeiro e que tinha como objetivo denunciar problemas de degradação ambiental das cidades.

Nessa época, a cidade de Votorantim vivia em sua plenitude o "milagre brasileiro" com forte expansão industrial e conseqüente poluição, principalmente com as indústrias do Grupo Votorantim (tecidos, papel e celulose, cimento). Aziz Ab'Saber em palestra proferida em Sorocaba em 1997 citou sua perplexidade com o impacto da poluição industrial em Votorantim nos anos 60 e 70, contando a história de um operário de uma fábrica do Grupo Votorantim que, ao criticar a poluição por meio de poesias e pequenas músicas anedóticas, foi perseguido e sofreu por suas manifestações.

Lutas históricas também marcaram esse periodo fundacional do ambientalismo segundo Viola (1992), entre os quais destacamos o movimento contra a construção do novo aeroporto em Caucaia do Alto, para salvar as "Sete-Quedas" no Paraná, em defesa da Amazônia e o movimento antinuclear.

Cubatão , o "Vale da Morte", no início dos anos 80 também mobilizou o ambientalismo brasileiro, transformando-se em símbolo da degradação ambiental do país, praticamente obrigando a tomada de medidas enérgicas de controle ambiental por parte do Governo (Ferreira, 1991). Isso desencadeou uma relativa sensibilização da população em relação ao problema da poluição. A luta contra o uso indiscriminado de agrotóxicos principalmente no Rio Grande do Sul também foi um elemento importante nessa fase fundacional (Viola, 1992).

Um fato interessante é que esse autor coloca que na primeira metade da década de 80 , ainda no periodo fundacional, houve uma proliferação de grupos ambientalistas na região Sul e Sudeste, estimando-se que em 1980 havia aproximadamente 40 grupos e localizados em estados como RS, SP, RJ, MG, PR, SC, e que em 1985 esse número havia crescido até chegar a aproximadamente $400 \mathrm{em} 1985$ (com pelo menos um ano de existência).

Uma colocação muito pertinente e que serve "como uma luva" para a discussão sobre as limitações de uma entidade sem estrutura como o Grupo Ecológico Cascata 
Branca, como citaram alguns ex-integrantes a despeito das limitações e problemas enfrentados é a descrição de Viola (1982) sobre essas entidades:

"Geralmente, as associações ambientalistas estão compostas de um núcleo ativo, que oscila entre três e 20 pessoas, e um vasto contingente passivo de filiados, que vai de 50 a 200 pessoas e atinge, no caso das mais extensas, mais de 1.000 pessoas. A maioria das associações vivem uma primeira fase de sua existência sem estruturação jurídica, sendo somente depois de um ou dois anos de atividade como grupos que se organizam na forma de associação jurídica. Outra característica fundamental das associações é o peso marcante que tem, na maioria delas, uma ou duas pessoas que se destacam diferenciadamente do resto dos membros em várias dimensões: tempo e energia dedicados à associação, prestígio público, autoridade na decisão do grupo, acesso aos meios de comunicação de massa, acesso às agências estatais. Nessa fase fundacional as associações estão constituídas predominantemente por pessoas de formação universitária, com uma renda acima da média brasileira, a maioria delas profissionais e uma minoria de estudantes, com um predomínio de homens sobre mulheres. Geralmente há um ou mais objetivos específicos que são o eixo da atividade de cada associação (...) os mais comuns (...) são os seguintes: uma indústria já instalada que polui ostensivamente a atmosfera ou o sistema de águas; um projeto de instalação industrial do qual suspeita-se terá um alto impacto ambiental; a preservação de uma área verde que começa a ser degradada por uma exploração particular semiclandestina ou por um uso público predatório; uma área de preservação ecológica já definida legalmente e que está sendo degradada (...); uma área urbana de valor histórico-arquitetônico que ameaça ser devorado pela especulação imobiliária. As lutas ambientalistas urbanas implicam 
um confronto com uma empresa, alguma agência estatal. (...) Geralmente, nesta fasem a eficácia das lutas ambientalistas é muito baixa em termos de ganhos precisos, mas é significativa se considerarmos a ecologização da mentalidade dos contingentes qualitativamente importantes da população (Sorrentino, 1988). A degradação ambiental não é detida e muito menos revertida, mas a percep̧̧ão da degradação aumenta na sociedade. Como correspondente a qualquer process de ação coletiva, é no transcorrer dessas lutas que vai se constituindo a identidade coletiva do movimento ambientalista" (Viola, 1992, p. 57-58)

Entre os pontos convergentes e divergentes dessa descrição e o Grupo Ecológico Cascata Branca, citamos:

- $\quad$ o seu núcleo ativo sempre ficou restrito a um número que oscilou entre 12 a 20 integrantes;

- não foi estruturado juridicamente, apesar da várias tentativas e minutas de estatutos pesquisadas e discutidas, em função da dedicação a problemas elencados como prioritários e organização de eventos;

- peso diferencial de seus participantes, com claras lideranças por parte da professora coordenadora e universitários, bem como envolvimento diferencial entre os proprios alunos;

- composta, ao contrário da descrição, por estudantes de primeiro grau mas com liderança de estudantes universitários, nenhum profissional participante;

- $\quad$ eixo central da atuação voltada na luta para a implantação de uma área verde urbana de importância histórica e paisagística;

- $\quad$ confronto (muita vezes não explícito) com o poder público local;

- $\quad$ não obteve sucesso na sua luta principal (implantação do Parque) mas a participação contribuiu para a formação de seus integrantes. 
Portanto, segundo essa descrição as características do Grupo Ecológico Cascata Branca remetem ao periodo fundacional do ambientalismo brasileiro, mas consideramos que esse processo de surgimento e estabelecimento de novas entidades é permanente e trilha caminhos muitas vezes coincidentes.

O início da inserção do discurso ambientalista na política institucional brasileira também é uma característica desse periodo fundacional segundo Viola (1982), assim como a eleição de Fábio Feldmann para o Congresso Constitucionalista de 1986. Destacou-se nesse período a incorporação da questão da justiça social dentro do ideário ambientalista, enquanto que a relação dos problemas ambientais com o desenvolvimento econômico segundo Viola (1982) continuou sendo inseridos de forma ingênua pelo ambientalismo.

A outra fase do ambientalismo brasileiro se deu na segunda metade dos anos 80 segundo Viola (1982), com o crescimento no número de entidadades ambientalistas, passando de 400 em 1985 para cerca de 700 em 1989, sendo que a principal diferenciação se deu pela institucionalização, sob duas dimensões:

1. "a emergência de novas organizações com um perfil profissional, corpo técnico e administrativo pago pela organização; captação sistemática de recursos financeiros, definição precisa da área de atuação da organização com metas concretas viáveis e avaliação do desempenho para atingir metas;

2. a profissionalização parcial de um setor das associações que tinham sid o previamente amadoras" (Viola, 1992, p. 61).

Essa etapa não foi conseguida pelo Grupo Ecológico Cascata Branca, devido ao processo de desestruturação causado por uma série de fatores, já elencados.

Viola (1982) destaca nesse fase o crescimento numérico dos grupos amadores nessa fase, com uma tendência de declínio quanto ao seu impacto social-político, por se tratar segundo a opinião desse autor de uma cultura espontaneísta:

««c (...) promovem passeios ecológicos, fazem algumas

denúncias (com menos eficácia que a imprensa): às vezes optam 
pelas "ações diretas", com objetivo de impacto mais "simbólico" do que "real". Constituem a maioria ainda, disseminadas por quase todo o país"' (Viola, 1992, p.62)

O Grupo Ecológico Cascata Branca engrossou a lista dessas entidades amadoras, mas o presente estudo busca a comprovação de que, independente do profissionalismo de estruturação, o papel dessas pequenas entidades não pode ser desprezado dentro da perspectiva de mudanças locais e contribuição para a sensibilização da população e da formação crítica de seus participantes, dentro de um processo educativo.

Segundo Viola (1992), a evolução do ambientalismo brasileiro seguiu com o aumento da profissionalização de algumas entidades e com a interação com outros movimentos sociais, como o movimento dos atingidos por barragens, o movimento dos seringueiros capitaneado por Chico Mendes, o movimento indigena, alguns setores do movimento sem-terra, o movimento de mulheres, setores dos movimentos de bairros, o movimento pacifista, os movimentos de defesa do consumidor, movimentos pela saúde ocupacional,um setor reduzido do movimento estudantil e os grupos voltados para 0 desenvolvimento do potencial humano (acupuntura, ioga e outros).

A tentativa de criação e estabelecimeto de um partido verde no Brasil foi citado por Viola (1982) como integrante desse processo evolutivo do ambientalismo brasileiro, com muitas discordâncias dentro do movimento sobre a viabilidade do projeto, alguns avanços pontuais (eleições do Rio de Janeiro em 1986, onde Gabeira conseguiu 8\% dos votos), com posterior crise.

A partir de 1988, Viola (1992) destaca a incorporação da problemática do desenvolvimento sustentável pelo ambientalismo e a o fato novo com a decisão do Governo em sediar a Conferência das Nações Unidas sobre Ambiente e Desenvolvimento, a RIO-92 e a conseqüente mobilização das organizações não governamentais ambientalistas e sócio-ambientais. Os Fóruns preparatórias passaram de 40 entidades participantes em junho de 1990 para mais de 800 em julho de 1991.

Nesse período o Grupo Ecológico participou do Fórum realizado em São Paulo (julho de 1991) tendo o autor como representante, sendo as propostas levadas para o conhecimento e discussão com os demais integrantes do Grupo, na tentativa de contribuir 
com a própria formação dos seus integrantes dentro de uma perspectiva de envolvimento com a grande mobilização anterior a realização da Conferência.

Nesse periodo, Viola (1992) destacou também a interinfluência entre o movimento ambientalista $\mathrm{e}$ as políticas das agências estatais ambientais federais e estaduais do Sul-Sudeste.

$\mathrm{Na}$ segunda metade dos anos 80 o autor associa a disseminação da preocupação do preocupação pública com a deterioração ambiental com a transformação do ambientalismo num movimento multissetorial, com a inserção de setores como os grupos e instituições científicas das universidades que passaram a abordar a problemática ambiental de um modo interdisciplinar, assim como setores restritos do empresariado,destacando-se a fundação em 1991 da Sociedade Brasileira para o Desenvolvimento Sustentável. Viola (1992) identifica então três posições sobre o desenvolvimento sustentável: a estatista, na qual o Estado deve ser o lócus privilegiado de um novo desenvolvimento social e ambiental sustentável; a comunitária, pela qual os movimentos sociais e organizações não governamentais é que devem ser o lócus dessa mudança, e a de mercado que através de mecanismos de autoregulação (taxas/tarifas de depleção e outros mecanismos dentro dos princípios da Economia Ecológica) é que comporia esse lócus privilegiado de um novo desenvolvimento sustentável.

A ocorrência da Conferência das Nações Unidas sobre Ambiente e Desenvolvimento e o Fórum Internacional de Organizações Não Governamentais e Movimentos Sociais, com seus avanços e retrocessos, foi um marco referencial no ambientalismo brasileiro, resultado de anos de mobilização e articulação por parte das entidades, assim como do Governo, que bem ou mal incorporou a agenda ambiental em sua estrutura, ainda que carente de uma articulação efetiva e com resultados práticos signiticativos na superação dos problemas sócio-ambientais.

Do ponto de vista da sociedade civil, a nível global foi extremamente válido o Fórum, com a formação de redes de informações, intercâmbios e propostas concretas na forma de 36 Tratados discutidos e aprovados (FORUM, 1992).

A Agenda 21 sintetizou os compromissos assumidos pelos países na "Conferência Oficial", com um documento dividido em 04 seções: dimensão social e econômica, 
gerenciamento e conservação de recursos para o desenvolvimento, fortalecimento dos grupos sociais e meios de implementação. Segundo Sato \& Santos (1992) a Agenda 21 reflete o consenso global e as responsabilidades políticas no mais alto nível de integração entre desenvolvimento e ambiente.

Dentro do esforço pós-Rio 92, foi criada a Comissão Pró-Agenda 21-Rio para a divulgação dos seus objetivos e estímulo para a implementação das Agendas 21 locais. A temática da Agenda 21 local foi objeto do Curso de Extensão Universitária 'Áreas Verdes Urbanas, Educação Ambiental e Cidadania".

Destacamos no momento pós-Rio 92 a realização da reunião internacional Rio + 5 , onde se procurou avaliar o cumprimento dos acordos da Rio 92. Nesse encontro, o Fórum Brasileiro de ONGs publicou o livro Brasil século $X X I$, trazendo os resultados de uma consulta nacional sobre essa avaliação e as posições de diferentes grupos de trabalho do Fórum (Agricultura, Biodiversidade,Desertificação, Assentamentos Humanos e outros). A organização de redes temáticas como Mata Atlântica, Cerrados, Águas, Educação Ambiental e outras indicam a continuidade e aprimoramento dessas organizações (Vieira \& Bredariol, 1998).

Consideramos que a participação de cidadãos em entidades ambientalistas efetivamente podem contribuir para a conquista da cidadania. Do depoimento de exintegrantes do Grupo Ecológico obsevamos esse fato. Mas que cidadania é essa que pretendemos ampliar e conquistar?

Segundo Chauí, citada por Vieira \& Bredariol (1998),

"A cidadania, definida pelos limites da democracia, se constitui na criação de espaços sociais de luta (movimentos sociais) e na definição de instituições permanentes para a expressão política (partidos, órgãos públicos), significando necessariamente conquista e consolidação social e política. A cidadania passiva, outorgada pelo Estado, se diferencia da cidadania ativa em que o cidadão, portador de direitos e deveres, é essencialmente criador de direitos para abrir novos espaços de participação política"(Chaú, citada por Vieira \& Bredariol, 1998, p.35-36). 
Vieira \& Bredariol (1998) colocam que os movimentos sociais, através de suas lutas, transformam os direitos declarados formalmente em direitos reais, sendo que as lutas pela igualdade e liberdade ampliaram os direitos civis e políticos da cidadania e criaram os direitos sócias, os direitos das minorias (mulheres, crianças, idosos, minorias étnicas e sexuais) e pelas lutas ecológicas o direito ao ambiente sadio.

Esses mesmos autores defendem uma "Nova Cidadania", em função do surgimento de novos direitos como a autonomia do próprio corpo, a moradia e a proteção ambiental, exigindo uma nova sociedade, com uma necessária maior igualdade nas relações sociais, novas regras de convivência social e um novo sentido de responsabilidade pública, com o reconhecimento dos cidadãos como sujeitos de interesses válidos, de aspirações pertinentes e direitos legítimos.

Além da questão do exercício da cidadania, destacamos o papel educacional que essas organizações ecologistas desempenham, corroborando as conclusões de Sorrentino (1988) a respeito dos objetivos da educação ambiental desenvolvidos pelas mesmas através da práxis:

1. "Propiciar a cada indivíduo vivências e reflexões que o fortaleça no conhecimento de si próprio e do contexto onde vive, nos seus valores e na luta por suas causas;

2. Preparar seus participantes para a prática organizacional democrática a partir da diversidade;

3. Contribuir na delimitação da utopia (ecológica?) para cada individuo/grupo e na sua verbalização/problematização para o movimento ecológico. Contribuir na escolha de caminhos para sua materialização e na revisão constante dos seus contornos (dos caminhos e objetivos) em cada indivíduo/grupo e no movimento como um todo;

4. Ser instância pedagógica, demonstrando à sociedade a viabilidade de se fazer algo e sensibilizando pessoas para a questão ecológica, através da difusão de informações sobre problemas 
ambientais e de análises sobre esses problemas numa perspectiva ecológica;

5. Ser um ponto de apoio e referência para as pessoas, em suas lutas pela melhoria da qualidade de vida e pela proteção da natureza (para não se sentirem sozinhas e sentirem a solidariedade de iguais na luta por essa causa);

6. Formar pessoas para atuação cotidiana em outras organizações e instituições dentro de uma perspectiva de educação pautada por objetivos, conteúdos e metodologias oriundos do vivenciado junto ao movimento ecológico" (Sorrentino, 1988, p. 275-276).

Caberia agora uma introdução breve sobre a questão das políticas públicas e o papel do poder público na questão ambiental.

Segundo Vieira \& Bredariol (1998), a primeira idéia que se tem de uma política pública é a de um conjunto de ações de organismos estatais com o objetivo de equacionar ou resolver problemas da coletividade, e que ao analisar políticas públicas percebemos que além do Estado, atores sociais e políticos participam da sua formulação ou da sua execução.

Citando Haroldo Abreu, Vieira \& Bredariol colocam que

“(...) políticas públicas são mediações político-institucionais das inter-relações entre os diversos atores presentes no processo histórico-social em suas múltiplas dimensões (economia, política, cultura, etc.) e implementadas por atores políticos através de instituições públicas" (Vieira \& Bredariol, 1998, p.78).

Os mesmos autores destacam a diferença entre política pública e política de governo, porque esta última se refere a um mandato eletivo e aquela pode atravessar diversos mandatos.

Outras observações pertinentes dos autores merecem destaque, referente a composição da pauta política: 
"Uma pauta de politica pública é o conjunto de temas dessa política que compõem as preocupações atuais dos atores mais influentes num determinado período. Ela representa resultados de negociações, dentro de correlações de forças entre atores, com o predomínio do atendimento dos interesses de grupos hegemônicos nas relações de poder na sociedade.

Uma questão se torna objeto de políticas públicas, não em função da gravidade que assuma para um ator social, mas em função de interesses que envolve, da consciência, da organização dos discursos, dos argumentos e das pressões que são construídos para inseri-la na pauta política"(Vieira \& Bredariol, 1998, p. 79)

Esse conceito contribui para clarificar as dificuldades enfrentadas pelo Grupo Ecológico na gestão "Zeca Padeiro", pois com base no relato e da entrevista com o mesmo fica claro que a questão ambiental não fazia parte de nenhuma política pública. $O$ Grupo não conseguiu incluir essa pauta apesar das pressões, tendo inclusive participado ativamente na concepção e implantação da Lei de Política Municipal de Meio Ambiente em 1991, que apesar de aprovada nunca foi posta em prática. O grupo hegemônico na época não abriu espaço para a discussão e implantação de uma política ambiental, tendo influência também outros fatores como já visto: a percepção do Prefeito na época da inexistência de problemas ambientais significativos, a pouca expressividade da área objeto de reiivindicação para implantação do Parque, o grau de parentesco do autor com um adversário político, os problemas considerados emergenciais e mais prioritários, dentre outros.

Mesmo com o ingresso do autor no poder público, novamente constatamos que não houve a inclusão da questão ambiental como uma política pública, apesar da maior experiência administrativa e percepção mais apurada da existência e magnitude dos problemas sócio-ambientais de Votorantimo pelo ex-prefeito Erinaldo Alves da Silva.

Analisando as políticas ambientais públicas após um breve retrospecto histórico, Ferreira (1998) citou que com base em trabalhos anteriores a total desvinculação entre as políticas ambientais e demais políticas públicas no Brasil, nos niveis federal e estadual. 
Analisando o governo Fernando Henrique Cardoso, Ferreira (1998) observou que a questão ambiental ainda não é considerada uma política social, estando desvinculada das demais políticas públicas, nem mesmo considerada uma política de desenvolvimento, estando ainda desvinculada das demais políticas econômicas, estando a problemática ambiental ainda sob a ótica do "conservacionismo", um paradoxo frente o discurso atual de modernização da sociedade brasileira de vinculação entre desenvolvimento econômico e problemas de degradação ambiental.

Ferreira (1998) considera porém relevantes iniciativas locais de políticas inovadoras na área ambiental, citando que enquanto a política ambiental federal declinou em termos de importância política, ocorreram experiências inovadoras junto ao poder local. Mais inovador ainda segundo a autora é que esse processo se estendeu a várias cidades brasileiras, com o Estado de São Paulo contendo exemplos importantes nesse processo.

Tendo como objetivo analisar estas experiências de poder local, através do estudo da formulação e da implementação de políticas públicas com características socioambientais, Ferreira (1998) definiu algumas cidades que elegeram novos atores políticos após 1989, entre as quais São Paulo, Campinas, Santos, Piracicaba, Sumaré e Cosmópolis, governadas na época do estudo pelo Partido dos Trabalhadores (PT).

O que chama a atenção nesses municípios estudados foi a diversidade de situações e problemas, alguns até similares aos relatados, como o caso de Cosmópolis, onde em 1989 não havia nenhum órgão voltado a questão ambiental, sendo então criada uma Assessoria de Meio Ambiente, que tentou articular a criação e implantação do Condema (Conselho municipal de defesa do meio ambiente) sem sucesso, além do fato de, assim como Votorantim, possuir uma legislação ambiental relativamente avançada que não é posta em prática. Em Sumaré também foi constatado o fato da distância entre o "discursolegislação" bastante "ambientalizado" e o cumprimento dessa legislação pelo poder público.

No caso de Piracicaba, destacou-se a nível macropolítico a formação do consórcio intermunicipal da bacia do rio Piracicaba e Capivari, sendo que as entidades ambientalistas locais reconheceram essa iniciativa mas questionaram a falta de uma 
política local de saneamento e preservação de matas ciliares. O lixo, segundo Ferreira (1998) foi um dos principais problemas enfrentados, com ênfase no lixo hospitalar. Ocorreram sérias polêmicas com os setores da sociedade civil ligados à questão ambiental na questão da ocupação das áreas verdes de preservação permanente por favelas, com posições antagônicas, sendo definida a estratégia de ocupação por direito adquirido de áreas verdes que não eram de preservação permanente antes da Constituição Estadual.

No caso de Santos, de forma geral segundo Ferreira (1998) houve disposição da gestão em prover o município de legislação adequada e foram desenvolvidos projetos significativos, com efetiva participação da sociedade civil.

Em Campinas, o estudo constatou avanços relativos com a criação de uma estrutura administrativa específica para a área ambiental, apesar de problemas na liderança dessa estrutura e pelo fato de não ter se conseguido debater adquadamente durante o processo de elaboração do Plano Diretor, bem como ter levado três anos para retivar o Conselho municipal de meio ambiente.

Em São Paulo foi resumidamente destacado que, apesar da existência de condições em termos de recursos técnicos e humanos, não ter se conseguido implantar uma política municipal de meio ambiente efetiva.

Dessa rápida leitura, observamos que de mesmo com uma legislação avançada, os comportamentos individuais, as politicas públicas e as condições para sua aplicação encontram-se restritas e aquém do discurso, fato destacado também nas entrevistas com ex-integrantes do Grupo Ecológico e ex-prefeitos.

Outro fato é que o processo de urbanização tardia e desenfreada trouxe reflexos nas cidades, Votorantim sendo um bom exemplo disso, com problemas graves como habitação, saúde, poluição, necessidade de escolas, organização de sistemas de abastecimento, saneamento básico e outros.

Segundo Ferreira (1998):

"Os municípios situam-se na linha de frente dos problemas ambientais, mas estão no último escalão da administração pública. 
Há um deslocamento generalizado dos problemas para a esfera local, enquanto as estruturas político-administrativas continuam centralizadas. Em conseqüência, criou-se um tipo de impotência institucional que dificulta dramaticamente qualquer modernização da gestão local, enquanto favorece o tradicional caciquismo articulado com relações fisiológicas nos escalões superiores.

Com o processo de urbanização, os problemas se deslocaram, mas não o sistema de decisão correspondente. Assim, o que temos hoje é um conjunto de problemas modernos e uma máquina de governo característica das necessidades instituicionais dos anos 50" (Ferreira, 1988, p. 54).

Esse fato encontra-se bem representado em Votorantim. Os prefeitos entrevistados foram bastante contundentes na explanação sobre um "princípio das necessidades emergenciais" que foi decisivo principalmente no período de estruturação do município, uma vez que segundo os mesmo sempre necessidades emeergenciais (saúde, educação, saneamento) impediram a atenção e atitudes frente à problemática ambiental.

Porém, mesmo com o avanço e inserção da questão ambiental na sociedade nas últimas décadas, não ocorreram mudanças na estrutura do poder que permitissem o entendimento da questão ambiental não como algo acessório ou figurativo-estético mas como algo intimamente ligado a qualidade de vida, envolvendo a inter-relação com outras políticas públicas como saneamento, educação e saúde.

Menezes (1997), fazendo um amplo histórico da emergência e evolução da política ambiental urbana do Brasil do Estado Novo à Nova República, conclui que no período relativamente recente de redefinições do papel político do município na gestão ambiental urbana, é apontada uma nova relação administração/sociedade civil, sendo que tantos os governantes quanto as organizações da sociedade civil ainda se encontram permeados pela cultura política centralizadora, estando em um momento de definições e redefinições de espaço de atuação, de busca de legitimidade, em um processo de aprendizado democrático que possa sinalizar para o equiibrio e convívio das diferenças, 
tendo como resultado possível ações comuns que assegurem o equilíbiro ecológico como meta e necessidades comuns.

Esse processo, em Votorantim, ainda não trouxe resultados no que diz respeito a estruturação e capacitação do poder público para o tratamento das questões ambientais.

Ainda segundo Menezes (1997)

"Tudo irá depender, por um lado, da vontade política dos governantes locais de ativar uma engenharia institucional que garanta a coordenação dos níveis de gestão no plano institucional, político e territorial. Por outro lado, dependerá de articulação e competência da sociedade civil em buscar mecanismos que permitam institucionalizar os canais de participação, tornando-os legitimos em suas formas de representação e em seus poderes e possibilidades de influenciar ações governamentais. No desmembramento desse processo é que poderá haver possibilidades reais para a emergência e evolução de um novo modelo de desenvolvimento urbano: político, econômico, social e ambientalmente sustentável" (Menezes, 1997, p.92)

Analisando a experiência vivida e relatada, observamos que faltou e ainda falta em Votorantim a vontade política enquanto elemento essencial para deflagrar processos de mudança e inserção da questão sócio-ambiental, sendo essse um dos fatores fundamentais e sem o qual não se inicia qualquer processo. 


\subsection{O curso de extensão cultural "Áreas Verdes Urbanas, Educação Ambiental e Cidadania"}

\subsubsection{Justificativas}

A proposta de trabalho original do autor, apresentada em agosto de 1996 dentro da Disciplina de Pós-Graduação "Seminários em Ciências Florestais" intitulou-se "Proposta Participativa de Elaboração de um Projeto de Parque Municipal no Município de Votorantim, S.P." Entre os objetivos expostos, incluía-se:

"Elaborar uma estratégia de envolvimento da população e setores organizados da sociedade local no diagnóstico, concepção geral, definição e se possível início de implantação de um espaço livre de uso público - o Parque Municipal da Cachoeira, em Votorantim, S.P." (Melo, 1996).

Porém, a falta de apoio institucional em função das divergências que, embora nunca claramente explicitadas pela administração eram expressas na própria falta de acesso ao diálogo e no não encaminhamento das propostas e projetos do autor voltados à questão ambiental local, inviabilizaram essa proposta. Pretendia-se, calcado nos principios da Pesquisa-participante/Pesquisa-ação iniciar todo um processo que mobilizasse novamente a entidades organizadas e cidadãos interessados na implantação do Parque, porém já no Plano de Trabalho essa dificuldade foi claramente expressa:

"Surge então um dilema a ser resolvido: como se daria a participação do autor, funcionário responsável pela área ambiental da Prefeitura (único) e na época de existência do Grupo Ecológico Cascata Branca um de seus membros mais atuantes? Seria possível "separar" a formação do grupo de pesquisa-ação com as responsabilidades (até agora não assumidas) do poder público sobre uma área que lhe pertence e encontra-se praticamente abandonada? Como se dariam as necessárias e possivelmente inevitáveis pedidos 
de providências e colaboração de grupo de pesquisa-ação com a Prefeitura?

Uma possível resposta talvez seja fazer com que a Prefeitura, com o início da nova administração em 1997, "oficialmente" apóie e estimule a atuação desse grupo de pessoas/entidades interessadas em viabilizar um projeto participativo para a área, inclusive fazendo com que o projeto "não-participativo" terceirizado existente seja discutido e possivelmente aprefeiçoado ou alterado. Uma vez que isso não seja possível, teremos uma situação dificil, com prováveis embates entre a visão do grupo e a do $\mathrm{Sr}$ Prefeito."(Melo, 1996).

Como já foi exposto, apesar do compromisso assumido em campanha, o Prefeito eleito para a gestão 1997/2000 não tomou nenhuma atitude prática para o encaminhamento das propostas de estruturação da área de meio ambiente, apresentadas pelo autor com ampla divulgação na imprensa local. Também o autor não conseguiu nem mesmo acesso ao projeto para a área da cachoeira elaborado pela empresa particular em 1995, apesar dos vários pedidos por escrito efetuados no início da gestão.

Essa situação levou o autor a discutir com seu orientador sobre como encaminhar a incorporação da participação de pessoas e entidades interessadas na questão ambiental dentro da discussão da problemática das áreas verdes urbanas e especificamente sobre a área da Cachoeira, no escopo do trabalho da presente Dissertação. Uma alternativa encontrada foi para desenvolver uma atividade participativa foi a elaboração de um Curso de Difusão Cultural patrocinado pela USP, como uma atividade de extensão universitária, com o seguinte tema: "Áreas Verdes Urbanas, Educação Ambiental e Cidadania".

Para melhor compreender as motivações pela incorporação da participação enquanto elemento essencial para o desenvolvimento de uma proposta de educação ambiental voltada para problemas urbanos, no caso a questão dos espaços livre de uso público, cabe uma introdução sobre o tema. 


\subsubsection{Participação - uma revisão}

Esta revisão pretende promover uma reflexão sobre a questão teórica e prática da participação enquanto processo de pesquisa, construção do conhecimento e transformação da realidade, dentro da perspectiva do desenvolvimento de projetos de atividades na área de Educação Ambiental.

Para exemplificarmos a importância dessa temática, citamos o fato de que, de uma turma de pós-graduandos de Ciências Florestais da Escola Superior de Agricultura "Luiz de Queiroz" (ESALQ/USP) iniciada em 1996, a maior parte desses alunos teve sua área de interesse voltada para o setor de Ambiência (Manejo e Recuperação de Fragmentos Florestais, Manejo de Fauna Silvestre, Florística e Fitossociologia de formações florestais, Educação Ambiental e outros temas), e um fato significativo é que vários desse projetos possuíram entre seus elementos principais a palavra "participação".

Seja de forma mais direta e como elemento principal do processo de pesquisa, através de métodos das áreas de Ciências Sociais como a pesquisa-participante e a pesquisa-ação, ou através de outros métodos e técnicas onde se buscou o envolvimento, informações e opiniões do "público-alvo" como a observação-participante, técnicas de entrevista e outras, a "participação" foi uma palavra-chave e esteve presente nesses trabalhos de pesquisa.

Podemos citar trabalhos como a elaboração participativa de um Plano de Gestão da Educação Ambiental na ESALQ, a produção do saber sobre floresta por camponeses assentados, o diagnóstico da extensão florestal em programas de recuperação de matas ciliares, os motivos pela aceitação ou não dos plantios florestais por proprietários rurais dentro de um Plano de Desenvolvimento Florestal elaborado pelo Governo do Estado, o uso de sistemas agro-florestais para a recuperação de fragmentos florestais com a participação dos agricultores, dentre outros.

São variados os motivos pelos quais se buscou a participação nesses projetos, muito em função da própria percepção dos pesquisadores da complexidade e interrelações das questões (sociais, ambientais, econòmicas) e da necessidade de buscar respostas concretas (mas não definitivas) frente a essa realidade complexa e 
multifacetada. A própria experiência de vida e trabalho, o compromisso político e outros motivos certamente contribuíram para esse tipo de abordagem de problemas enquanto objeto de pesquisa científica.

Não cabe aqui uma análise mais aprofundada sobre essas motivações, mas convém iniciar um debate sobre o próprio conceito, importância e processo da participação. É o que nos propomos nessa revisão, dando indicações para um maior aprofundamento através de literatura, bem como colocamos como anexo informações complementares sobre pesquisas realizadas pelo autor sobre o tema.

\subsubsection{Participação: conceitos, maneiras, princípios}

Segundo Bordenave (1985):

“A participação é uma necessidade humana universal (...) É o caminho natural para o homem exprimir sua tendência inata de realizar, fazer coisas, afirmar-se a si mesmo e dominar a natureza e o mundo. Além disso, sua prática envolve a satisfação de outras necessidades não menos básicas, tais como a interação com os demais homens, a auto-expressão, o desenvolvimento do pensamento reflexivo, o prazer de criar e recriar coisas, e, ainda, a valorização de si mesmo e dos outros (...) é inerente à natureza social do homem, tendo acompanhado sua evolução desde a tribo e o clã dos tempos primitivos, até as associações, empresas e partidos políticos de hoje. Neste sentido, a frustração da necessidade de participar constitui uma mutilação do homem social (...) Tudo indica que o homem só desenvolverá seu potencial pleno numa sociedade que permita e facilite a participação de todos. O futuro ideal do homem só se dará numa sociedade participativa"(Bordenave, 1985, p. 16-17)

Etimologicamente, a palavra "participação" vem da palavra parte, e significa fazer parte, tomar parte e ter parte. Essas palavras indicam os níveis diferentes de 
participação: podemos, por exemplo, fazer parte de um grupo mas não tomar parte de decisões importantes, fazer parte de uma empresa mas não ter parte nos lucros. A participação pode então ser ativa quando não só fazemos, mas tomamos parte das decisões de um grupo, ou passiva quando apenas fazemos parte de uma organização qualquer (Bordevave, 1985).

Ainda segundo Bordenave (1985):

"Uma sociedade participativa seria então aquela em que todos os cidadãos têm parte na produção, gerência e usufruto dos bens da sociedade de maneira equitativa. Toda a estrutura social e todas as instituições estariam organizadas para tornar isso possivel. Assim, a construção de uma sociedade participativa converte-se na utopiaforça que dá sentido a todas as microparticipações. Neste sentido, a participação na família, na escola, no trabalho, no esporte, na comunidade, constituiria a aprendizagem e o caminho para a participação em nível macro numa sociedade onde não existam mais setores ou pessoas marginalizados. Aos sistemas educativos, formais e não-formais, caberia desenvolver mentalidades participativas pela prática constante e refletida da participação"

(Bordenave, 1985, p 25-26).

Pode ser que a utopia-força descrita por esse autor seja o que as pessoas envolvidas e interessadas na pesquisa e desenvolvimento de processos participativos intuitivamente buscam e têm como referência.

Bordenave (1985) classifica os tipos de participação em:

- de fato: primeiro tipo de participação, surge com a humanidade na família nuclear e clã, tarefas de subsistência (caça, pesca, coleta), culto religioso, recreação, defesa contra inimigos;

- espontânea: grupos fluidos, sem organização estável e propósitos claros e definidos como as "gangs" e "panelinhas", necessidade de satisfazer necessidades psicológicas de pertencer, expressar-se, etc.; 
- imposta: indivíduo é obrigado a fazer parte de grupos e realizar certas atividades consideradas indispensáveis, como as cerimônias e rituais de passagem das tribos indígenas, a missa dominical dos católicos e o voto obrigatório nas eleições, por exemplo;

- voluntária: grupo criado pelos próprios participantes, que definem sua própria organização e estabelecem seus objetivos e métodos de trabalho, como os sindicatos livres, cooperativas, partidos, etc.;

- provocada: quando a participação voluntária não surge, agentes externos podem atuar para ajudar os outros a realizarem seus objetivos ou os manipulam a fim de atingir seus objetivos previamente estabelecidos (nesse caso, pode-se falar de participação dirigida ou manipulada). A extensão rural, o serviço social, o desenvolvimento de comunidades, trabalhos de pastoral são exemplos de enfoques mais ou menos institucionalizados de participação provocada.

- concedida: parte de poder ou de influência exercida pelos subordinados e considerada como legítima por eles mesmos e pelos superiores, como a participação nos lucros das empresas pelos trabalhadores"(Bordenave, 1985).

Essa caracterização dos tipos de participação é interessante, pois nos auxilia a compreensão sobre esse processo e contribui para que tenhamos uma visão um pouco mais crítica, afinal conforme o tipo de participação existe ou não uma contribuição para o processo de tomada de consciência acerca dos problemas ambientais e suas relações com outras questões.

Apenas para exemplificar, constatamos nos últimos anos, através do aprimoramento da legislação ambiental, o surgimento e consolidação de órgãos colegiados como o CONAMA-Conselho Nacional de Meio Ambiente (Federal), os CONSEMAS (Conselhos Estaduais de Meio Ambiente) e COMDEMAS (Conselhos Municipais de Defesa do Meio Ambiente), onde existe a participação dos governos e 
entidades da sociedade civil. Representando um espaço para a discussão de políticas públicas e a tomada de medidas como a avaliação/aprovação de Estudos de Impacto Ambiental/Relatórios de Impacto sobre o Meio Ambiente (EIA/RIMA), de um lado dão substância ao discurso dos governantes de "espaço de participação de toda a sociedade", de outro lado freqüentemente são alvo de fortes críticas dessas entidades em função da participação "figurativa", sem poder de intervenção concreto, servindo apenas para um referendo "politicamente correto" das decisões e ações das diferentes esferas de governo.

O esquema a seguir, ilustra alguns graus que pode alcançar a participação numa organização qualquer, do ponto de vista do menor ou maior acesso ao controle das decisões pelos membros (Bordenave, 1985-pg. 31):

Figura 01 - Graus de participação segundo Bordenave (1985)

GRAUS DE PARTICIPACĀO

[BOADENAVE, 1985]

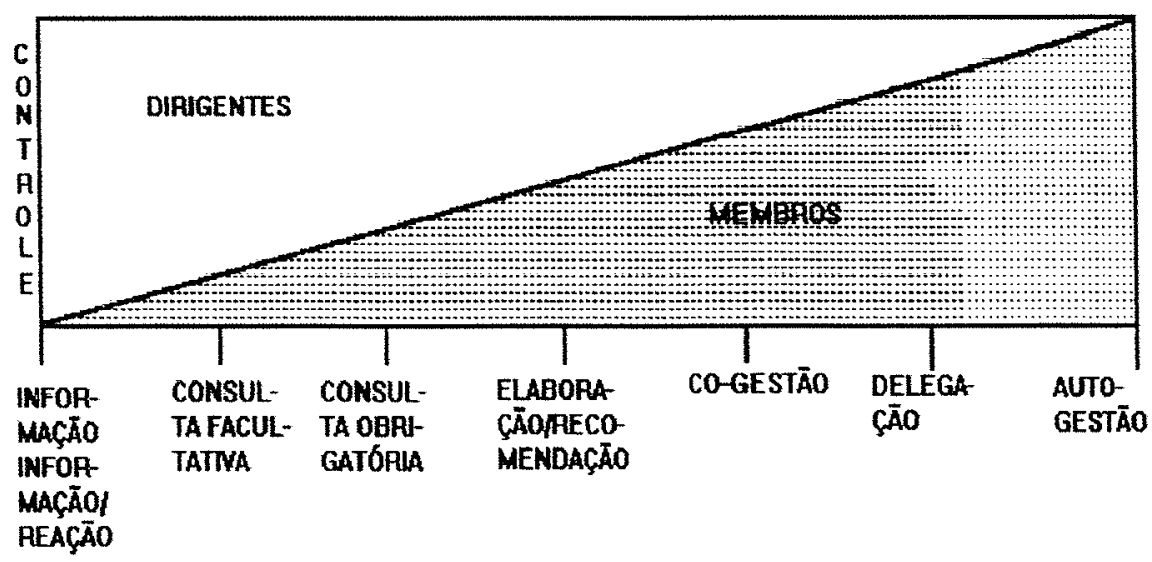

Fonte: Bordenave, 1985, p.31 
Esse esquema permite uma reflexão bastante pertinente sobre a relação entre os graus de participação e o controle do processo pelos membros e dirigentes, e remete inclusive a forma de participação que incorporamos no nosso discurso e prática. De um lado, temos uma situação de apenas informação-informação/reação, onde os dirigentes (ou, por exemplo, Poder Público Federal, Estadual ou Municipal) já tomaram as decisões, sendo o menor grau de participação. Segundo Bordenave (1985, p.31) "por pouco que pareça, isso já constitui uma certa participação, pois não é infreqüente o caso de autoridades não se darem ao trabalho de informar seus subordinados".

Em outro extremo, temos o mais alto grau de participação, a autogestão, na qual o grupo determina seus objetivos, escolhe seus meios e estabelece os controles pertinentes, sem referência a uma autoridade externa. Podemos dizer que a autogestão enquanto processo e forma de poder é uma meta que faz parte do ideário ambientalista desde seu surgimento.

Finalizando essa parte introdutória, Bordenave (1985) propõe alguns "princípios" da participação que considera básicos para orientar o processo:

1. "A participação é uma necessidade humana e, por conseguinte, constitui um direito das pessoas.

2. A participação justifica-se por si mesma, não por seus resultados.

3. A participação é um processo de desenvolvimento da consciência crítica e de aquisição de poder.

4. A participação leva à apropriação do desenvolvimento pelo povo.

5. A participação é algo que se aprende e aperfeiçoa.

6. A participação pode ser provocada e organizada, sem que isto signifique necessariamente manipulação.

7. A participação é facilitada com a organização e a criação de fluxos de comunicação.

8. Devem ser respeitadas as diferenças individuais na forma de participar. 
9. A participação pode resolver conflitos mas também pode gerálos.

10.Não se deve "sacralizar" a participação: ela não é panacéia nem é indispensável em todas as ocasiões."(Bordenave,1985,p.77-81).

Esses pontos podem servir de elementos para avaliarmos que participação queremos e demonstrar a dimensão politica e emancipatória do processo de participação na construção do conhecimento e transformação da realidade.

As propostas de pesquisa-participante envolvem uma participação provocada, que pode e deve ser legítima se a intenção dos proponentes (agentes externos) for de um espírito de parceria e de respeito, tendo a perspectiva de valorização do processo de construção de conhecimento e despertar da consciência individual/coletiva, bem como uma instrumentalização para a ação que seja responsável e não demagógica, e que tenha uma perspectiva de continuidade do processo sem a dependência de agentes externos, no caso de projetos de desenvolvimento rural, por exemplo.

Nesta ótica, é de fundamental importância que os pesquisadores tenham uma postura de respeito à diversidade de opiniões e formações e não tentem impor sua visão de mundo e "soluções", baseadas em "verdades" relativas. $\mathrm{O}$ pesquisador ou animador deve então ter sensibilidade para "conduzir" e ser conduzindo pelo processo. Nem sempre o andamento e resultados são os esperados ou desejados por ele, podem até ser contrários, o que não invalida o processo de pesquisa/intervenção desde que o mesmo tenha interesse em compreender o processo e os motivos pelo seus resultados 'não esperados'. Com base em referenciais teóricos, relatos de outras experiências e contato com outros pesquisadores, essa experiência pode contribuir para uma melhor compreensão dos fenômenos sociais envolvendo ações/reflexões.

Vale ainda ressaltar a parte final do texto Pesquisa Social e Ação Educativa, de Oliveira \& Oliveira (1986):

““'A tarefa de pesquisador/educador não é a de"fazer a cabeça" do povo, trazendo do exterior a consciência "lúcida e 
crítica", o esquema de análise "realmente científico" ou a linha "justa e correta" do ponto de vista tático e estratégico. A pesquisa como itinerário político-didático não deve ser a oportunidade para o pesquisador fazer o seu discurso, impor as suas idéias, conduzir o grupo à posição que ele estima correta. Em primeiro lugar, porque isso seria inútil, além de autoritário e mistificador (...) A consciência - como o conhecimento - não se transferem prontos, de fora para dentro, nem da noite para o dia. Consciência $e$ conhecimento se constroem, se estruturam e se enriquecem em cima de um processo de ação e de reflexão empreendido pelos protagonistas de uma prática social vinculada a seus interesses concretos e imediatos'"'(Oliveira \& Oliveira, 1986, p.33)

\subsubsection{Participação e Construção do Conhecimento}

Conforme visto anteriormente, a participação está presente como elemento fundamental em várias propostas de trabalho. Mas quais as origens e fundamentações dessas formas de pesquisa-ação? Segundo Esteves (1987)

“ a quem buscar uma iniciação à "investigação-ação"nos manuais de métodos de investigação social, clássicos ou modernos, está, quase pela certa, reservada uma surpresa tão grande e inesquecível quanto à primeira vista intrigante: a sua ausência, pura $\mathrm{e}$ simples"(Esteves, 1987, p.250)

A chave para o entendimento dessa exclusão está, segundo esse autor, na compreensão do modelo positivista de ciência.

O modelo positivista de ciência aplicada aos fenômenos sociais se acomoda em uma representação (acrítica e ideológica) do seu objeto como realidade inerte e natural, desprovida da historicidade que, mesmo enquanto presente, a caracteriza na sua profundidade. Para Nigel Armistead, citado por Esteves (1987), esta simplificação 
excessiva permitiu transpor para as ciências sociais o modelo metodológico denominado de "processo" para o contrapor ao modelo de "praxis":

"Praxis (literalmente, em grego, significa "um acto") referese ao compromisso de um sujeito humano activo com seu meio, enquanto processo (derivado do latim, que significa "tendo ocorrido") refere-se à experimentação passiva de uma série de sucessos por parte de um objeto.

O nosso comportamento concebe-se como causado por forças naturais e sociais, que estão em grande parte fora do nosso controlo. O modelo de práxis, pelo contrário, acentua o caráter intencional do nosso comportamento embora influenciado por fenómenos culturais e sociais.

Quando se pensa que as coisas acontecem às pessoas, ignorase a forma como elas vêem as coisas e a sua implicação na construção dos conhecimentos" (Armistead, citado por Esteves, 1987, p. 253)

As metodologias de pesquisa de caráter participativo partem então de uma denúncia do caráter fundamentalmente contemplativo dado pelo positivismo ao conhecimento científico e centram-se na explicitação de uma concepção pragmática do conhecimento.

Uma concepção pragmática da teoria do conhecimento nos foi dada por Mao-Tse-Tung (1979). Segundo ele, o processo de desenvolvimento do conhecimento inicia com a observação dos fenômenos através dos sentidos (grau de percepção sensível, estágio das percepções e representações). A partir dessas observações, com a prática social e a reflexão, começam a surgir conceitos ou estabelecer conexões entre fenômenos, chegando-se a conclusões lógicas, partindo-se então do conhecimento sensivel e chegando-se ao conhecimento lógico. 
Essa teoria dialético-materialista do conhecimento reconhece que o conhecimento sensivel e o conhecimento racional ou lógico diferem qualitativamente mas não são separados um do outro, são unidos pela prática. A prática tinha a função de transformação da realidade, no caso a luta de classes e a superação da dominação capitalista. Em sintese, podemos colocar como pontos fundamentais da teoria do conhecimento segundo Mao Tsé-Tung (1979):

1. O conhecimento começa com a experiência;

2. Passa do conhecimento sensivel ao conhecimento racional

3. A partir da compreensão das leis do mundo objetivo, ativamente transformá-lo; adquirindo conhecimento teórico da prática, voltar à prática;

4. Conhecimento como processo: contínua e permanente interação entre as etapas do processo de conhecimento através da prática; ação-reflexão e nova ação-reflexão.

Em sintese

'Pela prática descobrir as verdades, e ainda pela prática, confirmálas e desenvolvê-las. Partir do conhecimento sensivel para elevar-se ativamente ao conhecimento racional, depois partir do conhecimento racional para dirigir ativamente a prática revolucionária, a fim de transformar o mundo objetivo e o subjetivo. A prática e o conhecimento, depois de novo a prática e o conhecimento. Essa forma cíclica não tem fim, e além disso, em cada ciclo, o conteúdo da prática e do conhecimento eleva-se para um nível superior."(Tsé-Tung, 1979, p.83)

É possivel que intuitivamente sigamos alguns princípios dessa teoria (dentre outras) materialista-dialética do conhecimento em nossa vida como profissionais da área ambiental. Porém, não é uma prática muito corrente a realização de uma reflexão mais aprofundada sobre nossas ações, geralmente não há uma retroalimentação com experiências acumuladas ou mesmo teorias ou idéias que possam contribuir com nossa prática.

Esse fato pode decorrer em função da urgência de nossas ações, reflexo da profunda carência de iniciativas de técnicos em ações concretas no mundo extra- 
acadêmico, e também pela falta de uma melhor compreensão dos fenômenos ou espaços/oportunidades para a reflexão, com outras pessoas.

Uma linha de pesquisa baseada na pesquisa-participante ou pesquisa-ação tem uma relação bastante profunda com a práxis ou com a ação-reflexão, pois pressupõe a pesquisa como um processo contínuo e interativo de construção do conhecimento, onde "pesquisadores" - o animador e o grupo-alvo da ação-intervenção conjunta se unem dentro de uma perspectiva de troca de experiências e aumento de conhecimento sobre os fenômenos e sobre si próprios à partir do estudo e intervenção junto à problemas que os afetam.

Para Pedro Demo (1994) surgem questões envoltas na necessidade de prática enquanto questionamento sistemático crítico e criativo, evitando-se tanto o risco do "teoricismo" como o "ativismo marcado pelo mero impulso ideológico ou amadorismo profissional". Existe uma mútua necessidade e independência relativa e dialética da teoria/prática, fundamental para o próprio progresso da Ciência.

Dentro dessa preocupação, cabe destacar uma reflexão colocada por Sorrentino (1995):

“ Não existe uma única teoria, nem uma certa e outras erradas. A cada fazer educativo deve corresponder uma leitura da realidade. Para cada problema ambiental existem diferentes interpretações e pontos de vista e às vezes parece que não se está falando do mesmo problema" (Sorrentino, 1995, p. 12)

Voltado especificamente às ações de educação ambiental e ambientalistas de modo geral, qual o contexto da Teoria? Existem discussões/reflexões sobre questões de fundamentos que embasam a ação? Um fato provável é que, conforme citado anteriormente, em função da total carência dessas ações ou de relativamente poucos indivíduos ou grupos dedicarem parte de seu tempo às questões de interesse público, priorize-se muito mais o ativismo que a discussão/reflexão sobre a prática enquanto processo fundamental para o próprio avanço das ações.

Existe uma série de fatores que contribuem para esse ativismo, entre os quais podemos citar: a crise econômica e marginalização de grande parcela da população, que 
não consegue manter um padrão mínimo de condição de vida, não tem acesso à educação, cultura e informação e seu tempo é dispendido totalmente na tentativa de subsistência; a falta de experiência e vivência democrática, onde espera-se tudo dos governantes e políticos, ficando a "participação popular" restrita à época da eleição; e mesmo a falta de interesse, tendo condições para a participação. Portanto, a participação em questões ambientais parece ainda restrita a um movimento de classe média, "classista", com foi colocado nos depoimentos de ecologistas a seguir (Crespo e Leitão, 1993):

"O movimento ambientalista tem uma prática diferente de outros movimentos sociais. É um movimento de classe média e surgiu da preocupação de pessoas com a preservação da natureza, de uma forma de pensar que não é mais hegemônica, aquela coisa de natureza intocável(...).A luta ambiental sensibiliza as elites letradas mas não é delas, é uma luta da população em geral, do trabalhador. Os militantes podem até ser de classe média, mas o beneficio se estenderá a todos."

"O movimento é e pode ser considerado de classe média por razões de ordem prática, porque o acesso às informações sobre as questões ambientais e o tempo é reduzido no País, e em várias partes do mundo. Um operário, um bancário, que "ralam" dia e noite, não têm tempo nem acesso às informações básicas, daí não se sensibilizarem na mesma medida. Seu processo de engajamento é muito mais lento e dificil. Quanto mais perto, mais próximo ao seu cotidiano, mais fácil é para o homem simples entender a importância dessas questões. O capital social mais importante para a questão ecológica é tempo e informação" (Crespo \& Leitão, 1993, p.39) 
Retornando às questões de fundamento e de concepção ou filosóficas, algumas contribuições mais recentes sobre o próprio papel da ciência corroboram a busca de uma ciência voltada para o mundo real. Prigogine e Stengers (sem data) no livro "A nova aliança", colocam que precisamos superar o padrão de ciência clássica no qual o observador é eliminado e a observação concebida de um ponto de vista exterior ao mundo. Deve haver um diálogo entre as ciências da natureza, as ciências sociais, a filosofia e as outras formas de saber, pois

"chegou o tempo de novas alianças, desde sempre firmadas, durante muito tempo ignoradas, entre a história dos homens, de suas sociedades, de seus saberes, e a aventura exploradora da natureza"(Prigogine e Stengers, s. d., p.401).

Um trabalho mais aprofundado e que dá a inserção das metodologias participativas de investigação social, contendo aspectos epistemológicos, sociológicos, origens, modalidades e procedimentos foi realizado por Esteves (1987) e deve servir de referência para o entendimento dessas propostas, dentre outras disponíveis.

\subsubsection{Pesquisa e Participação}

Segundo ESTEVES (1987, op.cit.), o trabalho pioneiro de "action-research" pertence a Kurt Lewin (1890-1947) dentro da psicologia e na linha de uma certa preocupação com os "problemas sociais" da sociedade americana, dentro de uma perspectiva reformista e conservadora.

Borda (1986) cita que a pesquisa participante, antes de tudo, não se trata do tipo conservador de pesquisa planejado por Kurt Lewin, ou as propostas respeitadas de reforma social e a campanha contra a pobreza dos anos 60 . Refere-se, antes, a uma pesquisa da ação voltada para as necessidades básicas do indivíduo que responde especialmente às necessidades de populações que compreendem operários, camponeses, agricultores e índios - as classes mais carentes nas estruturas sociais contemporâneas levando em conta suas aspirações e potencialidades de conhecer e agir. É a metodologia 
que procura incentivar o desenvolvimento autônomo (auto-confiante) a partir das bases e uma relativa independência do exterior.

Surge então um conjunto de termos que a princípio podem causar confusão: pesquisa participante, pesquisa-ação, observação-participante, investigação-para-a-ação, investigação-na/pela-ação, action-research, participatory-research. Tentaremos esclarecer alguns desses termos.

Action-research , Participatory-research

Aparentemente, o primeiro termo que surgiu enquanto perspectiva de pesquisa foi action-research, conforme visto anteriormente, por Kurt Lewin.

Desse termo derivaram as outras concepções mais críticas voltadas às transformações sociais. Não se conseguiu estabelecer uma distinção deste com o termo participatory-research, também utilizado na literatura internacional sobre o tema. É possivel que a distinção seja dada de forma similar a proposta por Thiollent (1986) entre pesquisa participante e pesquisa-ação, conforme veremos a seguir.

\section{Investigação-para-a-ação}

Segundo Esteves (1987), esta modalidade de investigação-ação não se afasta da investigação tradicionalmente codificada pelos textos de metodologia, consistindo uma versão "fraca" da investigação-ação. Possui os seguintes traços distintivos:

- "Separação total do processo de investigação em relação ao eventual curso de ação sobre o objeto/meio de pesquisa;

- Detenção em exclusivo por parte do investigador (individual e coletivo) da capacidade de recolher e tratar a informação;

- Exclusão do objeto/meio social de pesquisa de qualquer processo tendente a um melhor conhecimento de si como unidade de investigação e sua redução a um estatuto de "reservatório de informações"'”(Esteves, 1987, p.267). 
Segundo Esteves (1987), é a modalidade também denominada "investigação-ação participativa". Tem como características principais o seu caráter complexo (organiza-se em torno de três objetivos distintos: objetivos de investigação, de inovação e de formação de competências) e ser um processo coletivo que, na diversidade de suas ações e das suas fases, envolve como sujeito ativo, já de investigação já de intervenção, não só o coletivo de investigadores, mas também a sociedade, ou parte dela.

É a proposta de pesquisa-participante que mais freqüentemente encontramos em referências e trabalhos voltados à realidade social dos países em desenvolvimento.

Observação-participante

Não se pode confundir a técnica antropológica da observação-participante com a pesquisa-participante. A primeira é uma técnica em que o contato, mesmo prolongado com o "objeto" de estudo, é controlado de modo a evitar, o mais possível, transformações nele. Porém, reconhece-se que a técnica da observação-participante (alguns chamam-na anedoticamente de "participação-observante") não se desenvolve sem implicar transformações no objeto de estudo, por isso se entendeu que as transformações desencadeadas por essa técnica não eram nem deveriam ser objetivos dos propósitos do investigador mas o investigador teria de levá-las em conta na sua análise (Esteves,1987).

\section{Pesquisa-participante}

Não existe um conceito único de pesquisa-participante. Ela deve ser entendida mais como um gênero de pesquisa surgida à partir da crítica aos métodos tradicionais de pesquisa social. Segundo Hall, citado por Demo (1984), “ a PP (pesquisa-participante) e descrita de modo mais comum como uma atividade integrada que combina investigação social, trabalho educacional e ação". Outra definição foi dada por Grossi, citado por Demo (1984):

"É um processo de pesquisa no qual a comunidade participa da análise de sua própria realidade, com vistas a promover uma transformação social em beneficio dos participantes, que são oprimidos. Portanto, é uma atividade de pesquisa, educacional, e 
orientada para a ação. Em certa medida a PP foi vista como uma abordagem que poderia resolver a tensão contínua entre o processo de geração do conhecimento, entre o mundo "acadêmico" e o "real", entre os intelectuais e trabalhadores, entre ciência e vida"(Grossi, citado por Demo, 1984, p.126)

\section{Pesquisa-ação}

Segundo Thiollent (1984), é necessária uma distinção entre os diversos tipos de PP (pesquisa-participante) e diversos tipos de PA (pesquisa-ação). A PA é uma forma de PP, mas nem todas PP são PA. Os partidários da PP não concentraram suas preocupações em torno da relação entre investigação e ação dentro da situação investigada, a PA é um tipo de pesquisa centrada na questão do agir. Uma definição de PA foi dado em outro texto de Thiollent (1985):

“a pesquisa-ação é um tipo de pesquisa social de base empírica que é concebida e realizada em estreita associação com uma ação ou com a resolução de um problema coletivo e no qual os pesquisadores e os participantes representativos da situação ou problema estão envolvidos de modo cooperativo ou participativo" (Thiollent, 1985, p. 14).

\subsubsection{Pesquisas Participantes - Onde se aplicam?}

Após uma breve tentativa de explicitação das várias linhas onde a participação está inserida enquanto perspectiva de pesquisa cientifica, faremos algumas considerações sobre as áreas de aplicação.

Como já foi visto, o pioneirismo da "action-research" se deve a Kurt Lewin, conforme colocado por Esteves (1987) e estava relacionado, na área de psicologia social, a uma certa preocupação com problemas da sociedade americana na época. Segundo Lewin, citado por Esteves (1987), a "action-research" baseia-se numa "acção a nivel realista sempre seguida por uma reflexão autocrítica objectiva e uma avaliação dos 
resultados" e é animada pelo espírito da dupla recusa: "nem acção sem investigação nem investigação sem acção"; a Lewin se deve ainda a compreensão básica dos seus objetivos e do sentido destes no seio da metodologia: "cumpre-nos considerar a acção, a pesquisa e o treinamento como triângulo que se deve manter uno em benefício de qualquer dos seus ângulos" (Esteves, 1987).

As áreas onde se aplicaram essa metodologia, desde sua concepção (Esteves,1987), foram: hábitos alimentares, disposições psicológicas dos militares em guerra, preconceitos, resistência à mudança, formação de quadros, decisões de grupo, comportamentos de bandos de adolescentes, integração de vendedores negros ou de habitantes nos respectivos imóveis de habitação.

Posteriormente, com seu desenvolvimento e diversidade, surgiram críticas e rupturas especialmente no plano dos objetivos e valores que comandam a ação (Esteves,1987). Pedro Demo (1984), em seu artigo "Elementos metodológicos da pesquisa participante" coloca que

"é impossivel a Pesquisa Participante fora de uma postura dialética, sua forte crítica à pesquisa tradicional acaba coincidindo com a reivindicação de uma metodologia própria das ciências sociais, que não tenta imitar tacanhamente as ciências naturais" (Demo, 1984, p.112)

Freire (1986), em seu artigo "Criando Métodos de Pesquisa Alternativa: aprendendo a fazê-la melhor através da ação" coloca claramente algumas questões fundamentais para a reflexão:

"Considero importante, nesta altura de nossa conversa, insistir mais uma vez sobre o caráter político da atividade científica. A quem sirvo com a minha ciência? Esta deve ser uma pergunta constante a ser feita por todos nós. E devemos ser coerentes com a nossa opção, exprimindo nossa coerência na nossa prática.(...) Se é incoerente que um profissional reacionário, elitista, envolva os grupos populares como sujeitos de pesquisa em torno de 
sua realidade, contraditório também é que um profissional chamado de esquerda descreia das massas populares e as tome como simples objetos de seus estudos ou de suas ações "salvadoras"'(Freire, 1986, p.36)

Dentro dessa perspectiva, um artigo muito interessante e esclarecedor, que contextualiza a questão da vinculação entre ciência social e compromisso político dentro do processo histórico, especialmente entre as relações político-econômicas entre países do $1^{\circ}$ e $3^{\circ}$ mundo, nos foi dado por Bonilla et alli (1984)

Segundo Esteves (1987) as áreas de aplicação envolvem principalmente o Serviço Social, Educação, Comunicação, Organizações e Instituições, Desenvolvimento Rural, Saúde, Movimentos Sociais e outras áreas.

Michel Thiollent (1985), especificamente em relação à pesquisa-ação, discorreu sobre as áreas de aplicação dessa metodologia, particularmente em relação às áreas de educação, comunicação, serviço social, organização, tecnologia rural e práticas políticas, discutindo especificidades de cada uma dessas áreas. Trata-se de uma leitura interessante por dar uma noção do desenvolvimento da pesquisa em áreas distintas.

Em uma pesquisa realizada em setembro/outubro de 97 nos acervos informatizados disponíveis para consulta nas bibliotecas da Escola Superior de Agricultura "Luiz de Queiroz", em especial o CD-ROM "TREE-CD" existente na biblioteca do Instituto de Pesquisa Florestais - Departamento de Ciências Florestais, constatou-se que metodologias de pesquisa-participante vêm sendo utilizadas na área agricola e florestal majoritariamente em países ditos em desenvolvimento por agências de desenvolvimento/universidades de países de $1^{\circ}$ mundo. Os projetos envolvem basicamente iniciativas de "desenvolvimento sustentável" junto a comunidades rurais pobres (maiores detalhes em anexo).

A Internet também oferece uma rica fonte de referências que indica outras áreas de aplicação de metodologias de pesquisa participante, que vão desde a área educacional (estratégias de ensino, currículo), saúde (pesquisas envolvendo grupos de risco da AIDS), extensão universitária, arquitetura paisagística, inclusive a existência de redes de trabalho 
(networks) sobre action-research na área educacional, revistas especializadas, artigos abordando questões como história e epistemologia da action-research, eventos e muitos outros temas. Obviamente, é de se esperar que essa diversidade de abordagens inclua diferentes percepções, valores e fundamentações dessas pesquisas participantes, que podem variar desde uma visão mais positivista da ciência para propostas voltadas a transformações sociais, como predomina em nosso meio.

\subsubsection{Considerações Finais}

Esta revisão teve como principal intenção a de contribuir no aprofundamento da questão da participação enquanto perspectiva de pesquisa científica e construção do conhecimento. Procurou-se inserir a problemática da participação, seus pressupostos e princípios, sua inserção dentro do contexto das ciências sociais enquanto metodologia, suas várias interpretações e utilizações com base nos referenciais teóricos de análise e interpretação da realidade. As referências são essenciais para o aprofundamento dessas questões.

Uma importante etapa é atingida quando da apresentação dos resultados das pesquisas: a partir dos erros e acertos, do encontro das teorias e metodologias com os contextos de pesquisa de campo, das experiências vividas, criam-se novas oportunidades para o avanço da reflexão/ação das pesquisas ditas participantes nos campos da agricultura, floresta e meio ambiente. Relatar detalhadamente os métodos utilizados nessas pesquisas pode ser uma contribuição significativa para o avanço dessa área em nosso meio.

Finalmente, caberia colocar que a inserção da participação dentro do campo de atuação profissional de técnicos como agrônomos, florestais, biólogos ou ecólogos é uma necessidade premente dentro da busca de uma ciência voltada para o "mundo real" $\mathrm{e}$ "para aliviar a miséria da existência humana" (apropriamo-nos de trecho de poesia de Berthold Brecht).

\subsubsection{Uma análise do Curso}


O curso, após a aprovação nas instâncias ligadas à extensão universitária da USP, foi realizado em outubro de 1997 nas dependências do SESI - Serviço Social da Indústria, unidade de Votorantim. A estrutura e programação do curso foi a seguite:

“ CURSO DE DIFUSÃo CULTURAL “ÁREAS VERDES URBANAS, EDUCAÇÃO AMBIENTAL E CIDADANIA"

Promoção: Departamento de Ciências Florestais da Escola Superior de Agricultura "Luiz de Queiroz" - Universidade de São Paulo (USP)

Colaboração: SESI - Votorantim Associação de Moradores do Bairro Parque Bela Vista e Maria José Prefeitura Municipal de Votorantim

Docentes: Dr. Marcos Sorrentino (ESALQ/USP)

Eng. Florestal Adriano Lopes Pereira de Melo

Público-alvo: Lideranças comunitárias

Associações de Moradores

Sindicatos

Grupo Escoteiros

Clubes de Serviço

Público em geral interessado

Carga horária: 24 horas 
Local de Realização: Salão Nobre do Centro Educacional e Esportivo do SESI (Serviço Social da Indústria) - Votorantim - Avenida Cláudio Pinto do Nascimento $\mathrm{n}^{\circ} 140$ - Jardim Paraíso - Votorantim

Programação:

Quinta-feira, 02 de Outubro de 1997 - das 20:00 às 22:00 horas -Apresentação da Proposta do Curso, dos responsáveis e participantes -Problemas Ambientais Urbanos: definições e características -Espaços Livres de Uso Público: conceitos e tipologias

Sexta-feira, 03 de Outubro de 1997 - das 20:00 às 22:00 horas -Apresentação da Proposta de Trabalho de Campo: Diagnóstico Participativo de uma Área Verde

-Discussão e Formação dos Grupos de Trabalho -Programação das Atividades de Campo

Sábado, 04 de Outubro de 1997

-das 08:00 às 12:00 horas

-Trabalho de Campo: Diferentes Situações de Espaços Livres de Uso Público (Diagnóstico Geral)

-Início de Diagnóstico Participativo de uma Área Verde específica Estudo de Caso

- das 14: 00 às 18:00 horas

-Continuidade do trabalho de campo - Diagnóstico Participativo de uma Área Verde

-Organização e discussão dos Dados para Apresentação - Seminário 
Quinta-feira, 09 de Outubro de 1997 - das 20:00 às 22:00 horas

-Educação Ambiental e Participação: o papel dos cidadãos

-Os compromissos globais assumidos: Fórum de ONGs e Movimentos Sociais, Agenda 21, Agendas Locais

Sexta-feira, 10 de Outubro de 1997 - das 20:00 às 22:00 horas

-Política Municipal de Meio Ambiente: elementos, legislação, formas de implementação

- Formas de Participação em questões ambientais - formais e não formais

Sábado, 11 de Outubro de 1997

- das 08:00 às 12:00 horas

-Organização dos Seminários de Apresentação dos Grupos

-Síntese e Discussão Geral

-das 14:00 às 18:00 horas

-Apresentação e Debate: O movimento ambientalista e uma Área Verde do município de Votorantim

-Avaliação dos Participantes e do Curso

-Propostas de Encaminhamento e Continuidade" (Melo, 1997)

Foram convidados formalmente (convite por oficio) as seguintes entidades:

-Associações de Moradores de Votorantim (cerca de 20);

-Clubes de Serviço (Rotary e Lions);

-Ministério Público/Curadoria do Meio Ambiente da Comarca local;

-Diretoria do Cachoeira Futebol Clube;

-Diretoria do Sindicato dos Trabalhadores da Indústrias de Papel e Papelão; 
-Diretoria do Sindicato dos Trabalhadores da Indústria

Fiação e Tecelagem/Subsede Votorantim;

-Diretoria do Sindicato dos Trabalhadores das Indústrias da Construção e Mobiliário de Sorocaba-Sub-sede Votorantim;

-Diretoria do Sindicato dos Servidores Públicos Municipais;

-Associação Comercial, Industrial e dos Trabalhadores Autônomos de Votorantim;

-Associação dos Aposentados e Pensionistas de Votorantim;

-Imprensa local e regional : Folha de Votorantim, Jornal de Votorantim, Jornal Cruzeiro do Sul e Diário de Sorocaba;

-Equipe de Educação Ambiental do Parque do Matão.

Além desses convites formais, na divulgação feita pela imprensa foi feito um convite para o público em geral interessado.

Foram feitas 22 inscrições de pessoas interessadas, sendo que receberam o certificado de participação (mínimo de $70 \%$ de freqüência) 15 participantes. Alguns inscritos não compareceram.

Desses participantes, dois eram membros do Grupo Escoteiro "Vuturaty", três componentes da equipe de Educação Ambiental do Parque do Matão, uma arquiteta do Núcleo Sorocaba do IAB - Instituto de Arquitetos do Brasil, uma ex-integrante do Grupo Ecológico Cascata Branca, três integrantes da Associação de Moradores do Bairro Parque Bela Vista, um integrante da Associação dos Aposentados de Votorantim, um integrante do Sociedade Amigos do Bairro Green Valley e três participantes não vinculados a nenhuma entidade. Portanto, das cercas de 35 entidades convidadas formalmente (oficio, considerando separadamente as Sociedades Amigos de Bairro), apenas 03 participaram.

O curso estruturou-se de forma a estimular a participação, principalmente em atividades de Grupo, em todos os assuntos abordados, havendo alguns momentos mais expositivos por parte dos idealizadores do mesmo, como uma explanação sobre áreas verdes urbanas e política municipal de meio ambiente, por meio de slides e retro-projetor. 
Utilizou-se de recursos como a tea tralização, troca de papéis e outras técnicas de dinâmica de grupo na condução dos trabalhos.

Entre as atividades práticas programadas, incluiu-se um dia de campo com a realização de observações sobre diferentes situações de áreas verdes urbanas (praça implantada e com boa manutenção, praças implantadas sem manutenção e áreas públicas invadidas para fim de moradia), no período da manhã, e um trabalho mais detalhado na área da cachoeira, sendo que os alunos deveriam apresentar um seminário com os dados levantados para subsidiar a discussão final do curso, antes da apresentação de todo o histórico sobre a movimentação em torno da área da cachoeira feita pelo Grupo Ecológico Cascata Branca.

Os participantes foram divididos em 03 grupos de em média 05 componentes, aos quais foi distribuído um roteiro de trabalho de campo com orientações básicas, bem como filmes para registrar os pontos de interesse por parte dos participantes e fitas para gravação de depoimentos, principalmente no trabalho mais sistemático na área da Cachoeira. Pode-se considerar que esse trabalho foi uma tentativa de realização de um "Diagnóstico Rápido Participativo" da área, buscando subsídios para o trabalho de pesquisa do autor, inserido dentro do contexto mais amplo da problemática ambiental urbana e da participação dos cidadãos e poder público. Cabe destacar que em nenhum momento do curso foi colocado que seriam colhidos para a pesquisa do autor. O objetivo principal do mesmo foi o de contribuir para a formação dos participantes interessados na problemática das áreas verdes urbanas.

Em relação especificamente a prática de campo realizada na área em várias situações de áreas verdes (período da manhão do dia 04/10/97) e na área da Cachoeira (período da tarde do dia 04/10/97), os participantes foram divididos em três grupos e munidos de material para anotações, gravador e máquina fotográfica fizeram observações, a partir de um roteiro básico de orientação: 


\section{"ROTEIRO DE TRABALHO DE CAMPO}

1. VISITA A DIFERENTES SITUAÇÕES DE ÁREAS VERDES

1.1 PARADA 01

DENOMINAÇÃO: PRAÇA SENADOR JOSÉ ERMÍRIO DE MORAES

SITUAÇÃO:

O QUE PODERIA SER FEITO:

1.2 PARADA 02

DENOMINAÇÃO: PRAÇA RUA JOSÉ TOMAZ DA COSTA/CELSO MIGUEL DOS SANTOS

SITUAÇÃO:

O QUE PODERIA SER FEITO:

1.3 PARADA 03

DENOMINAÇÃO: SISTEMA DE LAZER FINAL RUA ENRICO VIOLINO SITUAÇÃO

O QUE PODERIA SER FEITO

1.4 PARADA 04

DENOMINAÇÃO: PRAÇA DOS EXPEDICIONÁRIOS

SITUAÇÃO

O QUE PODERIA SER FEITO

1.5 PARADA 05

DENOMINAÇÃO: ÁREA VERDE (SISTEMA DE LAZER) INVADIDO PARA FINS DE MORADIA AO LADO DA ESCOLA DO PARQUE MORUMBI/PARQUE BELA VISTA

SITUAÇÃO

O QUE PODERIA SER FEITO 
ESTUDO DE CASO - ÁREA DA CACHOEIRA

ROTEIRO DE OBSERVAÇÃO

1. MEIO FÍSICO E BIÓTICO

- VEGETAÇÃo : NATIVA , PLANTADA, ÁREAS COM VEGETAÇÃO RASTEIRA,

DISTRIBUIÇÃO, LOCALIZAÇÃO

LOCAIS QUE DEVEM SER REFLORESTADOS

PAISAGISMO

- CURSOS D' ÁGUA: LOCALIZAÇÃO, SITUAÇÃO - POLUIÇÃO (TIPO, INTENSIDADE)

- SOLO: LOCAIS COM EROSÃO, AFLORAMENTOS DE ROCHA, DESLIZAMENTOS

- FAUNA: OCORRÊNCIA DE ANIMAIS E AVES SILVESTRES NO LOCAL, POTENCIAL DA ÁREA COMO ABRIGO DA FAUNA, RESGATE HISTÓRICO-QUE ANIMAIS E AVES OCORRIAM NO LOCAL, NECESSIDADES E POSSIBILIDADES DE RECUPERAÇÃO

2. OCUPAÇÃO HUMANA

-CONSTRUÇÕES NO LOCAL: TIPO, DIMENSÕES (APROXIMADAS), FINALIDADE, ADEQUAÇÃO AO LOCAL

- USOS DIVERSOS NO LOCAL: AGRICULTURA, PASTAGEM, QUINTAIS, HORTAS (PARA SUBSISTÊNCIA E/OU COMERCIALIZAÇÃO) -OCUPAÇÕES: TEMPO QUE ESTÃO NO LOCAL

-PROBLEMAS OCASIONADOS PELAS OCUPAÇÕES: LIXO, ESGOTO, RETIRADA DA VEGETAÇÃO, QUEIMADAS E OUTROS 
- USOS PARA ATIVIDADES ESPORTIVAS E DE LAZER/RECREAÇÃO: TIPO E CARACTERISTICAS DAS ESTRUTURAS, ADEQUAÇÃO AO LOCAL, PROBLEMAS OCASIONADOS POR ESSAS ATIVIDADES, BENEFÍCIOS

\section{PERCEPÇÕES DOS MORADORES DO ENTORNO}

- MORADORES ANTIGOS: HISTÓRIA DO LOCAL (RESGATE HISTÓRICO), COMO ERA USADO, COMO ERA ANTES (AMBIENTE), QUE MUDANÇAS OCORRERAM, SE AINDA FREQUENTAM O LOCAL, QUE PROBLEMAS EXISTEM, COMO A ÁREA PODE SER MELHORADA, INTERESSE EM PARTICIPAR DA ELABORAÇÃO DE UMA PROPOSTA PARA O LOCAL

- MORADORES ATUAIS: COMO A ÁREA ESTÁ HOJE, SE ESTÁ SATISFEITO COM A ATUAL SITUAÇÃO, O QUE PODERIA SER FEITO PARA MELHORAR, PROBLEMAS EXISTENTES, SE FREQÜENTA O LOCAL E DE QUE FORMA, DISPOSIÇÃO DE PARTICIPAR NA ELABORAÇÃO DE PROPOSTAS E ATIVIDADES NO LOCAL

4. FREQUENTADORES DO LOCAL

- HÁ QUANTO TEMPO FREQUENTA, PORQUE FREQUENTA, SE EXISTEM PROBLEMAS NO LOCAL (QUAIS E SUAS CAUSAS), OPINIÕES SOBRE A SITUAÇÃO DA ÁREA E O QUE PODE SER MELHORADO, COMO UTILIZA A ÁREA (PASSEIO, NATAÇÃO, CHURRASCOS), PONTOS PRINCIPAIS DE INTERESSE. “(Melo, 1997)

Os dados foram trabalhados pelos Grupos, que apresentaram Seminários no último dia do Curso. Em relação à área da Cachoeira, cada grupo ficou responsável por um item/tema, sendo que um dos grupos ficou responsável por dois temas correlatos: Percepção de moradores do entorno e dos frequentadores do local. 
Apesar do pouco tempo disponivel para a atividade e do objetivo didático, os resultados e discussões efetuados foram bastante motivadores, muito em função do interesse dos participantes que efetivamente se empenharam nas atividades, de forma geral.

Os resultados dos trabalhos práticos desenvolvidos foram muito ricos $\mathrm{e}$ propiciaram um debate interessante sobre toda a problemática das áreas verdes urbanas a partir da realidade encontrada. Foi gerado materiais como depoimentos de moradores da área da cachoeira e frequentadores do local sobre a própria área (cerca de 03 horas de entrevistas gravadas), seus problemas e potencial, bem como a visão dos mesmos sobre o relacionamento da Prefeitura com a área, entre outras questões.

Os grupos apresentaram os resultados - o Seminário - na forma de cartazes, painéis e apresentação verbal para os demais participantes.

Em relação à situação da área da Cachoeira:

-Meio Físico:

“-moradores dentro da área de preservação

-desmatamento e degradação provocados por um curral

-lanchonete fora dos padrões

-Queimadas

-Esgoto/ Córrego/ Lixo

-Desmatamento para plantação"

Em relação às propostas de melhoria e implantação do Parque:

“ - Construção do Parque da Cachoeira, levando em consideração a realidade atual da área, com atividades de preservação, pesquisa, lazer, educação ambiental, turismo, gerando emprego para os moradores locais.

- Ação do Poder Público em relação aos problemas de esgoto e lixo no local

-Reconstituição da Mata Ciliar

-Retirada das Invasões

-Revisão e implantação de um projeto para o Parque 
-Processo de Implantação: Mutirão, Campanhas publicitárias, Verba de Iniciativa privada e Prefeitura, Participação dos Moradores ao redor do Parque"

- Aproveitamento dos moradores como mão-de-obra na estrutura do Parque da Cachoeira

-Manutenção das estruturas, com melhorias, para uso dos frequentadores do Parque e moradores do Bairro (Esporte Clube Cachoeira) -Educação Ambiental para os frequentadores e moradores".

Destacamos entre as entrevistas, os seguintes depoimentos:

"Grupo: Como o sr. vê a área junto ao campo ao lado da cachoeira? Cite alguns problemas que considera mais graves.

Entrevistado: $O$ problema mais grave é a poluição no rio Sorocaba, problema este que já foi até motivo de reportagem de jornais e televisão. Havia no passado um grande volume de água no leito desse rio, e água limpa sem poluição, quando moço jogávamos futebol num campo menor que existia aqui e logo após os jogos tomávamos banho de rio, hoje você pode notar que com a diminuição da quantidade de água e os bancos de areia isso se tornou impossivel.

Grupo: Existia alguma mata aqui maior do que existe ou a paisagem que nós vemos foi sempre esta?

Entrevistado: Havia sim mais árvores, no lugar do campo (do clube cachoeira), havia um enorme lago que deu lugar ao campo, com o fechamento da fábrica de papel celulose (Votocel) a poluição da água diminuiu mas hoje deparamos com o lixo e o esgoto vindos do morro no final da vila Amorim" (Morador do bairro, 48 anos) 
Nessa entrevista, temos o relato da situação da área da cachoeira há décadas atrás, onde existia uma grande várzea e lago que foram aterrados para a implantação do campo de futebol.

Também foi entrevistado o presidente do Cachoeira Futebol Clube, equipe tradicional de futebol de várzea da cidade que tem sua sede e campo na área, onde o mesmo também se recorda da abundância de peixes, da poluição gerada pela fábrica Votocel e que observou um aumento na freqüência de usuários. Destacou também, ao ser questionado sobre o que poderia ser feito para melhorar a área, a importância histórica da mesma e a falta de preocupação das "autoridades".

Entrevistaram também um assíduo freqüentador do local, que segundo o mesmo “é o melhor espaço de lazer que nós temos aqui"(Entrevistado, 17 anos) e sugeriu a melhoria do acesso e segurança devido ao aumento da marginalidade nas imediações.

Dentre as observações gerais dos freqüentadores citadas pelo Grupo, incluíram-se a necessidade de recuperação (iluminação e cobertura) da quadra esportiva existente próxima a cachoeira (construida da gestão do prefeito "Zeca Padeiro"), a necessidade de regras para visitação, feita de forma desordenada e colocando em risco a preservação da área, necessidade de sensibilização das autoridades para o reconhecimento do valor natural e concretização de um projeto para a área e a pouca importância dada ao valor histórico do bairro da Chave.

Outros dado muito relevante obtido por outro Grupo envolveu entrevistas com moradores da área. Como já citado anteriormente, a área destinada ao parque da cachoeira possui cerca de 10 hectares, sendo a maior parte dos mesmos encostas, sendo que anteriormente ao processo de desapropriação já existiam várias ocupações na área. Portanto, qualquer iniciativa de implantação deveria considerar esse fato.

Foram entrevistados cerca de 04 moradores, sendo que uma familia alega que se encontra na área há 43 anos. Segundo estes, a área, ocupada hoje com intensa arborização (frutiferas principalmente), antes era "limpa"(gramíneas). Antigamente pescavam camarão no córrego Itapeva, que hoje concentra todo o esgoto doméstico de áreas a montante. Informaram que já houve foram procurados pela Prefeitura para desocupar a área, sem acordo. 
Outro morador alega que está na área a 25 anos, com processo de usucapião, sendo que seu barraco foi feito pela Prefeitura. Mantém uma pequena roça de subsistência.

Foi entrevistado uma moradora em cuja área existe um grande bananal, situado na foz do córrego Itapeva. O marido vende as bananas na feira. Alegam estar na área a 12 anos. Demonstrou não ter muito interesse em passear na área da cachoeira:

" a gente que mora aqui não tem muita paixão por isso, agora tem gente que vem de longe e vê, atrai né, a gente já ta acostumado".

Outra moradora entrevistada alega morar na área a 9 anos, e disse que, curiosamente, nunca foi visitar a cachoeira:

"Só que conheço só de vista, porque para dizer para vocês lá mesmo eu nunca fui, por aqui até que vai, chega perto, porque é que tem esgoto que tem que atravessar e o rio também. $O$ certo mesmo é passar pela Chave, para poder ir lá pertinho".

Essa moradora fora sorteada no programa de habitação popular da Prefeitura, e temia que com sua saída a área pudesse ser invadida. Adquiriu seu barraco de morador vizinho que está na área há mais de 40 anos.

Entre as conclusões dos participantes do curso, chegadas após discussões no Seminário, tivemos:

1. A elaboração de um documento com um resumo do que foi feito para ser divulgado junto ao Prefeito, Câmara de Vereadores e Imprensa;

2. A formação de uma comissão, com um representante de cada entidade participante, para o encaminhamento das propostas apresentadas no curso;

3. O interesse na realização de novos cursos com a temática ambiental.

Após a realização do Curso, tentou-se dar continuidade aos trabalhos no ano de 1998, através da tentativa de criação de uma nova entidade ambientalista. Realizaram-se várias reuniões na sede do Parque do Matão e do Centro Comunitário do Parque Bela Vista ,onde foi definida a criação da entidade intitulada "Ação Cidadania e Meio Ambiente", que chegou até a organizar a apresentação na forma de painéis de suas propostas na forma de painéis dentro de um evento da cidade, a Expo-Verde de 1998. 
Porém, não foi dado continuidade ao Grupo em função principalmente do fato de seus participantes já estarem envolvidos com outros grupos, como Associação de aposentados, Associação de Moradores, Administração do Parque do Matão, grupo escoteiro e outros, entre os quais o próprio autor.

Caberia esclarecer que a participação da Prefeitura nesse curso restringiu-se a cessão de um ônibus para as atividades do dia de campo e do material de apoio (retroprojetor e projetor de slides), conseguidos através da intermediação de um colaborador da Associação de Moradores de um bairro com acesso ao Secretariado e Gabinete do Prefeito. Este último, assim como seus assessores (Secretariado) também foram convidados para participar, porém não houve interesse de nenhum funcionário da Prefeitura além do próprio autor.

Dessa experiência tiramos alguns indicativos sobre a potencialidade do uso de baseadas em metodologias participativas de diagnóstico de problemas ambientais urbanos, dentro dos princípios do Diagnóstico Participativo Rápido Rural (DRR) expostos por Whiteside (1994)

Segundo Whiteside (1994), o Diagnóstico Rápido Rural (DRR ou RRA em inglês) e o Diagnóstico Rápido Rural Participativo (DRRP ou PRRA em inglês) consistem

"(...) em um conjunto de técnicas para a recolha de informação que podem ser usadas por projectos em desenvolvimento, para descobrir as principais características, os problemas prioritários que afectam a população e as possiveis soluções dentro da comunidade" (Whiteside, 1994, p. 04).

Whiteside (1994) observou que essas técnicas, embora sejam desenvolvidas em áreas rurais também tem sendo usadas com sucesso em muitas áreas urbanas de outros países. Gomes (1999, informação pessoal) citou que vem aumentando o interesse na utilização dessas técnicas no estudo de extrativismo florestal em comunidades rurais, tendo a mesma sido covidada a ministrar um curso sobre o tema. Consultando a bibliografia, não obtivemos nenhum registro do uso dessa técnica no estudo de problemas ambientais urbanos no Brasil. 
As técnicas de DRP, segundo Whiteside (1994) são resumidamente:

-Revisão de dados secundários; no caso do trabalho de campo os participantes receberam ao longo do curso uma série de informações de interesse a respeito da questão das áreas verdes urbanos, legislação e outro;

-Observação direta; posta em prática no trabalho de campo na área da cachoeira;

-Entrevistas semi-estruturadas; feitas pelas equipes com os moradores do local, do entorno e freqüentadores da área;

-Discussões em Grupo; prática utilizada em todo o curso;

-Diagramação; técnica utilizada para discutir as relações entre o indivíduo, o poder público e a questão ambiental, onde por meio de círculos foi feita uma representação sobre as interações entre os mesmos;

-Mapeamento e modelação participativos; cada equipe do trabalho de campo teve disponivel para o trabalho de campo um mapa em escala 1: $1.000 \mathrm{da}$ área onde representaram a situação atual da mesma e apresentaram o mapa no Seminário final do curso, resultados muito interessantes;

-Ordenamento (indicar preferências e porque as pessoas fazem certas escolhas), não aplicado no trabalho de campo;

-Quantificação local, mais utilizada no estudo em áreas agrícolas;

-Jogos e representações; utilizadas ao longo do curso, citando apenas como exemplo na discussão introdutória sobre as áreas verdes urbanas, onde cada grupo ficou responsável por representar um interesse dentro do contexto problemático da ocupação para fins de moradia existente em Votorantim: um grupo representou o lotedor clandestino, outro o vereador que apoiava a invasão, outro os moradores do entorno da área invadida, outro a Prefeitura, com ótimos resultados para a compreensão da dinâmica e complexidade da questão;

-Histórias, retratos e citações; também utilizados, no trabalho de campo na área da cachoeira cada grupo recebeu um filme para registrar imagens de interesse;

-Seminários; no caso a etapa final do curso;

-Relatórios de retorno à comunidade, não realizado devido ao caráter pontual do curso. 
Portanto, a realização do curso serviu para demonstrar :

1. A complexidade da situação da área objeto de estudo e destinada a implantação do Parque da Cachoeira, como as ocupações antigas existentes que inclusivem são a fonte de renda da alguns moradores, os pontos de maior degradação ambiental, as percepções dos usuários e moradores do entorno e as relações existentes entre os mesmos e a área.

Citamos como exemplo que o projeto realizado por uma empresa particular em 1995 previu a desativação do campo de futebol existente na área bem como a sede do Cachoeira futebol Clube, que certamente encontrará muitas resistências devido a antiga relação entre tal Clube e a área, bem como não realizou um diagnóstico sobre a ocupação e problemas existentes.

2. A potencialidade do uso de técnicas participativas no diagnóstico e implantação de espaços livres de uso público dentro de uma perspectiva de participação e educação ambiental, que não foi compreendida e apoiada pelo poder público local.

3. As limitações pela pouca experiência acumulada da aplicação dessas técnicas em nosso meio são uma séria limitação a ser observada, mas que longe de serem enxergadas como obstáculos devem servir como estímulo para o aprofundamento no estudo e aplicação das mesmas. 


\section{CONSIDERAÇÕES FINAIS}

Por um percurso tortuoso, procuramos ao longo desta Dissertação buscarmos respostas aos questionamentos a respeito do papel das pequenas entidades ambientalistas, a possibilidade da implantação de espaços livres de uso público servir como um instumento de Educação Ambiental e ao papel do Poder Público nesse contexto.

Longe de conseguirmos respostas absolutas e verdades inquestionáveis, tendo em vista a própria complexidade dos fenômenos estudados e do aparato limitado de pesquisa, obtivemos indicativos fortes que estimulam o desenvolvimento de novas pesquisas e a continuidade da busca um conhecimento voltado para a solução de problemas ambientais tão presentes na realidade cotidiana brasileira e que acompanham o autor desde seu envolvimento com a questão ambiental.

Entre esses indicativos, destacamos inicialmente a potencialidade de técnicas de Diagnóstico Rápido Participativo no estudo e busca de soluções para problemas ambientais urbanos, dentro de um espírito de construção conjunta do conhecimento e postura dialógica entre os idealizadores dessas intervenções e o público-alvo. Apesar das limitações observadas principalmente em relação à falta de experiência e referências de uso em situações similares, essa perspectiva metodológica se apresenta como tendo um grande potencial para o desenvolvimento dentro da área ambiental e mesmo florestal.

Concluímos sobre a relevância do papel de pequenas entidades ambientalistas como o Grupo Ecológico Cascata Branca, que apesar da não-institucionalização e carência de estrutura material, firmou-se como um local privilegiado para o autoconhecimento, para a construção de um visão crítica, para o fortalecimento da cidadania e para a inserção dos valores ambientalistas nos indivíduos e comunidade local.

Isso indica a necessidade de melhor estudar essas pequenas entidades, por meio de estudos comparativos ou por meio de Estudos de Caso, pois essas pequenas entidades são ainda a maioria e geralmente pouco valorizadas, até ridicularizadas na grande imprensa como os "eco-chatos" em casos mais graves de desinformação e crítica destrutiva, em contraposição as chamadas "King-ONGs" como a SOS Mata Atlântica, 
Fundação Biodiversitas, GreenPeace e outras, entidades com história consolidada e estrutura (material, humana, financeira), com grande acesso e circulação na mídia, profissionalização e inclusive até esquemas de marketing e royalties da sua "marca".

Dentro desse contexto, a Universidade deve continuar oferecendo subsidios para o estabelecimento e consolidação dessas pequenas entidades, seja através da participação direta de alunos como o caso estudado seja por oferecer oportunidades de aprofundamento nas questões ambientais e mesmo organizacionais por integrantes dessas entidades, dentro de propostas de Extensão Universitária ou mesmo desenvolvimento de projetos e parcerias tendo como base metodologias participativas.

Sorrentino (1995) destaca que, segundo alguns autores, a Universidade é um local importante para a formação de recursos humanos e para servir de apoio na construção de sociedades sustentáveis. Também Sorrentino (1995) coloca que o compromisso da Universidade com a transformação da sociedade possibilitando igualdades de condições a todos os seres humanos é uma antiga reivindicação de inúmeros movimentos sociais.

A complexidade das relações com o Poder Público local com a entidade analisada, que muitas vezes pode ser configurada como um conflito, na realidade se configura como um reflexo na devida escala local da imagem de como formadores de opinião na área ambiental vêem o Estado, conforme o estudo feito por Crespo \& Leitão (1993):

“" O Estado e o Governo brasileiros desfrutam de uma imagem bastante negativa entre os formadores de opinião, até mesmo entre os técnicos governamentais e setores da intelligentsia em seus aparelhos culturais (por exemplo, as universidades). É como se, independentemente dos agentes/dirigentes, a "máquina governamental" se movesse segundo uma lógica própria, resistente a governos e políticas (...) A maior parte dos entrevistados referiu-se à dificuldade de se introduzirem mudanças na máquina "viciada"e "emperrada" do Estado. Quer seja considerado em sua esfera municipal, estadual ou federal, o Estado brasileiro é tido como "um organismo doente, obsoleto, cada dia mais incapaz de responder às 
demandas da sociedade brasileira"(Crespo \& Leitão, 1993, p. 130131).

Apesar das devidas ponderações a respeito das consequiências nefastas do rápido processo de urbanização pelo qual cidades como Votorantim passou, onde o Poder Público se viu com sua atenção voltada para questões relativas ao atendimento de necessidades básicas da população como saúde, educação, segurança, observamos que o Poder Público local não tem incorporado a questão ambiental como uma componente das Políticas Públicas.

Questões complexas como opiniões e visões pessoais sobre a própria existência e magnitude de problemas ambientais por parte de Prefeitos, além de questões como falta de recursos específicos, problemas "políticos" advindos das peculiaridades da cultura política provinciana, falta de interesse, ausência de corpo técnico específico e principalmente a falta de vontade política têm inviabilizado a criação e implantação de uma política ambiental municipal em Votorantim.

Essa situação de total desarticulação e falta de uma política ambiental, que perdura mesmo após os cerca de 06 anos em que o autor passa a integrar o corpo técnico da Prefeitura, onde cessam as pressões e mobilizações de fora da estrutura administrativa, mostra a necessidade da importância da existência e do papel propositivo das entidades ambientalistas e seu papel crítico a ser cumprido. Porém, devem haver avanços na busca de um possível diálogo do movimento ambientalista com outros movimentos sociais para aumentar a legitimidade da pressão, bem como abrir a possibilidade de aberturas de parcerias. Ferreira (1998) nos mostrou resultados positivos no avanço na implantação de políticas ambientais municipais, embora alguns exemplos também tenham mostrado que mesmo em governos nos quais o discurso se mostravam como um nova proposta mais voltada aos anseios da população, ocorreram sérias dificuldades que em alguns casos inviabilizaram qualquer tentativa de implantação de uma política ambiental.

Novas experiências práticas e implicações teóricas de tendências administrativas vêm sendo estudadas, indicando sobre a necessidade do repasse de mais recursos para o nível local, mas também a necessidade de deixar a sociedade gerir-se de forma mais 
flexível, segundo as características de cada município, passando pela criação de mecanismos participativos simplificados e mais diretos dos atores-chave das cidades: empresários, sindicatos, organizações não-governamentais, instituições cientificas e outros, passando também pela necessidade da criação de mecanismos de comunicação mais ágeis com a população (Ferreira, 1998).

Dentro dessa perspectiva é que voltamos a destacar o papel educacional das pequenas entidades ambientalistas, que através da sua luta cotidiana pela melhoria do ambiente local pode contribuir para a busca da tão almejada sustentabilidade econômica, política, social e ambiental do nosso ambiente imediato - as nossas cidades. 
ANEXO 01

Uma pesquisa feita pelo autor em setembro de 1997 em vários catálogos informatizados internacionais de referências bibliográficas ou "abstracts" (disponíveis para consulta na biblioteca do IPEF -Departamento de Ciências Florestais da ESALQ/USP) especificamente nas áreas de ciências florestais dão panorama bastante amplo da aplicação das metodologias de pesquisa participantes nessas áreas.

$\mathrm{Na}$ Biblioteca Central da ESALQ também existem computadores com CD-ROMs de "abstracts" para a área de agricultura. Utilizando palavras-chaves (action-research, participatory-research) e vários bancos de dados (CAB Abstracts 72/96, TROPAG \& RURAL 75/96, AGRIS 75/88 e FSTA 69/96) encontram-se mais de 900 artigos resumidos relatados, mas o presente trabalho reteve-se no TREE-CD, mais voltado para a área florestal, tendo em vista o objetivo de apenas dar uma noção superficial do "estado da arte" dessas pesquisas pelo mundo.

\section{TREE-CD}

Trata-se de um catálogo em CD-ROM com milhares de dados de interesse para a área florestal. Por meio de palavras-chave (em inglês), têm se acesso aos resumos de artigos e publicações variadas, indexadas desde 1973 e permanentemente atualizadas. A busca deu-se através das seguintes palavras-chave: action-research, participatoryresearch, participation e social-participation.

A primeira busca (action-research), resultou em apenas 05 trabalhos indexados, sendo que os trabalhos, bastante recentes (a partir de 1993) referem-se a projetos desenvolvidos principalmente por Centros de Pesquisa e Agências de Desenvolvimento de países de $1^{\circ}$ mundo (Suíça e Bélgica) em países do $3^{\circ}$ mundo, no caso África (Nigéria, Etiópia) e Ásia (Bangladesh). Dentre esses trabalhos, destacaria a publicação "Nongovernamental organizations and the State in Africa: rethinking roles in sustanable agricultural development", publicado na Inglaterra em 1993, com destaque para o artigo "Development of participatory approaches for promoting agroforestry: collaboration 
between the Mazingira Institute, ICRAF, CARE-Kenya, KEFRI and the forestry departament (1980-91), de BUCK et alli.

Este artigo discorre sobre o processo de institucionalização de abordagens participativas na promoção da agrosilvicultura no Kenia durante um período de 11 anos, com destaque para a atuação de uma pequena ONG nesse processo. Embora o acesso apenas ao resumo do trabalho ("abstract") não permita uma visão aprofundada do desenvolvimento e fundamentos da pesquisa, é possível ter uma visão do "estado da arte" das pesquisas participantes nessas áreas.

A segunda busca, participatory-research, não constou nenhum trabalho indexado. Já a terceira palavra-chave, participation, resultou em 323 trabalhos indexados. Tais trabalhos envolvem desde publicações do Banco Mundial referente ao desenvolvimento de políticas florestais em paises em desenvolvimento, como "Technologies related to participatory forestry in tropical and subtropical countries", contido no World Bank Tecnhical Paper $\mathrm{n}^{\circ}$ 229, de 1995, passando por abordagens mais teóricas como "People's participation in development projects-A critical review of current theory and practice", de Oxford (Inglaterra - Occasional Papers International NGOs Training and Research Centre, 1995), até manuais de campo, como 'Field method manual, Vol.II, Community forest economy in use paterns: Participatory Rural Appraisal (PRA) methods in South Gujarat, India", de 1992, publicação da "Society for Promotion of Westelands Development, de Nova Deli, Índia.

Essa diversidade de abordagens e linhas de trabalho tem alguns pontos interessantes em comum: utilização quase que total em países tropicais ditos "em desenvolvimento", participação significativa de agências de desenvolvimento de países "desenvolvidos", como Fundação Ford, a própria ONU (Organização das Nações Unidas através da Food and Agricultural Organization-FAO) e a Overseas Development Institute (ODI), da Inglaterra, entre outras. É também significativo o número de Universidades e Centros de Pesquisas de países do $1^{\circ}$ mundo envolvidos nessas propostas, citando alguns deles: Universidade de Wageninten, da Holanda, Centro Internacional de Desenvolvimento Rural da Universidade de Ciências da Agricultura da Suécia e Universidade de Michigan, por exemplo. 
$\mathrm{Da}$ "passagem de olhos" por esses resumos, outras considerações são pertinentes. Existem vários termos que são utilizados nessas abordagens, alguns deles pouco conhecidos (ou divulgados) no nosso meio, como por exemplo community forestry (silvicultura comunitária), social forestry (silvicultura social), joint forest management (manejo florestal coletivo ou associado), dentre outros. Quais os motivos desse relativo desconhecimento? É óbvio que não temos respostas. Mas o fato de que poucas pesquisas deste tipo foram relatadas na América Latina e nenhuma no Brasil leva-nos à uma reflexão sobre esses motivos. Durante a graduação em Engenharia Florestal (pelo menos durante a graduação feita pelo autor deste artigo, de 1986 a 1991) esses termos eram pouco abordados. Parece que no Brasil a temática da participação (no setor da agricultura e floresta), dentro da ótica da pesquisa-participante e suas vertentes, não foi explorada e ainda está dando seus primeiros passos, em comparação com outros países. Daí a importância das iniciativas e projetos que estão sendo desenvolvidos por alunos da pós-graduação, conforme citado no início do presente artigo.

Para quem pretende se aprofundar mais nas pesquisas participantes e similares na área florestal e sistemas agroflorestais, a relação dos 323 "abstracts" indica algumas fontes interessantes, principalmente periódicos, como o Indian Forester, Unasylva (especial issue-forestry extension,1996, $n^{\circ} 47$ ), Agroforestry today, Ambio, Agroforestrysystems, Forest,tree and people newsletter, Indian journal of forestry.

A última busca no TREE-CD utilizou a palavra-chave social-participation. Foram listados 88 resumos, alguns deles já contidos na listagem anterior. Destacaria resumos como "Participation, indigenous knowledge and trees", da Universidade de Cochabamba, na Bolivia, onde utilizaram-se metodologias de pesquisa participativa como a pesquisaação, diagnóstico rápido participativo, entrevistas e outros, na tentativa de introdução de técnicas agrossilviculturais. O interessante é que, segundo os autores, o trabalho demonstrou a necessidade da participação comunitária no sucesso na adoção dessas práticas, após uma tentativa fracassada "convencional" (não-participativa) de tentativa de introdução dessas técnicas.

Merecem destaque também publicações do Programa FTP (Forest, Trees and People) da FAO, como "Community forestry: participatory assesment, monitoring and 
evaluation" (FAO-Community forestry Note, 1989, vol.2), onde coloca-se que "há um reconhecimento crescente que a participação da população rural nos processos de desenvolvimento é de importância crucial". O trabalho então aborda os conceitos, abordagens e técnicas que fazem parte de uma estratégia de desenvolvimento participativa.

$\mathrm{Na}$ mesma linha, temos "Participatory research in agroforestry: learning from experience and expanding repertoire", contida na revista Agroforestry-System n ${ }^{\circ} 15$, de 1991, como resultado do Workshop "Methods for participatory on-farm agroforestry research", ocorrido em Nairóbi, Kenia, em 1990, e "Pratical participation", de SUMBERG et alli, publicação da Intermediate Technology Publications, Inglaterra, com uma série de artigos abordando a participação de agricultores em pesquisa nos países em desenvolvimento.

Trabalhos envolvem participação em reabilitação de áreas degradadas, como "Rehabilitation of degrated lans in the Hymalaian foothills: peoples participation", da Índia (revista AMBIO $\mathrm{n}^{\circ} 19,1990$ ), em manejo de bacias hidrográficas ('Farmer's participation and socio-economic effects of a watershed management programme in Central Java", publicado na revista Agroforestry-Systems n³, 1985, entre muitos outros. $O$ interessante é que existem trabalhos que se propõem a refletir sobre o próprio processo de participação como "How participatory is participatory development? Some lessons from Phillipines experience", de CASTILLO, apresentado no Workshop "Integrated rural development-concepts and experiences", ocorrido em Bonn, Alemanha, em março de 1985. No caso, o autor faz uma revisão sobre os conceitos da abordagem participativa no desenvolvimento de projetos em agrossilvicultura e irrigação nas Filipinas, colocando que a população rural pobre não teve ganhos significativos com essas abordagens de pesquisa.

$\mathrm{O}$ autor deste artigo tem especial interesse na aplicação de metodologias participativas em problemas ambientais urbanos, especificamente no desenvolvimento de estratégias de participação de setores da população no diagnóstico e concepção de projetos de espaços livres de uso público. Não se encontraram referências no TREE-CD com as palavras-chaves anteriores. Porém, na palavra-chave urban-parks, onde 
encontramos 64 referências, uma delas era bastante interessante, "Turning a new leaf", de Walker, publicado na revista Leisure-Manager $n^{\circ} 13$, de 1995. Tal projeto foi desenvolvido pelo Departament of the Environment em quatro municípios britânicos (Sandwell, Dudley, Walsall e Wolverhampton), no ano de 1988, em uma área florestal de 10 hectares, com o envolvimento das comunidades em todos os estágios de tomadas de decisão, planejamento, design e implementação. Embora não cite metodologias de pesquisa participantes, o fato de envolver a comunidade nessas etapas merece destaque.

\section{INTERNET}

Segundo a própria WEB, uma pessoa, ficando dez horas por dia acessando uma página por minuto, levaria quatro anos e meio para acessar um milhão de páginas, e a vida inteira seria pouco para acessar todas as informações disponiveis. Trata-se portanto de uma fonte de informações e intercâmbio inesgotável e em expansão extremamente rápida. Foram realizadas buscas preliminares em dois instrumentos de pesquisa internacionais ("searchers")- "Yahoo" e "AltaVista".

\section{Yahoo}

Utilizando a palavra-chave action-research, foram encontrados 25 matches, porém a maioria deles continham as palavras action e research não ligadas e em outro contexto, ou seja, não relacionados a pesquisa-ação enquanto metodologia de pesquisa. Porém, alguns matches a princípio continham trabalhos de interesse, merecendo ser citados:

- West Philadelphia Landscape Project - action-research research integrating research, teaching and community service.

Pesquisa-ação em projetos de arquitetura paisagística, área ainda não encontrada em referência a metodologias participativas 
- East St. Louis Action-Research Project - cooperatively managed assistance and development program of University of Illinois at Urbana-Campaign

- Policy Research Action Group (PRAG) - helping community groups acess university resources to address urban problems in Chicago

Grupos dentro de universidades americanas envolvidos com pesquisa-ação em problemas ambientais urbanos, com as comunidades locais

- Sharing Understanding of the HIV experience - participatory actionresearch envolving HIV-positive gay men

Dentro de Ciências Sociais/Sociologia, interessante utilização de pesquisa-ação envolvendo a questão da AIDS em grupos de risco (gays soropositivos)

AltaVista

Enorme número de sites de interesse contendo questões de action-research, participatory-research e participatory-actio-research. Cerca de 200 são mais diretamente relacionados. Devido ao grande número, não caberia aqui detalhes, mas apenas citar que incluem-se assuntos como:

- Home-pages de action-research de Universidades, principalmente americanas; http://imlab9.landarch.uiuc.edu/ eslarp/reports/main.html

- Textos básicos: história da action-research, fundamentos filosóficos/epistemológicos, tipologia;

http://www.cchs.su.edu.au/Academic/CH/teaching/AR/journal/PAR.html

- Revistas e Jornais sobre action-research; http://www.triangle.co.uk/ triangle/ear

- Redes de Trabalho (networks) de action-research em questões educacionais (PARnetparticipatory action-reseach, Collaborative Action Research Network, PRO-NETNational Action Research Network, ; 
http://www.otan.dni.casas/16OAR/16_Pronet.html

- Congressos Mundiais sobre action-research - como o que foi realizado em Cartagena (Colômbia) em junho de 1997

http://munex.arme.cornell.edu.PARnet/calendar/5june97/Auspices.htm

- Home-pages de pesquisadores interessados em intercâmbio de experiências em actionresearch;

http://educ.queensu.ca/projects/action research/karen.htm

- Simpósios internacionais de Collaborative Action Research;

http://munex.arme.cornell/PARnet/calendar/16april96.htm

São portanto informações que não se encontram disponíveis em nossas bibliotecas, e a possibilidade de intercâmbio com pessoas envolvidas em todo o mundo é uma oportunidade que não pode ser desprezada. Devemos tomar cuidado e sermos objetivos dentro desse oceano de informações disponíveis na Web, sob o risco de nos perdermos em meio a tantas possibilidades. 


\section{REFERÊNCIAS BIBLIOGRÁFICAS}

ALENCAR, E. Pesquisa Qualitativa:Roteiro de Aula. Lavras : Universidade Federal de Lavras, Departamento de Administração e Economia, 1996. 126 p.

ARDOINO, J. Abordagem Multireferencial (Plural) das situações educativas e formativas. In: Joaquim Gonçalves Barbosa. Multirrenferencialidade nas ciências e na educação. São Carlos: EdUFSCar, 1998. p. 24-41.

BARBOSA, J.G. Posfácio. In: Joaquim Gonçalves Barbosa. Multirrenferencialidade nas ciências e na educação. São Carlos: EdUFSCar, 1998. p. 200-205.

BERNARDES,E. \& NANNE, K. O Brasil organizado funciona. Revista Veja, p. 7077, Fev.1994.

BONILA, V. D.; CASTILLO, G.; FALS BORDA, O; LIBREROS, A . Causa popular, ciência popular: Uma Metodologia do conhecimento científico através da ação. In: Carlos Rodrigues Brandão: Repensando a Pesquisa Participante. São Paulo: Editora Brasiliense, 1984. $6^{\circ}$ ed. p. 131-157.

BORDENAVE, J..E.D. O que é participação. $3^{\circ}$ ed. São Paulo: Editora Brasiliense, 1985. 86 p. (Coleção Primeiros Passos)

CRESPO, S. \& e LEITÃO, P. O que o Brasileiro pensa da Ecologia. Rio de Janeiro: MAST-1993. Museu de Astronomia e Ciências Afins/CNPq, CETEM-Centro de Tecnologia Mineira/CNPq, ISER-Instituto de Estudos da Religião. 255 p.

CRUZEIRO DO SUL. Jornal. Reportagens 90-98

DAMÁZIO, A . Entupindo. Votorantim: Folha Corrida - Ação Cultural Botura-ti, s..d. 
DEMO, P. Pesquisa e Construção do Conhecimento - Metodologia Científica a Caminho de Habermas. Rio de Janeiro: Editora Tempo Brasileiro, 1994. 126 p.

DEMO, P. . Elementos metodológicos da pesquisa participante. In: Carlos Rodrigues Brandão: Repensando a Pesquisa Participante. São Paulo: Editora Brasiliense, 1984. cap. 5. p. 104-130.

ESTEVES, A. J.. A Investigação-acção. In: SILVA, A . S. \& PINTO, J.M : Metodologia das Ciências Sociais. Portugal , Editora Afrontamento, 1987. p. 251278

FALS BORDA, O. Aspectos Teóricos da Pesquisa Participante: considerações sobre o significado e o papel da ciência na participação popular. In: Carlos Rodrugues Brandão: Pesquisa Participante. São Paulo ,Editora Brasiliense,.1981. $6^{\circ}$ Edição. p. $42-62$

FERREIRA, L. A Questão Ambiental - Sustentabilidade e Políticas Públicas no Brasil. São Paulo: Editora Boitempo, 1998. 153 p.

FERREIRA, L. Os fantasmas do Vale (Representações e Modos de Ação Social em Cubatão, SP). Campinas,1991. 213 p. Dissertação de Mestrado - Universidade Estadual de Campinas.

FOLHA DE VOTORANTIM . $31^{\circ}$ Aniversário da Emancipação. Votorantim, 08. dez. 94. 120 p. Suplemento, 1

FOLHA DE VOTORANTIM . $32^{\circ}$ Aniversário da Emancipação. Votorantim, 08. dez. 95.92 p. Suplemento, 1 
FOLHA DE VOTORANTIM. Reportagens, anos 78-98.

FÓRUM INTERNACIONAL DE ONG's E MOVIMENTOS SOCIAIS. Tratados das ONGs. Rio de Janeiro, 1992 : Instituto de Ecologia e Desenvolvimento.264 p.

FREIRE, P. Criando Métodos de Pesquisa Alternativa: aprendendo a fazê-lo melhor através da ação. In: Carlos Rodrigues Brandão: Pesquisa Participante. São Paulo, Editora Brasiliense, 1981. p. 34-41.

GRUPO ECOLÓGICO CASCATA BRANCA. Relatório Anual de Atividades./ Apresentada a Delegacia de Ensino de Votorantim, 1990.. 3 p.

GRUPO ECOLÓGICO CASCATA BRANCA. Proposta aos Candidatos a Prefeito de Votorantim, 1992. Votorantim. $06 \mathrm{p}$.

KUCHELMEISTER, G. \& BRAATZ, S . Urban Forestry Revisited, Unasylva, vol.44, n 173, p. 3-12, 1993

LAPASSADE, G. Da multirreferencialidade como "bricolagem". In: Joaquim Gonçalves Barbosa. Multirrenferencialidade nas ciências e na educação. São Carlos: EdUFSCar, 1998. p. 126-148

MASP. Miguel Dutra - o poliédrico artista paulista. São Paulo: MASP, 1981. 111 p.

McCORNICK, J. Rumo ao Paraíso: a história do movimento ambientalista. São Paulo: Editora Saraiva, 1992. 224 p. 
MELO, A . L. P. \& MEIRA, M.T. Levantamento das Áreas Verdes de Piracicaba e Proposta de Implantação com Participação da População. In: I REUNIÃO PAULISTA DE INICIAÇÃO CIENTÍFICA EM CIÊNCIAS AGRÁRIAS e IV CONGRESSO DE INICIAÇÃo CIENTÍFICA DA ESALQ. Anais. Piracicaba: Centro Acadêmico "Luiz de Queiroz", 1989. p. 22.

MELO, A . L.P.\& GOMES, L.J. Sensibilidade Ambiental X Desinteresse. Folha de Votorantim, p.02, 22/fev/91.

MELO, A . L. P. Proposta de Implantação do Parque Municipal da Cachoeira de Votorantim com Participação da População (Proposta de Projeto). Votorantim, 1991. $35 \mathrm{p}$.

MELO, A . L. P. Plano de Trabalho-Princípios Básicos. Votorantim, 1993. 10 p.

MELO, A . L.. P. Proposta de Estruturação da Área de Meio Ambiente da Prefeitura de Votorantim, 1997, $25 \mathrm{p}$.

MENEZES, C.L. Emergência e evolução da política ambiental urbana no Brasil: do Estado Nono à Nova República. Revista de Administração Pública, vol. 31, nº 01, p. 70-95, jan/fev. 1997

MORIN, E. O Método I - A Natureza da Natureza. Lisboa: Mem-Martins, EuropaAmérica, 1987, $353 \mathrm{p}$.

OLIVEIRA, R. D. \& OLIVEIRA, M. D.. Pesquisa Social e Ação Educativa: conhecer a realidade para poder transformá-la. In: Carlos Rodrigues Brandão : Pesquisa Participante. São Paulo:Editora Brasiliense . p. 17-33.

PLANO DE GOVERNO. João Souto Neto/PSDB. 1996, 10 p. 
PRIGOGYNE, I. \& STENGERS, I. A Nova Aliança. Lisboa: Editora Lisboa Gradiva, s.d. $401 \mathrm{p}$.

PROMOHAB (Secretaria Municipal de Promoção Social e Habitação-Prefeitura Municipal de Votorantim). Cadastro de Áreas Verdes de Votorantim. 31 p. 1993.

SAINT-HILAIRE, A . Viagem à Província de São Paulo. São Paulo: Editora ItatiaiaEdusp, 1976. 227 p. (Série Reconquista do Brasil, v. 18)

SÃO PAULO (Estado). Secretaria de Meio Ambiente. Coordenadoria de Educação Ambiental. Meio Ambiente e Desenvolvimento - Documentos Oficiais, Organizações Não-Governamentais. São Paulo, 1993. 24 p. (Série Documentos)

SÃo PAULO (Estado). Secretaria do Estado de Meio Ambiente - Secretaria de Planejamento e Gestão - Fundação Prefeito Faria Lima-CEPAM. Política Municipal de Meio Ambiente - Orientação para os Municípios. São Paulo, 1992. 167 p.

SATO, M. \& SANTOS, J.E. Agenda 21 em Sinopse. Universidade Federal de São Carlos, Programa de Pós-Graduação em Ecologia e Recursos Naturais. São Carlos, . 1996. $42 \mathrm{p}$.

SORRENTINO, M.; MELO, A .L.P.; BARSELERI, R.C.D. \& IMAMOTO, M. Educação Ambiental-Extensão Universitária: : Uma experiência em Escola Pública de $1^{\circ} \mathrm{Grau}$. In: $6^{\circ}$ CONGRESSO FLORESTAL BRASILEIRO, Campos do Jordão, 1990. Anais. Campos do Jordão: SBS-SBEF, 1990, p. 204-215.

SORRENTINO, M. Associação para Proteção Ambiental de São Carlos: subsídios para compreensão das relações entre movimento ecológico e educação. São Carlos, 1988, 288 p. Dissertação Mestrado. 1988. Universidade Federal de São Carlos 
SORRENTINO, M. Educação Ambiental: Avaliação de Experiências Recentes e suas Perspectivas. Piracicaba, 1995. Departamento de Ciências Florestais da ESALQ/USP. $64 \mathrm{p}$.

THIOLLENT, M. Notas para o debate sobre pesquisa-ação. In: Carlos Rodrigues Brandão: Repensando a Pesquisa Participante. São Paulo,Editora Brasiliense, 1984. p. 82-103.

THIOLLENT, M.J.M. Metodologia da Pesquisa-Ação. São Paulo: Cortez Editores Associados, 1985. $108 \mathrm{p}$.

TRIVIÑOS, A.N.S. Introdução à Pesquisa em Ciências Sociais-a Pesquisa Qualitativa em Educação. São Paulo: Editora Atlas, 1992. 177 p.

TSE-TUNG, M.. Sobre a prática (sobre a relação entre o conhecimento e a práticaA relação entre conhecer e agir). Belém: Editora Boitempo, 1979 . p. 67-83.

VIEIRA, L. \& BREDARIOL, C. Cidadania e Política Ambiental. Rio de Janeiro: Editora Record, 1998. 171 p.

VIOLA, E. O movimento ambientalista no Brasil (1971-1991): da denúncia e conscientização pública para a institucionalização e o desenvolvimento sustentável. In: GOLDENBERG.M. Ecologia, Ciência e Política. Rio de Janeiro: Editora REVAM, 1992. p. 49-73.

VOTORANTIM (Governo Municipal). Plano Diretor de Desenvolvimento Integrado. Parte A-Análise do Sítio Urbano, 1986. 123 p.

VOTORANTIM (Governo Municipal). Dados sobre o município, 1996. 98 p 
WHITESIDE, M. Diagnóstico (Participativo) Rápido Rural - Manual de Técnicas. , Moçambique: Comissão Nacional de Meio Ambiente, 1994. 64 p. 